\title{
A Middle Pennsylvanian (early Asturian) tropical dry forest, Atokan- Desmoinesian boundary, Illinois Basin, USA
}

\author{
William A. DIMICHELE ${ }^{1 *}$, Arden R. BASHFORTH ${ }^{1,2}$, Cortland F. EBLE $^{3} \&$ W. John NELSON ${ }^{4}$
}

\author{
${ }^{1}$ Department of Paleobiology, National Museum of Natural History, Smithsonian Institution, Washington, DC 20560, USA; \\ dimichel@si.edu \\ ${ }^{2}$ Natural History Museum of Denmark, University of Copenhagen, Øster Voldgade 5-7, 1350 Copenhagen K, Denmark; \\ bashforth@snm.ku.dk \\ ${ }^{3}$ Kentucky Geological Survey, 247D Mining and Mineral Resources Bldg., University of Kentucky, Lexington, Kentucky \\ 40506-0107, USA; eble@uky.edu \\ ${ }^{4}$ Illinois State Geological Survey, University of Illinois at Urbana-Champaign, 615 East Peabody Drive, Champaign, IL 61820, \\ USA; jnnelson@illinois.edu \\ * Corresponding author
}

DiMichele, W.A., Bashforth, A.R., Eble, C.F. \& Nelson, W.J. 2016. A Middle Pennsylvanian (early Asturian) tropical dry forest, Atokan-Desmoinesian boundary, Illinois Basin, USA. [Un bosque tropical seco del Pensilvánico Medio (Asturiense inferior), límite Atokan-Desmoinesian, Cuenca de Illinois, Estados Unidos]. Spanish Journal of Palaeontology, 31 (1), $41-84$.

Manuscript received 02 November 2015

Manuscript accepted 03 April 2016

(C) Sociedad Española de Paleontología ISSN 2255-0550

\section{ABSTRACT}

Six late Atokan (early Asturian) floras from seasonally dry environments are described and quantitatively analyzed from adpressions and palynomorphs. Collections are from the eastern margin of the Illinois Basin, USA, in an $80 \mathrm{~km}$ $\mathrm{N}-\mathrm{S}$ transect. Plant fossils occur in sedimentary rocks below the underclay (paleosol) of the Minshall-Buffaloville Coal Member (thus, not "roof-shale" assemblages), uppermost Brazil Formation. Growth of floras under seasonal dryness is indicated by outcrop and lithological features that suggest deposition in flashy discharge streams, including intraformational conglomerates, plant fossils that cross bedding planes indicating rapid, episodic burial, and local rhythmically laminated sediments. Common charcoal clasts are consistent with seasonal climate. Cordaitalean foliage dominates the macroflora, accompanied by the dryland elements Lesleya sp., Taeniopteris sp. cf. T. multinervia, and Sphenopteridium sp. Two unusual forms of foliage are presumed to be rare or novel dryland species. Small numbers
RESUMEN

Se describen seis asociaciones de floras del Atokiense alto (Asturiense inferior) de ambientes estacionalmente secos, analizando cuantitativamente tanto las adpresiones como los palinomorfos. Las colecciones proceden del borde este de la Cuenca de Illinois, Estados Unidos, en un corte transversal N-S de $80 \mathrm{~km}$. Los fósiles aparecen en rocas sedimentarias situadas por debajo del suelo de vegetación del Minshall-Buffaloville Coal Member (no son, por tanto, asociaciones a techo del carbón) en la parte más alta de la Formación Brazil. El desarrollo de floras bajo condiciones de sequedad estacional viene dado por rasgos litológicos y del afloramiento que sugieren un depósito por corrientes de descarga fuerte ocasional, como serían los conglomerados intraformacionales, los restos vegetales depositados a ángulo cruzado con los planos de estratificación por un enterramiento rápido y episódico y, localmente, sedimentos laminados rítmicamente. La presencia frecuente de clastos de carbón es congruente con un clima estacional. Las hojas de 
of wetland/periwetland taxa include calamitaleans, Linopteris neuropteroides, Karinopteris/Eusphenopteris sp., marattialean fern foliage, Senftenbergia plumosa, cf. Zeilleria avoldensis and Sphenopteris sp. The palynoflora is dominated by marattialean tree ferns, wetland plants with broad dispersal capacities and environmental tolerances. Subdominant elements also have strong wetland affinities: arborescent lycopsids, calamitaleans, and small ferns. Cordaitalean pollen is relatively uncommon. Palynoflora-macroflora mismatches may reflect primary ecology, palynomorph reworking, or both. The occurrence of these floras near the Atokan-Desmoinesian ( $\sim$ Bolsovian-Asturian) boundary coincides with an array of physical and geochemical data that indicate change from weak rainfall seasonality to marked seasonality at all phases of glacial-interglacial cycles, reflected prominently in the stratigraphic record from the localities studied.

Keywords: dryland flora, upland flora, palynology, paleoecology, climate.
Cordaitales dominan la macroflora, junto con elementos de ambientes más secos como Lesleya sp., Taeniopteris sp. cf. $T$. multinervia y Sphenopteridum sp. Se supone que dos formas poco corrientes de hojas son especies raras o nuevas. También aparecen en pequeña cantidad taxones de áreas pantanosas/ semi-pantanosas como calamitales, Linopteris neuropteroides, Karinopteris/Eusphenopteris sp., restos de fronde de maratiales, Senftenbergia plumosa, cf. Zeilleria avoldensis y Sphenopteris sp. La palinoflora está dominada por maratiales arbóreas, que son plantas de zonas húmedas con una amplia capacidad de dispersión y alta tolerancia medioambiental. Los elementos subdominantes también tienen una fuerte afinidad pantanosa: licópsidas arbóreas, calamitales y helechos pequeños. El polen de cordaitales es poco frecuente. Las diferencias que se observan entre el contenido de microflora y macroflora podrían reflejar la ecología, un retrabajado de los palinomorfos, o ambos. La presencia de estas floras cerca del límite Atokiense-Desmoinesiense ( Bolsoviense-Asturiense) coincide con una gran cantidad de datos físicos y geoquímicos que indican un cambio de precipitaciones estacionales débiles a una marcada estacionalidad en todas las fases de los ciclos glaciares-interglaciares, como se refleja de manera clara en el registro estratigráfico de las localidades estudiadas.

Palabras clave: flora de ambiente seco, flora de áreas drenadas, palinología, paleoecología, clima.

\section{INTRODUCTION}

A major environmental change occurred in the equatorial lowlands of Pangea during the middle part of the Middle Pennsylvanian. High and equitably distributed tropical rainfall changed abruptly to a pattern of increased rainfall seasonality during all phases of the glacioeustatic and climatic cycles that strongly overprinted this time in Earth history (Cecil et al., 1985; Tabor \& Poulsen, 2008; Tabor et al., 2013b). Stratigraphically, this event took place in the late Moscovian, near the Atokan-Desmoinesian Stage boundary of the USA, which is broadly coeval with (Peppers, 1996) but lies just above the Bolsovian-Asturian Substage boundary of western Europe (Bashforth \& Nelson, 2015; Bashforth et al., 2016a). The event is marked by major changes in the geochemistry and character of coal deposits (Cecil et al., 1985; Cecil, 1990), in the character of fluvial siliciclastic rocks (Bertier et al., 2008), and by widespread and often profound shifts in vegetational patterns (Phillips et al., 1985; Opluštil \& Cleal, 2007; van Hoof et al., 2013). Despite the dramatic physical and biotic modifications in tropical ecosystems at this time, the interval has not received the same degree of attention accorded the Middle-Late Pennsylvanian boundary, across which there was a major change from lycopsid- to treefern-dominated peat-forming wetlands (Phillips et al., 1974), accompanied by a general turnover of the wetland flora (DiMichele et al., 2001). Nonetheless, the precursor Middle Pennsylvanian event offers an excellent opportunity to study the effects of rapid environmental change on the tropical ecosystems of Pangea during the transition from icehouse to greenhouse conditions (Gastaldo et al., 1996).

In this paper, we describe several examples of floras collected from near the Atokan-Desmoinesian boundary, which witnessed climatic and associated vegetational change, focusing in particular on plant communities that thrived under seasonally dry conditions. These floras are uniformly dominated by cordaitalean gymnosperms, but also include plants atypical of contemporaneous wetland assemblages, such as the enigmatic seed plants Lesleya, Taeniopteris and Sphenopteridium. The assemblages also contain elements of wetland floras that persisted in all Pennsylvanian and early Permian landscapes where locally high groundwater tables were present: the marattialean tree ferns and calamitalean sphenopsids. Rare medullosan pteridosperms also may be present, but the macrofloral remains of lycopsids have not been observed. In contrast, palynological preparations from the same rocks that host the dry-forest macrofloral assemblages reveal floras dominated by tree ferns and lycopsids, rather than cordaitaleans and other enigmatic elements, a perplexing incongruence of a type that has received comment elsewhere (Opluštil et al., 2009b; Mander et al., 2010; Looy \& Hotton, 2014; Looy et al., 2014b). The inequality between palynological 
and macrofloral assemblages is taken a step further here, with conifer pollen being identified in one of the dryland assemblages, but also in shales that hosted a wetland flora from the roof of one of the coal beds in the study interval. The presence of wetland plants in dryland macrofloral assemblages may be explained by the existence of refugial pockets within the seasonally dry landscape, areas with persistently high water tables, such as stream and lakeside environments (DiMichele et al., 2006; Bashforth et al., 2014; Looy et al., 2014b); disproportionately high spore production by these pteridophytic plants would make them appear dominant in palynofloras. In contrast, the presence of conifer pollen in a wetland assemblage suggests not only the presence of such plants in proximity to the environment of deposition, but at least local conditions favorable to conifers. In the generally flat and extremely broad landscape of west-central Pangea, the presence of conifers points to the onset of seasonality sufficient to create landscape heterogeneity (DiMichele et al., 2010; Looy \& Hotton, 2014) within which plants intolerant of perennially high water tables could live.

All of the plant-fossil-bearing deposits reported here contain evidence of sediment accumulation under periodic, high-energy flow conditions, typical of seasonal climatic regimes (Fielding et al., 2009). The enclosing sedimentary rocks range from conglomerates to shales, often finely interbedded. Massive siltstones frequently contain plant remains at odd angles, as if rapidly deposited as part of the traction load within an active channel. Where beds are distinctly laminated, plant axes and leaves may cross-cut laminae at steep angles, again implying rapid sediment accumulation, probably in discrete pulses. In rare instances, multiple sets of thick laminae that fine upwards from sandstone to siltstone may record the periodic introduction of sediment-laden plumes into standing bodies of water, perhaps abandoned channels. In one instance, macrofossils were found in a paleoslump block incorporated into a channel fill beneath the underclay of a coal bed. As such, taphonomic aspects of the specimens, together with examinations of mine-face exposures in the field, collectively point to the preservation of plant communities that prevailed under a regime of seasonal precipitation, most likely in a sub-humid climate (sensu Cecil, 2003).

\section{GEOLOGICAL SETTING}

\subsection{Study localities}

Plant fossils included in this study come from the eastern margin of the Illinois (Eastern Interior) Basin of the USA (Fig. 1). They were collected from six surface coal mines, two each in three contiguous counties (from north to south: Clay, Greene and Daviess) in the central to southern part of western Indiana (Fig. 2), representing a linear distance of approximately $80 \mathrm{~km}$ (50 miles). All mines are presently closed and the collecting areas no longer accessible due to surface reclamation; operator names are those used at the time of collecting. Geographic coordinates of the mines are as follows:

Clay County: (1) Brazil Coal and Clay Company, Saline Pit No. 1 (collected in 1988), located in 1993 near the northeast corner of the Saline City $7.5^{\prime}$ quadrangle, NW ${ }^{1 / 4}$
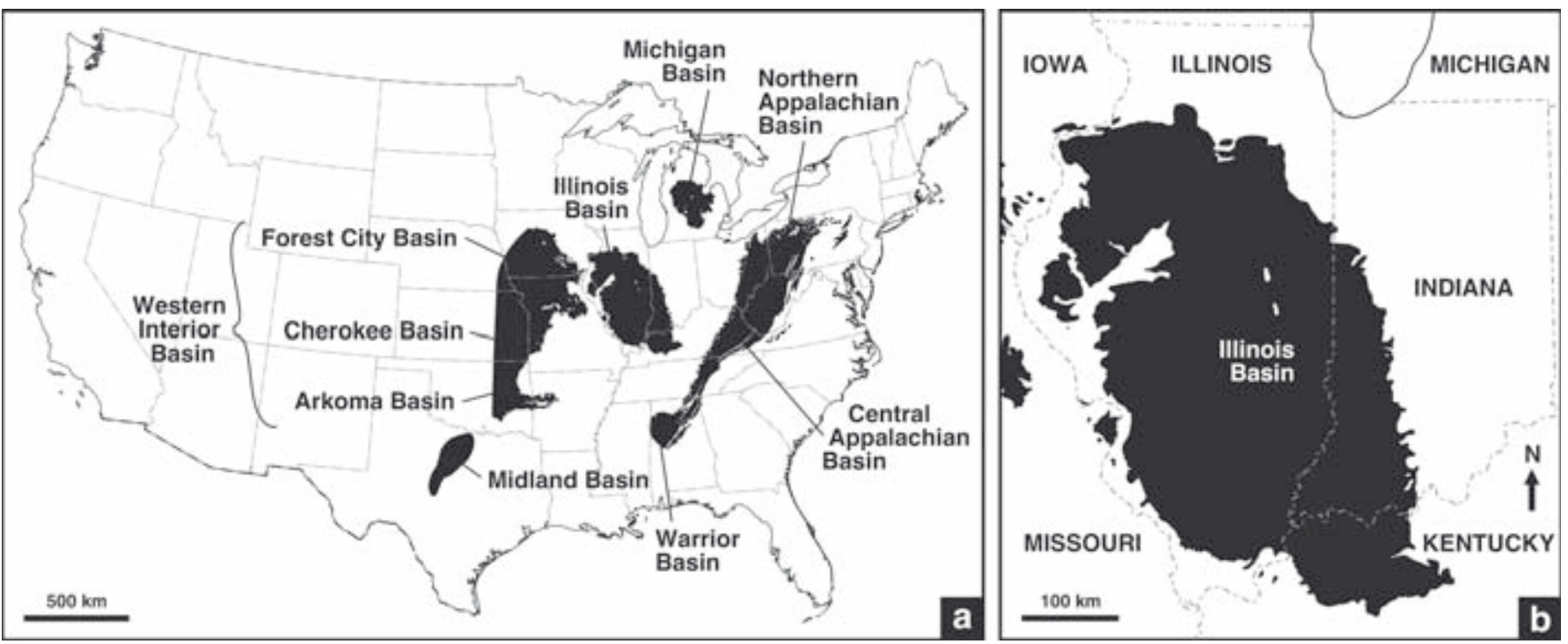

Figure 1. Geography of sample locations. a) Major Pennsylvanian-age coal basins of the United States, showing location of the Illinois Basin, source of the study samples. b) Detail of the Illinois Basin. 


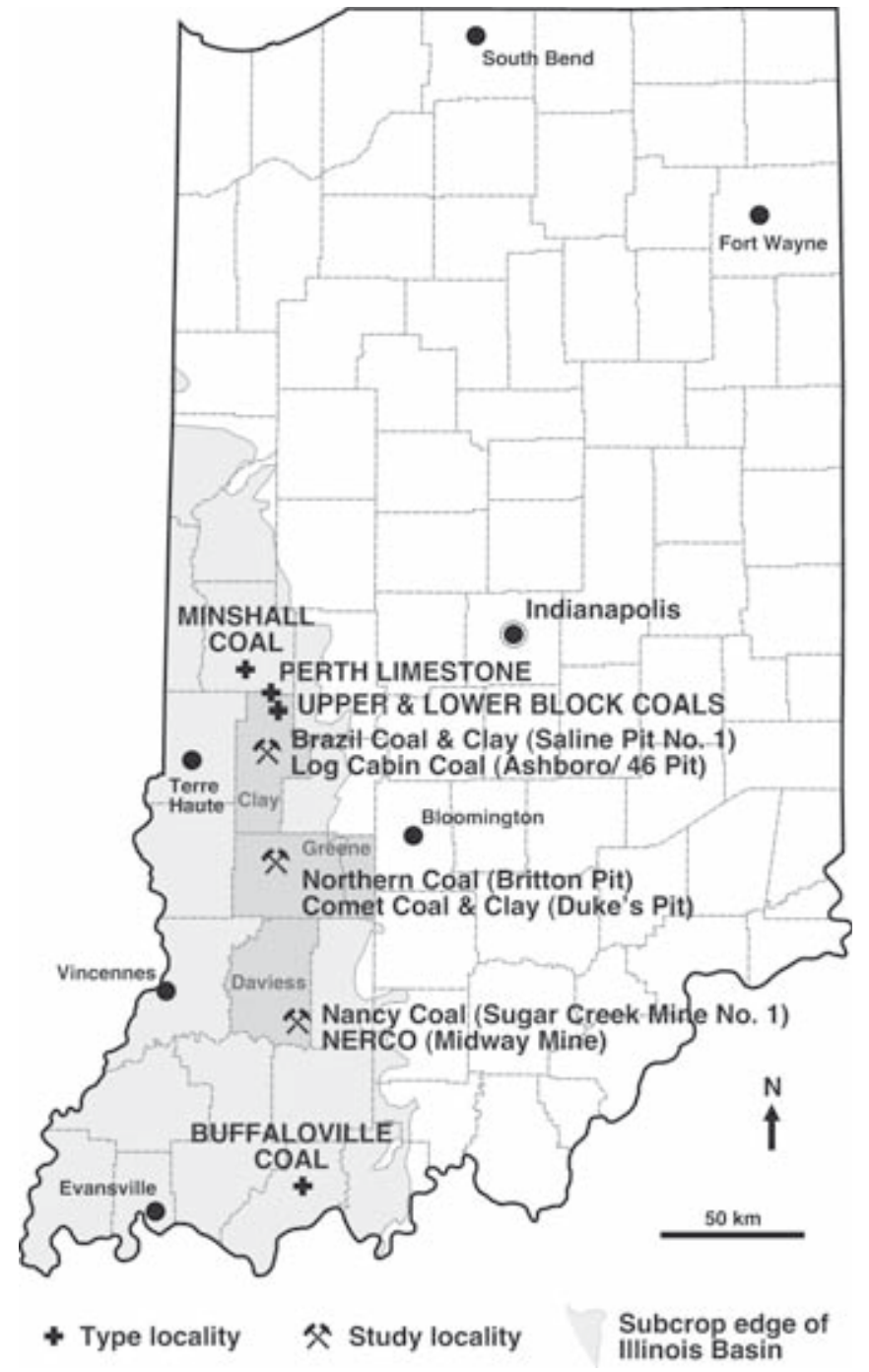

Figure 2. Location of sample localities in the eastern Illinois Basin. Basin is outlined in gray. The counties in which localities occur are shaded more darkly. See text for details on location of sampling sites and type localities of stratigraphic units mentioned.

NW $1 \frac{1}{4}$ of Section 30, T11N, R6W; and (2) Log Cabin Coal Company, Ashboro/46 Pit (collected in 1980), located on the Center Point 7.5' quadrangle, SW $1 / 4$ SE $1 / 4$ of Sec. 17, T11N, R6W. The Log Cabin mine was 2.5-3.2 km (1.52.0 miles) northeast of the Brazil Coal and Clay mine.

Greene County: (1) Northern Coal Company, Britton Pit (collected in 1993), located on the Switz City 7.5' quadrangle, SE $1 / 4 \mathrm{NE}^{1 / 4} \mathrm{NE}^{1 / 4}$, Sec. 3, T7N, R6W; and (2) Comet Coal and Clay Company, Duke's Pit (collected in 1984), at the time being mined by York Excavating Company, also located on the Switz City 7.5' quadrangle, $\mathrm{SE}^{1 / 4} \mathrm{NE}^{1 / 4}$ of Sec. 2, T7N, R6W, less than $1.6 \mathrm{~km}$ (1 mile) east of the Britton Pit.

Daviess County: (1) Nancy Coal Company, Sugar Creek Mine No. 1 (collected in 1980), located in the SE $1 / 4$
$\mathrm{NW}^{1 / 4}$ and SW $1 / 4$ NE $1 / 4$ of Section 20, T2N, R5W, on the Alfordsville 7.5' quadrangle; and (2) NERCO, Midway Mine (collected in 1988) on the Loogootee 7.5' quadrangle, $\mathrm{NW}^{1 / 1} / 4 \mathrm{NW}^{1 / 4}$ of Sec. 5 , T2N, R5W.

\subsection{Geology of the collecting localities}

\subsubsection{Stratigraphy}

Plant fossils described in this study were collected from siliciclastic rocks situated beneath a coal bed that typically is split by a claystone layer in its middle to lower parts, and above a coal identified as the Upper Block Coal Member (Fig. 3). Thin, discontinuous coaly streaks or dirty coals may exist in the succession between these thicker, more continuous coals. In Clay and Greene counties, the upper coal can be identified confidently as the Minshall Coal Member, the type section of which is in Parke County immediately north of the study area (Fig. 2). The Minshall Coal is the first major coal above the Lower Block - Upper Block couplet, and is overlain by the lenticular, marine Perth Limestone, the type section of which is in Clay County (Fig. 2), the northernmost county of the study area. At several exposures in Clay County, a claystone or shale layer, which ranges from a few $\mathrm{cm}$ to about $2 \mathrm{~m}$ thick, was observed in the middle to lower portion of the Minshall Coal.

There is less clarity about the name that should be applied to the coal above the plant-fossil-bearing strata in Daviess County, which mine operators have routinely identified as the Buffaloville Coal Member. However, the type section of the Buffaloville Coal is situated a considerable distance south of the study area, in Spencer County (Fig. 2). Furthermore, like the Minshall Coal in counties to the north, the Buffaloville Coal in the Daviess County study area is identified in the field as having a distinctive claystone layer, commonly 1 to $5 \mathrm{~cm}$ thick, near the middle of the bed, by its stratigraphic position above the Lower Block - Upper Block couplet, and by sometimes having a lenticular marine limestone in the overlying section. The conodont fauna retrieved from this limestone in Daviess County has been interpreted as equivalent to that of the Perth Limestone (P.H. Heckel, written communication to W.J. Nelson, July 15, 2013). Likewise, palynological analyses of the Buffaloville Coal in Daviess County (Eble, unpublished data) and the Minshall Coal in Clay and Greene counties (Bashforth et al., 2016a; Eble, unpublished data) all indicate assignment to the Radiizonates difformis (RD) spore assemblage zone of Peppers $(1985,1996)$. Both the Minshall Coal in Clay and Greene counties and the Buffaloville Coal in Daviess County are the youngest coals in the local stratigraphic succession to contain the diagnostic palynomorph $R$. difformis. 


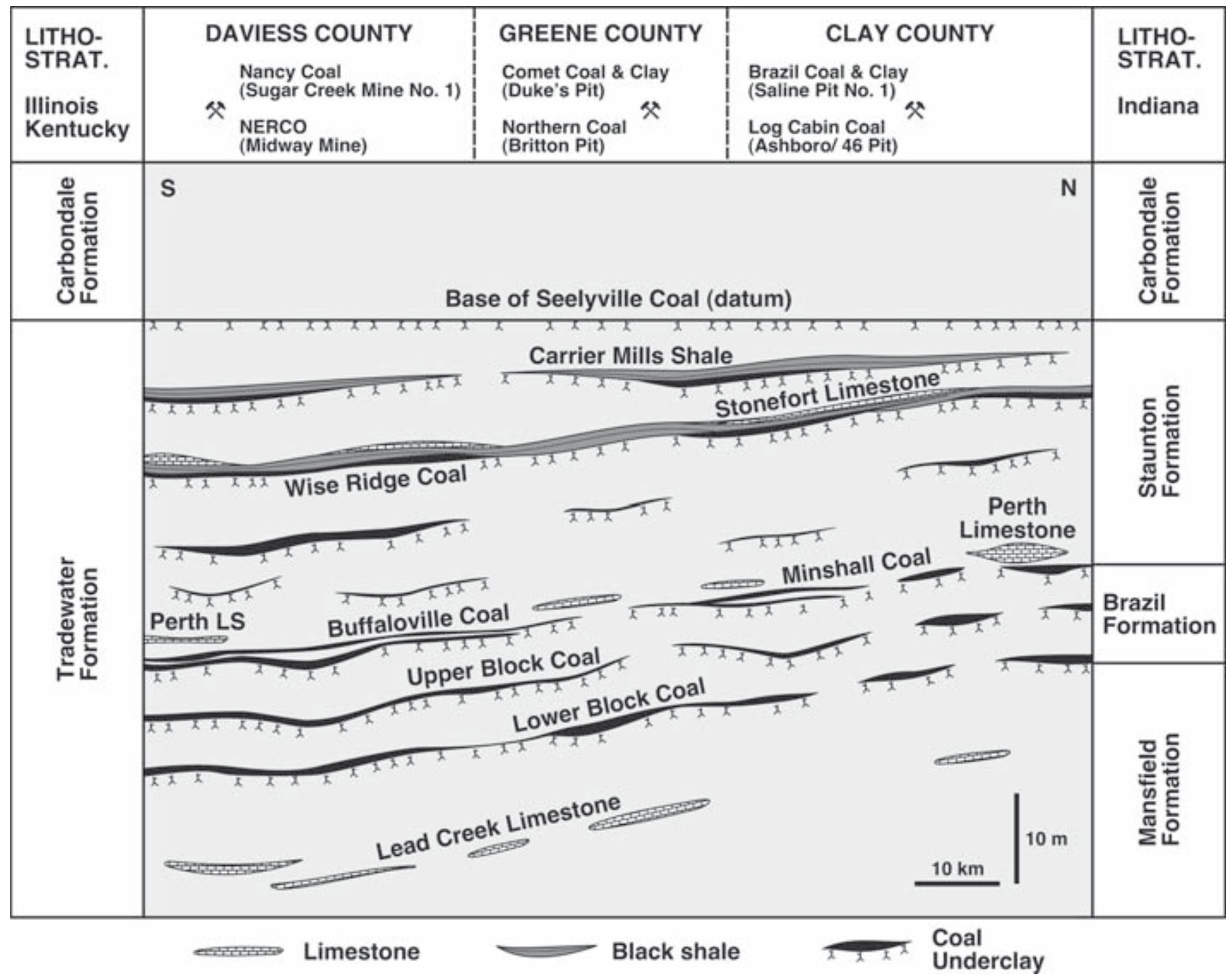

Figure 3. Lithostratigraphy of the study interval. The samples analyzed come from below the underclay of the Buffaloville-Minshall coal bed (see text for details). The one wetland palynological sample (Comet Coal \& Clay - Table 3; Fig. 16) comes from above the Buffaloville-Minshall coal bed. All limestones contain marine fossils.

The palynological studies of Peppers (1993, 1996) placed the Buffaloville Coal above both the Minshall Coal and Perth Limestone, in the succeeding Cadiospora magna-Mooreisporites inusitatus (MI) spore assemblage zone. However, the Illinois State Geological Survey recently acquired a test-hole core (UMI Buffaloville core), drilled $3.2 \mathrm{~km}$ south of the type section of the Buffaloville Coal in Spencer County. The Buffaloville Coal is clearly identifiable in the core, being the target of mining and exploration in the area, and is directly overlain by a marine limestone. Petrographic and palynological analyses of the coal in the UMI Buffaloville core indicate assignment to the $R$. difformis $(\mathrm{RD})$ zone (Eble, unpublished data), thus paralleling analyses of the Buffaloville coal in Daviess County. These data are inconsistent with Peppers' (1993,
1996) placement of the Buffaloville Coal in the overlying C. magna-M. inusitatus (MI) zone, and we question whether the two samples of "Buffaloville Coal" analyzed by Peppers (1993) actually represent this coal. Peppers (1993) noted that one sample consisted of loose coal fragments from the spoils of an abandoned strip mine, whereas the other was collected from coal in place at an inactive surface mine, but without stratigraphic data.

To complicate matters further, the conodont fauna retrieved from the marine limestone above the Buffaloville Coal in the UMI Buffaloville core includes forms characteristic of the Perth Limestone, and also the Seville Limestone of northwestern Illinois and the Curlew Limestone of western Kentucky. However, this sample also contains conodonts that suggest the limestone could 
be slightly younger than the Perth (P.H. Heckel, written communication to W.J. Nelson, August 5, 2011 and August 11, 2014). Thus, although the palynological and conodont data are generally compatible, the conodonts allow for a slightly younger age than the spores.

Based on the biostratigraphic framework proposed by Peppers $(1985,1996)$, spore and pollen data from the Minshall and Buffaloville coals are indicative of a latest Atokan age, which he equated with the latest Bolsovian. However, palynological assemblages in clastic rocks from directly below the Minshall Coal contain rare taxa that are indicative of the Desmoinesian (which he equated with the Asturian), including Thymospora pseudothiessenii, Thymospora obscura, Cadiospora magna and Murospora kosankei (see Section 4 below). These Asturian forms apparently occur earlier in clastic rocks than in coal, and their association with palynomorphs typical of the late Bolsovian $R$. difformis (RD) zone reveals a degree of overlap between younger and older spore zones. These new palynological data indicate that the Minshall Buffaloville Coal may be of early Asturian age, rather than the latest Bolsovian age previously considered by Peppers $(1985,1996)$. An early Asturian age is consistent with biostratigraphic analyses of macrofloral assemblages associated with the Minshall Coal (Bashforth et al., 2016a, b) and the correlative Rock Island Coal Member in northwestern Illinois (Bashforth \& Nelson, 2015).

As a consequence of the information discussed above, we conclude that the Minshall Coal in Clay and Greene counties is the same coal as the so-called Buffaloville Coal in Daviess County (see also Mastalerz et al., 2003). Nonetheless, some ambiguity remains about correlation of the type Buffaloville and type Minshall coals - the type Buffaloville could be slightly younger than the Minshall. Based on palynological assemblages in the coals and associated clastic rocks, a strong case can be made for identity. However, the conodont faunas in the limestones overlying these coals in the study area, versus that above the Buffaloville Coal in its type area, are not in conformance. On the whole, the new palynological data from clastic strata associated with the coals more closely conform to the age assessment based on conodont data. It also remains possible that, given the spatio-temporal gaps that exist in terrestrial and marginal marine successions (Miall, 2014; Scott \& Stephens, 2014), the limestones above the coals may be separate units, whereas the underlying coals record the same episode of peat accumulation.

Clay County. Coals exposed in the Brazil Coal and Clay, Saline Pit No. 1 and Log Cabin Coal Company, Ashboro/46 Pit can be confidently identified as the Lower Block, Upper Block, and Minshall coals. Exposed only in the Ashboro/46 Pit, the Lower Block Coal was more than $0.6 \mathrm{~m}$ (2 feet) thick and composed of dull-banded or "splint" coal. The Upper Block Coal, which was exposed in both mines and also in several nearby mines, varied from 0.6-0.9 m (2-3 feet) thick, and also was a hard, dull-banded "splint" coal that separated into large cubic blocks bounded by vertical joint planes at right angles. This attribute gave the Block coals their name in the type area northeast of Brazil, Indiana. The Minshall Coal ranged from 0.2-0.6 m (0.5-1.9 feet) thick and lay 7.6-15.2 $\mathrm{m}$ (25-50 feet) above the Upper Block Coal. The Perth Limestone was 1.5-3.0 m (5-10 feet above) the Minshall Coal in these mines. The presence of a limestone confirms the identity of the coals, because no limestone is associated regionally with the Block coals.

The Minshall Coal was $15 \mathrm{~cm}$ (6 inches) thick in the Brazil Coal and Clay Saline No. 1 Pit (labeled MC in Fig. 4), and the succession below the coal was complex and laterally variable. A package of rhythmically laminated fine-grained clastic rocks, coarsening upward from fine clayey siltstone to sandstone, occurred above the Upper Block Coal. This unit was mostly overlain, in irregular erosional contact, by a poorly to irregularly bedded sandy siltstone. This siltstone unit reached a maximum thickness of $1.7 \mathrm{~m}$ (5.5 feet), and varied laterally in thickness, locally nearly pinching out, and also varied in character, consisting in places of a series of en echelon, angularly disposed beds of sandstone, suggestive of formation by lateral accretion in a channel (point?) bar. This plant-fossil-bearing siltstone is the presumed source of the flora (labeled Pnts in Fig. 4) described from this mine, which was collected from spoils. The fossiliferous unit was altered in its uppermost part into a paleosol underclay, which either lay directly beneath the Minshall Coal, or beneath a thin carbonaceous shale bed that was separated from the Minshall Coal by an interval of silty shale; such vagaries reflect the lateral variability of

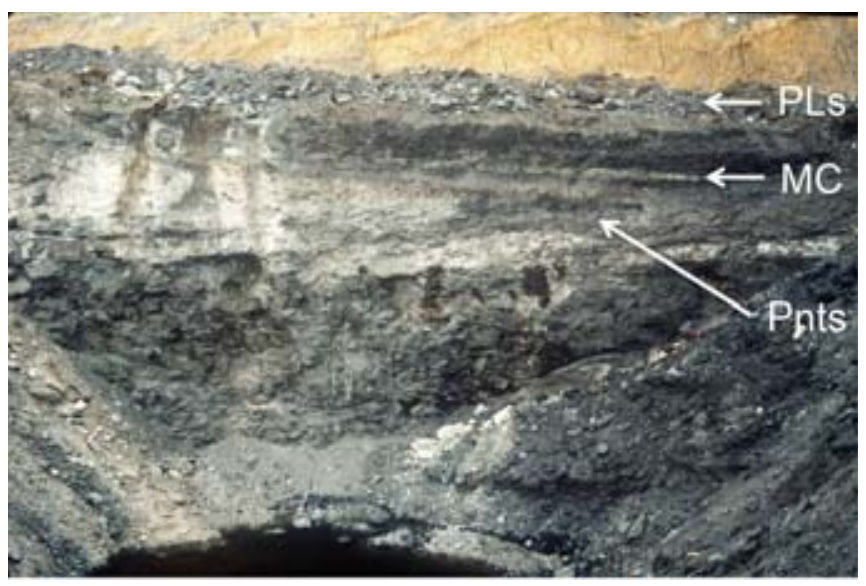

Figure 4. Stratigraphic section below the Perth Limestone (PLs) and above the Upper Block Coal Member (base of section, at waterline). Plant fossils (Pnts) were derived from below the Minshall Coal Member (MC) and its underclay in shales immediately above a series of en echelon sand bodies. Brazil Coal and Clay, Saline Pit No. 1, in 1988. 
the strata immediately below the coal. Above the Minshall Coal were 1.5-2.4 m (5-8 feet) of dark gray, silty shale that coarsened upward and contained no plant fossils. A $1.2 \mathrm{~m}$ (4 foot) thick limestone that contained marine invertebrate fossils, probably the Perth Limestone, occurred above the shale (labeled PLs in Fig. 4).

Bashforth et al. (2016a, b) gave a detailed description of the exposed stratigraphic succession in the Log Cabin Coal Company, Ashboro/46 Pit. The plant fossils described herein were found in a heterolithic unit located directly beneath the paleosol ('underclay') of the Minshall Coal, which was $15 \mathrm{~cm}$ thick in this mine (Bashforth et al., 2016b). The fossiliferous unit was c. $45 \mathrm{~cm}$ thick and consisted of irregular interbeds of medium gray siltstone and light gray, very fine- to fine-grained sandstone, with intercalated laminae of thin, dark gray shale. Some coarser grained beds are ripple cross-laminated, and horizons of granule- to pebble-size, subangular to subrounded, intraformational clasts (claystone, shale, siderite? nodules) are common. Immediately below the plant-fossil-bearing beds was a laterally extensive unit that varied from sandy dolomite or limestone to calcareous siltstone. Beneath this was a bioturbated siltstone that contained trace fossils similar to Conostichus and Teichichnus, suggesting an origin under restricted-marine to brackish conditions. Above the Minshall Coal, several compositionally distinct wetland plant assemblages were found in variegated shales up to $0.5 \mathrm{~m}$ thick (Bashforth et al., 2016a).

Greene County. Identification of the strata in Greene County is less certain than in Clay County, but three coal beds were exposed in both the Northern Coal Company, Britton Pit and the Comet Coal and Clay Company, Duke's Pit. These coals were probably the Lower Block, Upper Block, and Minshall coals based on correlation with several nearby mines and two continuously cored Indiana Geological Survey boreholes. In addition, the Britton Pit mine operator identified the lowest coal, which was up to $1.4 \mathrm{~m}$ (4.5 feet) thick and contained less than $2 \%$ sulfur, as the Lower Block Coal; in Greene and Daviess Counties, the Lower Block Coal consistently has a lowsulfur content. The Upper Block Coal, 7.6-9.1 m (25-30 feet) above the Lower Block Coal, was less than $0.3 \mathrm{~m}$ (1 foot) thick and contained numerous shale or "bone coal" layers. The upper coal, 0.2-0.5 m (0.8-1.7 feet) thick, had high sulfur content, typical for the Minshall Coal (Mastalerz et al., 2003). The Perth Limestone was absent in these mines. The succession exposed above the Minshall Coal was thin and included sandstone with an erosive lower contact.

In the Northern Coal Company Britton Pit, the stratal succession was complex and stratigraphically ambiguous. The top of the section was marked by two thin coal beds, each about $0.4 \mathrm{~m}$ ( 1.5 feet) thick, separated by $1.5-1.8 \mathrm{~m}$ (5-6 feet) of irregularly laminated, gray silty shale.
Thin underclay paleosols underlaid each coal, and a typical wetland macrofloral assemblage was present in the intervening shales. We interpret these two coals as equivalent to the Minshall Coal in Clay County, with which this succession bears strong resemblance, particularly to exposures in the Brazil Coal and Coal Clay, Saline No. 1 Pit. Plant fossils described herein were collected from below the lower of the two thin coals, which was underlain by a $7.6 \mathrm{~m}$ ( $25 \mathrm{foot})$ thick interval dominated by laminated sandy shale. On one side of the visible exposure surface (the other side being covered), a heterolithic unit, which consisted of massive tabular to lenticular sandstone beds interspersed with lenses and horizons of rhythmically bedded siltstone and sandstone, filled an erosional scour into the laminated strata. On the eastern flank of this scour fill, where the erosional base was visible, bedding was distinctly angular and numerous large slickensided surfaces were present. Bedding throughout the unit was tilted to the west. Plant fossils were collected in situ from throughout this heterolithic unit, which may represent a slump block or channel margin. The upper surface of the fossiliferous unit was erosionally truncated and overlain by a few feet of siltstone, in which the paleosol underclay of the lower thin coal was developed. Strata below this channel-form feature were covered due to reclamation activities underway when the collection was made.

As with other exposures of this stratigraphic interval, those in the Comet Coal and Clay Duke's Pit were complex and the coals difficult to identify confidently. Nonetheless, the position of the flora described herein approximates that identified at all other exposures where compositionally similar assemblages were collected. Four coaly horizons were exposed in the pit, with one of the Block coals clearly being the mining target. The coal exposed at the base of the pit, which we interpret as the Upper Block Coal, was overlain by a rhythmite that coarsened upward from claystone to sandy siltstone, rich in plant fossils in its basal $1 \mathrm{~m}$. Above this was a thin zone of coaly streaks, overlain by a gray siltstone with abundant plant fossils. The siltstone was overlain by a "bone" coal with a high clay content, which was overlain by a highly fossiliferous gray shale that was laterally truncated by a sandstone with an erosional base. The fourth (highest) coal, which we believe to represent the Minshall Coal, was thin and overlain by a rhythmically laminated, coarsening upward shale. This gray shale was truncated laterally by a sandstone body with an erosional base, immediately above which was a conglomeratic lag with pebble-sized clasts. Plant fossils were collected from spoils that had been removed from strata exposed near the top of the mine highwall. As such, the fossils described herein are either from the uppermost, channel-form pebbly sandstone body, or more probably, from the lenticular sandstone body below the uppermost exposed coal bed, which we interpret as the Minshall Coal. The assemblage is small due to difficult collecting 
conditions and time constraints enforced by the mine operator, but is nonetheless diverse and of significant taxonomic composition.

Daviess County. Coals mined at the Nancy Coal Company, Sugar Creek Mine No. 1 and the NERCO Midway Mine were, as reported by the mine operators, the Lower Block, Upper Block, Buffaloville, and unnamed Staunton Formation coals. These names are used consistently in Daviess County, but identity with the type Block and Buffaloville coals has not been established. The roof-shale lithologies immediately above the so-called Lower and Upper Block coals are consistently rhythmitic and coarsen upward from clayey shales to siltstones and sandstones. This type of roof rock also is seen above the so-called Buffaloville Coal at some locations. However, examination of geological descriptions made from the 1980s though 2015 in mines in Daviess County shows this interval to be highly variable and often lithologically complex. For example, strata can vary from a simple coarsening upward shale to a complex series of scour and fill deposits that comprise siltstones and sandstones deposited under moderate- to high-energy flow conditions (trough cross-bedding, internal small-scale scour and fill, plant fossils at angles to and cross-cutting bedding, "rolled" up, and sometimes aligned), to laminated packages of fine sandstone and coarse-to-fine siltstone deposited mainly from suspension in standing bodies of water. The plant fossils described herein were collected from all of these various lithologies. Throughout the study area, the coal identified as the Buffaloville contains a distinctive claystone layer several $\mathrm{cm}$ or more thick. The name Minshall Coal is not used locally, and the transition between the Brazil and Staunton formations is well exposed but complex, paralleling the situation to the north in Greene and Clay counties.

At the time we visited the Nancy Coal Company, Sugar Creek Mine in 1980, no coals were exposed in the area we were permitted to examine, and from which the fossil collection reported herein was made. A limestone bed was present at the top of the exposure but was not positively identified at the time. The base of the section consisted of a $4.6 \mathrm{~m}$ (15 foot) thick rhythmically laminated gray shale with sandy horizons. This unit was erosionally truncated and above it was 0.3-0.6 m (1-2 feet) of burrowed sandy shale of possible marine origin, conformably overlain by $2.1 \mathrm{~m}$ (7 feet) of gray shale that also was erosionally truncated. Above this second erosion surface was 0.3-0.6 $\mathrm{m}$ (1-2 feet) of dirty sandstone, sharply but conformably overlain by $0.9 \mathrm{~m}$ (3 feet) of gray shale below the limestone. Plant fossils were collected from spoils adjacent to this exposure, and fossiliferous slabs are lithologically similar to the dirty sandstone above the uppermost erosion surface. The Nancy Sugar Creek Mine is listed in a contemporary Indiana directory of coal producers as having mined coals in the Staunton Formation. However, the lithologies and plant fossil composition are effectively identical to those found in other collections that make up this study, and especially to those from the NERCO Midway mine, which was located nearby. There also were other mines in the area designated as "Sugar Creek" that extracted Brazil and Staunton formation coals, but so far as our research has revealed, none were operating in 1980. Consequently, although we include this locality in our study, the provenance of the collection must be treated as uncertain.

Several visits were made to the Midway Mine, which was owned by NERCO in 1988 when the plant fossils reported herein were collected. The assemblage comes from between coals identified by us as the Upper Block and Buffaloville. The latter consisted of two benches separated by a thick claystone layer, as is characteristic of the so-called Buffaloville Coal in Daviess County. The section above the Upper Block Coal began with 60 $\mathrm{cm}$ of dark gray, silty shale without plant fossils. This shale was overlain by $30 \mathrm{~cm}$ of siltstone with abundant cordaitalean leaves, the bed from which the plant fossils reported herein were obtained. The top of the cordaitaleanrich siltstone had an erosional contact, above which was $1.2 \mathrm{~m}$ of thinly interbedded siltstone and sandstone with poorly preserved plant-fossil fragments. The top of this unit was pedogenically altered below the Buffaloville Coal, above which a complex Staunton Formation section was present. Exposures in the Midway Mine were examined during two previous visits. In 1980, a section was exposed from the Lower Block Coal to above the Upper Block Coal. The Upper Block Coal was overlain by a coarsening upward unit (0.6-1.0 $\mathrm{m}$ thick) that graded from dark gray clayey shale with plant fossils, mainly lepidodendroid stems and leaves and pteridosperm rachises, to light gray siltstone. This unit was erosionally truncated, and above it was a sandy, dark gray shale with sandstone lenses, dominated by cordaitalean foliage with minor amounts of Sphenopteris sp. (a 1980 field identification, which we might now consider to be Sphenopteridium), neuropteroid fragments, and a calamitalean stem cast. The unit varied in thickness over approximately $200 \mathrm{~m}$ of horizontal exposure. Although no collecting was done in 1980, this probably is the same unit as that collected in 1988. During the second visit in 1982, the Upper Block Coal was at the base of the exposed section, overlain by $3 \mathrm{~m}$ of dark gray clayey shale that coarsened upward slightly; no plant fossils were observed. The Buffaloville Coal rested conformably on this shale and was overlain by a complex section of the Staunton Formation, at the base of which, immediately above the coal, were $10 \mathrm{~cm}$ of pyritic shale that contained marine invertebrate fossils. Above this bed were $4.6 \mathrm{~m}$ of silty shale and $15 \mathrm{~m}$ of stacked paleosols, coals and coaly streaks, and sandstones. Thus, the section between the Upper Block and Buffaloville coals observed 
in 1982 was simpler than that observed in 1980 or 1988 , although the fossiliferous unit detailed herein was not identified at that time.

\subsubsection{Sedimentology}

The plant fossils described in this study were collected without regard to identity or abundance. In addition, the collections were often hastily made due to mining activities or safety considerations in an active mine setting. As a consequence, the collections approximate a random representation of the composition of the fossil population, and the fossiliferous slabs often include large blocks with sedimentological features that reveal depositional conditions. The lithology and sedimentology of the fossilbearing slabs are similar at all collecting localities, so much so that it would be difficult (without provenance data and labels) to differentiate the specimens based on their matrix alone.

The specimens fall into two groups: 1) those deposited in channels characterized by intermittent stream flow, probably with flashy, high discharge volumes; and 2) those deposited in standing bodies of water, either abandoned mainstem fluvial channels or small lakes that resulted from abandonment of floodplain channels. The signatures of both environmental settings may be found in the larger collections.

Many of the fossiliferous slabs show evidence of having been deposited rapidly under intermittent moderateto high-energy flow conditions. Indicators of such conditions include lenses and beds with concentrations of intraformational granules or pebbles of angular to subrounded claystone, siltstone and, less commonly, small transported nodules, possibly sideritic (Fig. 5a). In some collections, these conglomeratic horizons contain plant fossils (Fig. 5b). Plant remains also occur in rocks characterized by small scours or trough cross-bedding. Finally, plant fossils are commonly found at an angle to bedding, either cross-cutting laminae or within massive siltstones (Figs 5c-5d). Some plant remains were rolled up on themselves, as if having been deposited in a sediment-laden slurry, whereas others were angularly disposed and record the rapid deposition of fine-grained sand and silt around them, in graded beds. In contrast to these indicators of rapid burial under moderate- to highenergy flow conditions, other plant fossils, especially larger elements such as axis fragments and cordaitalean or Lesleya leaves, are preferentially oriented on bedding planes, recording lower, but sustained flow (Fig. 5e). In some cases, these large elements were deposited in mats with no preferred orientation, suggesting slow settling from suspension during waning flow. These features, in combination with the range of grain sizes from pebbles to silt in close vertical association, are strongly indicative of flow regimes of variable intensity, with deposition either occurring during pulses of high-energy stream discharge during flash-flood events, or under slack water conditions as flooding waned.

Some fossiliferous slabs are rhythmically laminated, showing alternations between fine-grained sandstone and various grain sizes of siltstone, with laminae varying from $<1 \mathrm{~mm}$ to nearly $5 \mathrm{~mm}$ thick (Fig. 6a). In these deposits, plant fossils are flat lying on bedding planes and generally involve well preserved, large leaves. Such lamination stands in strong contrast to the indicators of variable flow discharge and rapid sediment accumulation found in the majority of the fossiliferous specimens. Nonetheless, the grain sizes in the laminated strata are the same as those seen in the higher energy depositional settings, primarily fine-grained sand. The laminated samples are interpreted to record the periodic introduction of plumes of relatively coarse-grained sediment and plant remains into standing water bodies, after which the sediment and plants settled from suspension. Given the channel-like morphology of the fossiliferous deposits, at least where observable, accumulation probably occurred in relatively small floodplain lakes, possibly created by the abandonment of floodplain channels. There is no evidence that these beds were deposited under tidal influence. The overall sedimentary setting of the various deposits is consistent with deposition on floodplains, perhaps in a larger coastalplain setting, but not within reach of marine or brackish waters.

It also is noteworthy that all fossiliferous units examined contain clasts of fossil charcoal, most of which appears to be charred wood (Fig. 6b). As discussed by Falcon-Lang (1999, 2000), regular fires on the Pennsylvanian landscape reduced the number of rooted plants, causing an increase in sediment stripping and erosion, and hindering rainfall absorption, all of which created conditions suitable for flashy, high flow and sediment discharge into streams.

\subsubsection{Sequence architecture}

Where adequate exposure permitted observation, the fossiliferous deposits described herein were situated between coal beds within small, incised channels, as described above. The deposits appear to have formed prior to or partially contemporaneously with the paleosols that underlie the Minshall-Buffaloville coal bed (Fig. 4; Bashforth et al., 2016b). The paleosols appear similar to many Desmoinesian paleosols higher in the Illinois Basin succession, which are largely polygenetic in origin, evidencing initial formation under seasonally dry conditions, shifting to humid in their later phases, prior to the onset of peat formation across the landscape (Rosenau et al., 2013b). At some locations, the channel-fill deposits containing the fossils were scoured into sediments that 


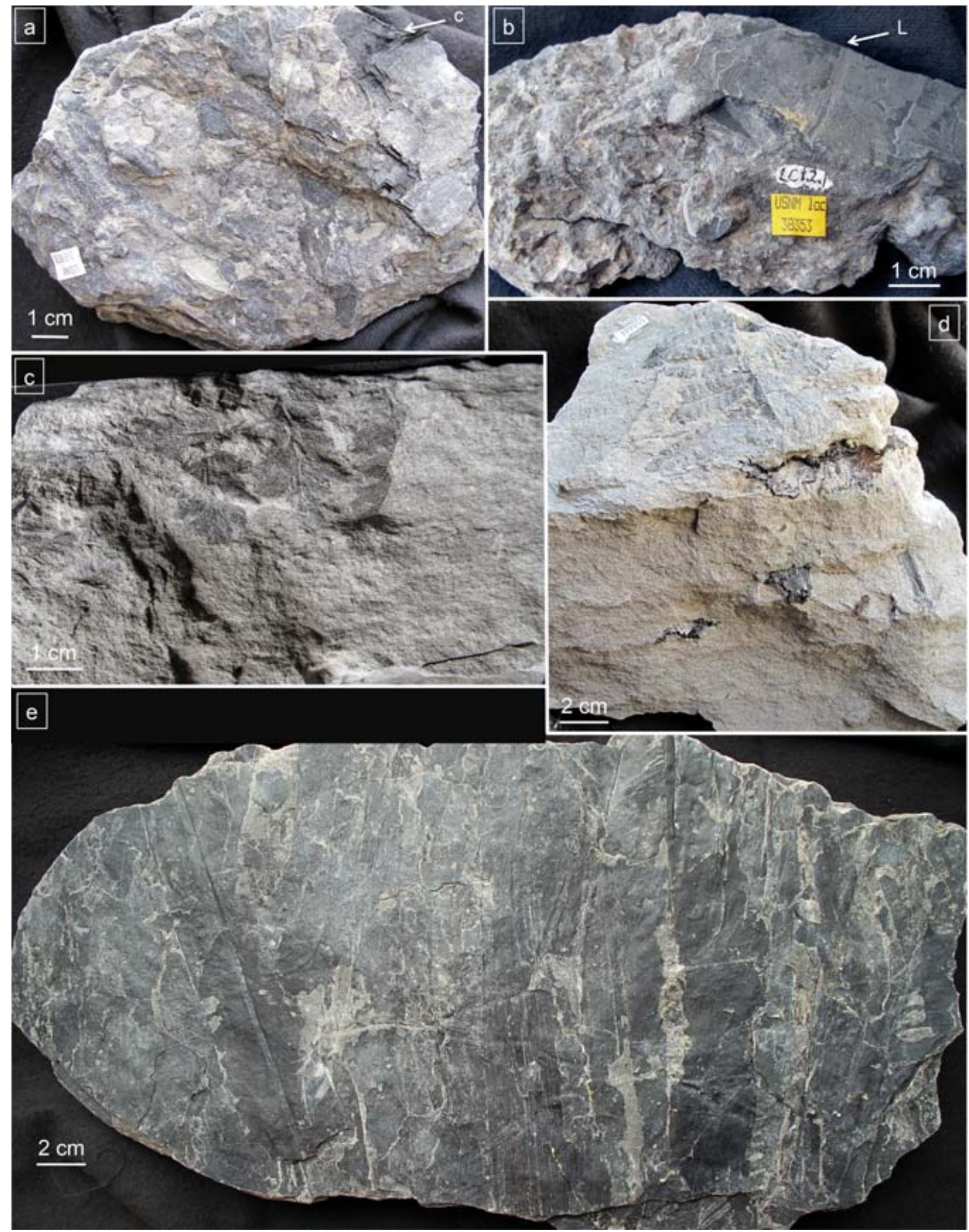

Figure 5. Sedimentology. a) Conglomerate with incorporated plant material, including charcoal (c). b) Conglomerate with a layer of siltstone containing a plant fossil (Lesleya, [L]). USNM specimen 616939. c) Siltstone with Sphenopteridum foliage disposed at right angles to bedding, USNM specimen 616926. d) Angularly bedded siltstone with plant material on and at angles to bedding, including lobatopteroid fern foliage on upper surface, USNM specimen 558444. e) Foliage in parallel alignment, including Lesleya, Taeniopteris and Cordaites, USNM specimen 558427. 

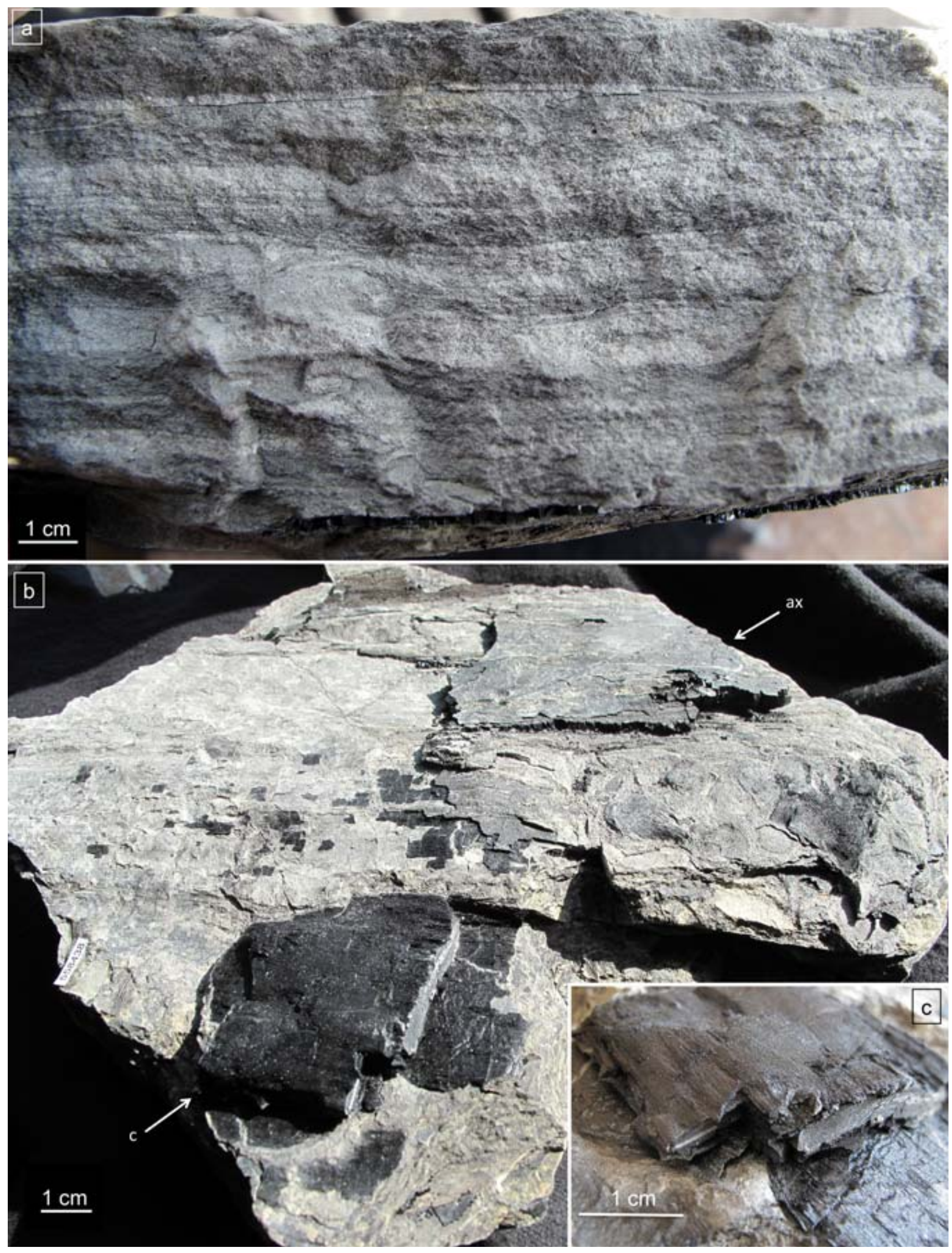

Figure 6. Sedimentology. a) Rhythmically laminated siltstone and fine-grained sandstone, note micro-scours, USNM specimen 558449. b) Conglomerate with large charcoal clast (c) and large coalified axis (ax), probably the remains of a woody stem, USNM specimen 558438. c) Closeup of charcoal clast, USNM specimen 558438. 
contained evidence of brackish to marine invertebrate fossils.

The consistent stratigraphic positions of the fossiliferous beds, below coals in channels formed laterally to paleosols, and the nature of the sediments enclosing the plant remains, suggestive of flashy discharge stream deposits, suggests that these deposits most likely formed on the exposed cratonic surface during sea-level fall or early lowstand, thus initially on a coastal plain, as the sea withdrew and exposed the craton, but increasingly, through time, at interior locations (Bashforth et al., 2016b). As described by a number of different investigations that focused on climate-sediment relations with respect to glacioeustatic cycles (Cecil et al., 2003; Eros et al., 2012; Horton et al., 2012; Rosenau et al., 2013a, b), glacioeustatic lowstand probably began under seasonally dry conditions and became more intensely wet during middle to late lowstand, at glacial maximum.

\section{MACROFLORA}

\subsection{Macroflora identification and quantification}

During the identification process, we endeavored to differentiate fossil-taxa described from North America from similar, albeit subtly different, taxa described from Europe, in a cautious effort not to make unwarranted biogeographic extensions. In reality, the floral diversity was so low, and the remains of pteridosperms and ferns so fragmentary, that many identifications are only tentative. The descriptions provided are intended to substantiate our identifications. No synonymy lists are given.

Where necessary, and if possible, fossils were prepared using an air scribe or needles to remove rock matrix. If loose cuticle was present, preparation was done without blowing forced air over the specimen. All photography was done with natural window or outdoor lighting.

All samples were quantified using a consistent method, a variant of the quadrat technique of Pfefferkorn et al. (1975). In this approach, every hand sample is treated as a pair of sampling "quadrats", with the upper and lower surfaces quantified separately; counterparts are excluded. All taxa observable on a given quadrat surface, identified to the lowest possible taxonomic rank, are counted as being present once, regardless of the number of specimens on the surface. This approach accounts for differences in the size of elements produced by various Pennsylvanian-age taxa (e.g., does a large lycopsid stem 'count' as much as a small marattialean tree-fern pinnule?); such size differences are a less significant problem when quantifying quadrat occurrences. Barren surfaces are noted but not used to compile the total number of quadrats examined, nor are they used to compute percentage occurrences. The end result of this census analysis is a frequency distribution - i.e., the proportion of the total quadrat sample that contains any particular taxon. Hypothetically, all taxa could be present on all quadrats. In fact, comparisons of count methods and quadrat methods (e.g., Lamboy \& Lesnikowska, 1988; DiMichele et al., 1991) show that both produce similar rank-order results. However, count data may misconstrue original biomass if the elements being counted are not approximately the same size and construction. In contrast, frequency data tend to underestimate dominance and inflate rarity by downplaying fragment-size differences and undercounting occurrences where remains are clustered (Wing \& DiMichele, 1995).

\subsection{Macrofloral taxonomic composition}

The flora described herein consists of 15 taxa (not including reproductive organs) combined from the six localities examined (Tables 1,2). This number is reduced to a minimum of 14 by elimination of calamitalean stems, appropriate given that two kinds of calamitalean foliage are present. However, the number was probably greater given the likelihood of several species of cordaitalean foliage and possibly two species of sphenopterid filicalean fern foliage, which might push the number closer to 20 . In no instance do reproductive organs occur at a locality without a suspected parent plant (foliage type) also being present. Eight of the 15 taxa occur at only one locality, and so might be characterized as being rare in spatial context, and four taxa only occur at two localities. Additionally, three of the eight spatially rare taxa occur as singletons, and thus also are numerically rare.

The most abundant elements in the flora qualify as "dryland" plants (Fig. 7), typical of environments in which seasonal drought is often inferred from various lines of evidence (e.g., Bashforth et al., 2014, 2016b). Such plants also may have occupied those parts of the landscape characterized by water-table fluctuations, leading to seasonal moisture deficits. Such "dryland" plants include several kinds of Cordaites, Lesleya sp., Taeniopteris sp. cf. T. multinervia and Sphenopteridium sp. (cf. Sphenopteris germanica). Two types of enigmatic, probable seed plants also occur as singletons, their morphologies suggestive of dryland affinities.

The remainder of the flora consists of taxa that generally are considered characteristic of humid climates, or of substrates with high water tables and thus minimal periods of water deficit (Fig. 7). These "wetland" plants include pteridosperms (Linopteris neuropteroides, Karinopteris/ Eusphenopteris sp.); ferns of possible marattialean affinity (but see discussion below); filicalean ferns (Sphenopteris [one or more species] and possibly Zeilleria avoldensis); 
Table 1. Quantitative macrofloral composition of six Indiana dryland floras. Shown are (1) number of quadrats analyzed from each locality, (2) number of quadrats on which each taxon was identified and the percentage of quadrats that occurrence represents, (3) summaries of the total number of quadrats, percentage occurrence on all quadrats from the six localities, the mean occurrence frequency among the six localities, and the number of localities at which the taxon was identified.

\begin{tabular}{|c|}
\hline $\begin{array}{r}\text { Log Cabin Ashboro/46 } \\
\text { USNM } 38353\end{array}$ \\
\hline $\begin{array}{l}\text { USNM } 38353 \\
\text { Brazil Coal \& Clay Saline No.1 }\end{array}$ \\
\hline USNM 38878 \\
\hline Northern Coal New Britton \\
\hline USNM 43877 \\
\hline Comet Coal \& Clay Duke's \\
\hline USNM 38326 \\
\hline Nancy Coal Sugar Creek \\
\hline USNM 38360 \\
\hline NERCO Midway \\
\hline USNM 38898 \\
\hline TOTAL QUADRATS \\
\hline Mean $\%$, combined quadrats \\
\hline Mean, site \% \\
\hline Number of site occurrences \\
\hline
\end{tabular}

Quadrats Barren Qs Cordaites

$\begin{array}{cccc} & & & \text { phylloides } \\ \text { Log Cabin Ashboro/46 } & 1 & 0 & 1 \\ \text { USNM 38353 } & 0.014 & 0.000 & 0.014 \\ \text { Brazil Coal \& Clay Saline No.1 } & 0 & 0 & 0 \\ \text { USNM 38878 } & 0.000 & 0.000 & 0.000 \\ \text { Northern Coal New Britton } & 1 & 0 & 0 \\ \text { USNM 43877 } & 0.015 & 0.000 & 0.000 \\ \text { Comet Coal \& Clay Duke's } & 0 & 0 & 0 \\ \text { USNM 38326 } & 0.000 & 0.000 & 0.000 \\ \text { Nancy Coal Sugar Creek } & 3 & 3 & 0 \\ \text { USNM 38360 } & 0.036 & 0.036 & 0.000 \\ \text { NERCO Midway } & 0 & 0 & 0 \\ \text { USNM 38898 } & 0.000 & 0.000 & 0.000 \\ \text { TOTAL QUADRATS } & 5 & 3 & 1 \\ \text { Mean \%, combined quadrats } & 0.017 & 0.010 & 0.003 \\ \text { Mean, site \% } & 0.011 & 0.006 & 0.002 \\ \text { Number of site occurrences } & 3 & 1 & 1\end{array}$

\begin{tabular}{|c|c|c|}
\hline Lesleya & Taeniopteris & $\begin{array}{l}\text { Sphenop- } \\
\text { teridium }\end{array}$ \\
\hline 35 & 16 & 0 \\
\hline 0.486 & 0.222 & 0.000 \\
\hline 41 & 0 & 0 \\
\hline 0.732 & 0.000 & 0.000 \\
\hline 0 & 0 & 10 \\
\hline 0.000 & 0.000 & 0.154 \\
\hline 5 & 0 & 1 \\
\hline 0.500 & 0.000 & 0.100 \\
\hline 22 & 3 & 0 \\
\hline 0.265 & 0.036 & 0.000 \\
\hline 0 & 0 & 0 \\
\hline 0.000 & 0.000 & 0.000 \\
\hline 103 & 19 & 11 \\
\hline 0.343 & 0.063 & 0.037 \\
\hline 0.331 & 0.043 & 0.042 \\
\hline 4 & 2 & 2 \\
\hline $\begin{array}{l}\text { Calamo- } \\
\text { stachys }\end{array}$ & $\begin{array}{c}\text { Incertae } \\
\text { Sedis A }\end{array}$ & $\begin{array}{l}\text { Incertae } \\
\text { Sedis B }\end{array}$ \\
\hline 1 & 2 & 0 \\
\hline 0.014 & 0.028 & 0.000 \\
\hline 0 & 0 & 0 \\
\hline 0.000 & 0.000 & 0.000 \\
\hline 0 & 0 & 0 \\
\hline 0.000 & 0.000 & 0.000 \\
\hline 0 & 0 & 0 \\
\hline 0.000 & 0.000 & 0.000 \\
\hline 0 & 0 & 2 \\
\hline 0.000 & 0.000 & 0.024 \\
\hline 0 & 0 & 0 \\
\hline 0.000 & 0.000 & 0.000 \\
\hline 1 & 1 & 2 \\
\hline 0.003 & 0.003 & 0.007 \\
\hline 0.002 & 0.005 & 0.004 \\
\hline 1 & 1 & 1 \\
\hline
\end{tabular}

\begin{tabular}{|c|c|c|}
\hline $\begin{array}{l}\text { Lobatop- } \\
\text { teroid }\end{array}$ & Pecopteris & $\begin{array}{c}\text { Linopteris } \\
\text { neurop- } \\
\text { teroides }\end{array}$ \\
\hline 1 & 3 & 0 \\
\hline 0.014 & 0.042 & 0.000 \\
\hline 0 & 0 & 1 \\
\hline 0.000 & 0.000 & 0.018 \\
\hline 5 & 0 & 0 \\
\hline 0.077 & 0.000 & 0.000 \\
\hline 0 & 0 & 2 \\
\hline 0.000 & 0.000 & 0.200 \\
\hline 0 & 0 & 0 \\
\hline 0.000 & 0.000 & 0.000 \\
\hline 0 & 0 & 0 \\
\hline 0.000 & 0.000 & 0.000 \\
\hline 6 & 3 & 3 \\
\hline 0.020 & 0.010 & 0.010 \\
\hline 0.015 & 0.007 & 0.036 \\
\hline 2 & 1 & 2 \\
\hline Samaropsis & $\begin{array}{l}\text { Unwinged } \\
\text { seed }\end{array}$ & $\begin{array}{c}\text { Large } \\
\text { Platypsper- } \\
\text { mic Seed }\end{array}$ \\
\hline 1 & 0 & 0 \\
\hline 0.014 & 0.000 & 0.000 \\
\hline 1 & 10 & 1 \\
\hline 0.018 & 0.179 & 0.018 \\
\hline 7 & 0 & 0 \\
\hline 0.108 & 0.000 & 0.000 \\
\hline 0 & 0 & 0 \\
\hline 0.000 & 0.000 & 0.000 \\
\hline 1 & 0 & 0 \\
\hline 0.012 & 0.000 & 0.000 \\
\hline 1 & 0 & 0 \\
\hline 0.071 & 0.000 & 0.000 \\
\hline 11 & 10 & 1 \\
\hline 0.037 & 0.033 & 0.003 \\
\hline 0.037 & 0.030 & 0.003 \\
\hline 5 & 1 & 1 \\
\hline
\end{tabular}

\begin{tabular}{|c|c|c|}
\hline Karinopteris & $\begin{array}{l}\text { Sphenop- } \\
\text { teris }\end{array}$ & $\begin{array}{l}\text { Senftenbergi } \\
\text { plumosa }\end{array}$ \\
\hline 0 & 0 & 0 \\
\hline 0.000 & 0.000 & 0.000 \\
\hline 0 & 0 & 0 \\
\hline 0.000 & 0.000 & 0.000 \\
\hline 0 & 2 & 0 \\
\hline 0.000 & 0.031 & 0.000 \\
\hline 0 & 0 & 0 \\
\hline 0.000 & 0.000 & 0.000 \\
\hline 0 & 0 & 8 \\
\hline 0.000 & 0.000 & 0.096 \\
\hline 1 & 0 & 0 \\
\hline 0.071 & 0.000 & 0.000 \\
\hline 1 & 2 & 8 \\
\hline 0.003 & 0.007 & 0.027 \\
\hline 0.012 & 0.005 & 0.016 \\
\hline 1 & 1 & 1 \\
\hline Axes & Roots & Charcoal \\
\hline 61 & 0 & 19 \\
\hline 0.847 & 0.000 & 0.264 \\
\hline 26 & 0 & 19 \\
\hline 0.464 & 0.000 & 0.339 \\
\hline 15 & 2 & 2 \\
\hline 0.231 & 0.031 & 0.031 \\
\hline 0 & 0 & 2 \\
\hline 0.000 & 0.000 & 0.200 \\
\hline 9 & 0 & 2 \\
\hline 0.108 & 0.000 & 0.024 \\
\hline 3 & 0 & 2 \\
\hline 0.214 & 0.000 & 0.143 \\
\hline 114 & 2 & 46 \\
\hline 0.380 & 0.007 & 0.153 \\
\hline 0.311 & 0.005 & 0.167 \\
\hline 4 & 1 & 5 \\
\hline
\end{tabular}

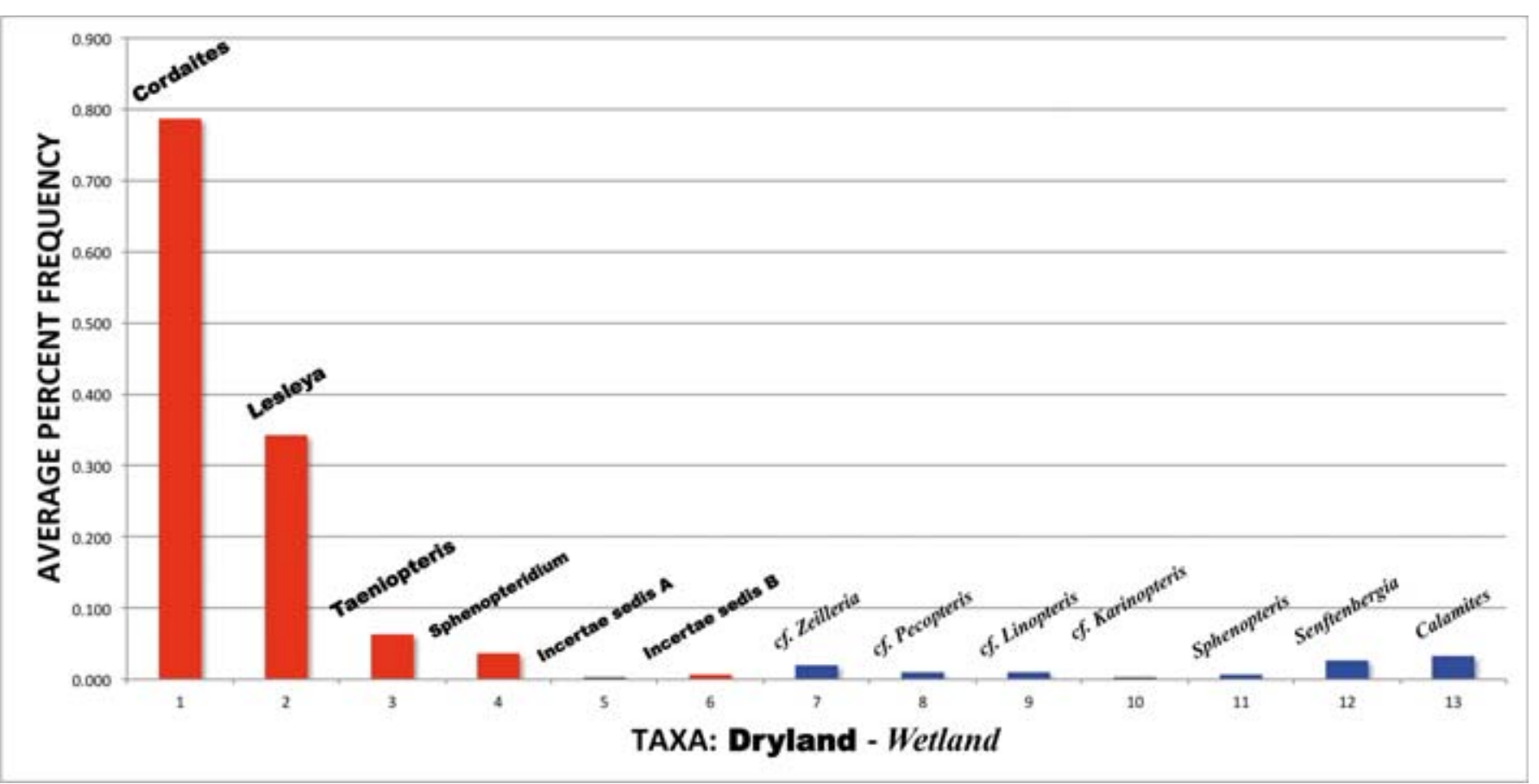

Figure 7. Average percent frequency of quadrat-occurrence of major taxa in the six sampled dryland locations. Dryland elements in red and bold font. Wetland elements in blue and italic font. 
Table 2. Four rank-order assessments of macrofloral dominance. (1) Number of locality (site) occurrences. (2) Mean percent frequency of locality (site) abundances. (3) Percent frequency in the entire 300-quadrat sample. (4) Summary rank order based on the three other means of assessment. $*=$ dryland taxa.

\begin{tabular}{|c|c|c|c|c|}
\hline Site Number & \# Sites & \# Quad's & \multicolumn{2}{|c|}{ \% All Quad's Mean Site \% } \\
\hline Cordaites & 6 & 236 & 78.6 & 81.9 \\
\hline Lesleya & 4 & 103 & 34.3 & 33.1 \\
\hline Calamites & 3 & 5 & 1.7 & 1.1 \\
\hline Taeniopteris & 2 & 19 & 6.3 & 4.3 \\
\hline Sphenopteridium & 2 & 11 & 3.7 & 4.2 \\
\hline Lobatopteroid & 2 & 6 & 2.0 & 1.5 \\
\hline Linopteris & 2 & 3 & 1.0 & 3.6 \\
\hline Senftenbergia & 1 & 8 & 2.7 & 1.6 \\
\hline Annularia sp & 1 & 3 & 1.0 & 0.6 \\
\hline Pecopteris & 1 & 3 & 1.0 & 0.6 \\
\hline Sphenopteris & 1 & 2 & 0.7 & 0.5 \\
\hline Incertae Sedis B & 1 & 2 & 0.7 & 0.5 \\
\hline Incertae Sedis A & 1 & 1 & 0.7 & 0.4 \\
\hline Karinopteris & 1 & 1 & 0.3 & 1.2 \\
\hline Annularia spheno & 1 & 1 & 0.3 & 0.2 \\
\hline$\%$ All Quadrats & \# Sites & \# Quad's & \multicolumn{2}{|c|}{ \% All Quad's Mean Site \% } \\
\hline Cordaites & 6 & 236 & 78.6 & 81.9 \\
\hline Lesleya & 4 & 103 & 34.3 & 33.1 \\
\hline Taeniopteris & 2 & 19 & 6.3 & 4.3 \\
\hline Sphenopteridium & 2 & 11 & 3.7 & 4.2 \\
\hline Senftenbergia & 1 & 8 & 2.7 & 1.6 \\
\hline Lobatopteroid & 2 & 6 & 2.0 & 1.5 \\
\hline Calamites & 3 & 5 & 1.7 & 1.1 \\
\hline Linopteris & 2 & 3 & 1.0 & 3.6 \\
\hline Annularia sp & 1 & 3 & 1.0 & 0.6 \\
\hline Pecopteris & 1 & 3 & 1.0 & 0.6 \\
\hline Sphenopteris & 1 & 2 & 0.7 & 0.5 \\
\hline Incertae Sedis B & 1 & 2 & 0.7 & 0.5 \\
\hline Incertae Sedis A & 1 & 1 & 0.7 & 0.4 \\
\hline Karinopteris & 1 & 1 & 0.3 & 1.2 \\
\hline Annularia spheno & 1 & 1 & 0.3 & 0.2 \\
\hline
\end{tabular}

Mean Site \%
Cordaites
Lesleya
Taeniopteris
Sphenopteridium
Linopteris
Senftenbergia
Lobatopteroid
Karinopteris
Calamites
Annularia sp
Pecopteris
Sphenopteris
Incertae Sedis B
Incertae Sedis A
Annularia spheno

\section{Summary}

Cordaites*

Lesleya*

Taeniopteris*

Sphenopteridium*

Senftenbergia

Lobatopteroid

Calamites

Linopteris*

Annularia sp

Pecopteris

Sphenopteris

Karinopteris

Unknown B*

Unknown A*

Annularia spheno

$\begin{array}{cccc}\text { \# Sites } & \text { \# Quad's } & \text { \% All Quad's } & \text { Mean Site \% } \\ 6 & 236 & 78.6 & 81.9 \\ 4 & 103 & 34.3 & 33.1 \\ 2 & 19 & 6.3 & 4.3 \\ 2 & 11 & 3.7 & 4.2 \\ 2 & 3 & 1.0 & 3.6 \\ 1 & 8 & 2.7 & 1.6 \\ 2 & 6 & 2.0 & 1.5 \\ 1 & 1 & 0.3 & 1.2 \\ 3 & 5 & 1.7 & 1.1 \\ 1 & 3 & 1.0 & 0.6 \\ 1 & 3 & 1.0 & 0.6 \\ 1 & 2 & 0.7 & 0.5 \\ 1 & 2 & 0.7 & 0.5 \\ 1 & 1 & 0.7 & 0.4 \\ 1 & 1 & 0.3 & 0.2\end{array}$

$\begin{array}{ccc}\text { Ranks } & \text { Mean Rank } & \text { Sum Rank } \\ 1,1,1 & 1.0 & 1 \\ 2,2,2 & 2.0 & 2 \\ 4,3,3 & 3.3 & 3 \\ 5,4,4 & 4.3 & 4 \\ 8,6,5 & 6.3 & 5 \\ 6,7,6 & 6.3 & 5 \\ 3,9,7 & 6.3 & 5 \\ 6,7,8 & 7.0 & 8 \\ 9,10,9 & 9.3 & 9 \\ 10,11,10 & 10.3 & 10 \\ 11,12,11 & 11.3 & 11 \\ 14,8,14 & 12.0 & 12 \\ 12,13,12 & 12.3 & 13 \\ 13,14,13 & 13.3 & 14 \\ 15,15,15 & 15.0 & 15\end{array}$

a zygopteridalean fern (Senftenbergia plumosa) and calamitalean sphenopsids (Annularia sphenophylloides, Annularia sp.). Among this group, therefore, are plants that most likely had low-growing or sprawling (Sphenopteris, Senftenbergia, Zeilleria) growth habits, plant types that can be difficult to detect in certain types of environments and under taphonomic conditions unfavorable for the sampling and preservation of groundcover (Scheihing, 1980).

\subsubsection{Cordaitalean foliage \& platyspermic seeds}

Cordaitalean foliage (i.e., Cordaites Unger), which dominates or co-dominates all studied assemblages, has not been segregated into different species, which requires the examination of cuticles. However, the macromorphology of the leaves, including variations in leaf widths and the prominence and width of veins, suggests that several species are included in the Cordaites spp. category (Fig. 8). Despite the abundance of cordaitalean foliage, leaf tips and bases (Figs $8 \mathrm{f}-8 \mathrm{~g}$ ) are rare in the collections, most likely reflecting the considerable length of the original leaves and thus the greater likelihood of sampling the main leaf blade rather than either end.

Studies by Z. Šimůnek and colleagues (e.g., Šimůnek, 2000, 2007, 2008; Šimůnek \& Libertín, 2006; Šimůnek et al., 2009) have demonstrated that cordaitalean leaves that appear morphologically identical in hand sample or under low magnification may, in fact, be differentiable based on cuticular features. These findings imply that Pennsylvanian cordaitaleans had a much higher diversity than can be appreciated based on the examination of adpressions alone. However, natural biological species have yet to be fully recognized because the range of variability remains unknown. Nonetheless, the study of cuticles has permitted the segregation of foliage into a range of types that may eventually form the basis on which biologically meaningful species can be discerned (e.g., Šimůnek \& Florjan, 2013), work substantiated by chemotaxonomic analysis (Zodrow et al., 2000, 2003).

The realization that cordaitalean biodiversity is substantially higher than previously appreciated is complemented by studies of cordaitalean remains in coal- 


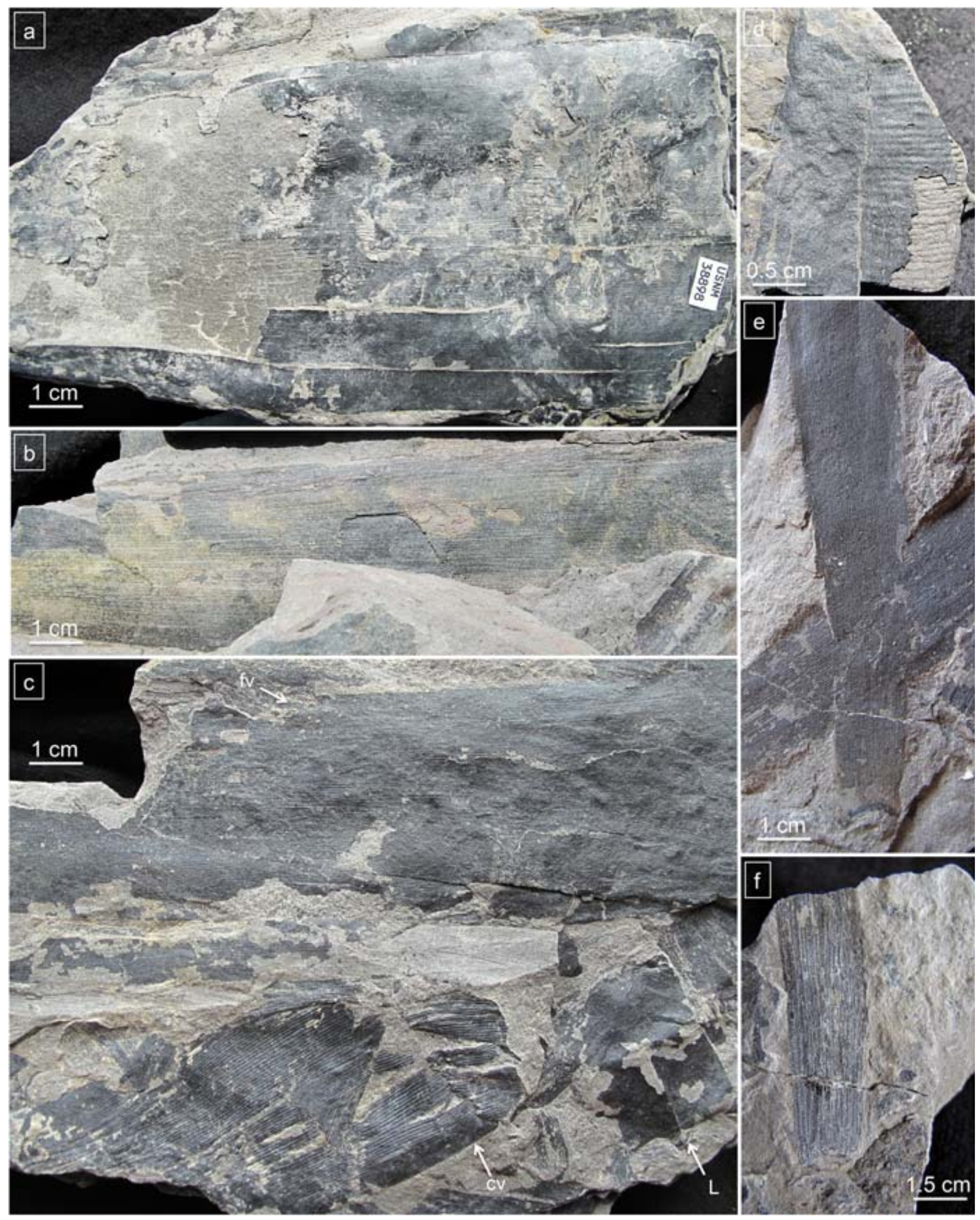

Figure 8. Cordaitalean remains. a) Wide Cordaites leaf, USNM specimen 558420. b) Cordaites leaf of medium width, showing the beginnings of basal taper (left side), USNM specimen 558428. c) Cordaites leaves with fine venation (fv) and coarse, prominent venation (cv); fragment of Lesleya leaf (L), USNM specimen 558437. d) Artisia, cordaitalean stem pith cast, USNM specimen 616938. e) Base of fine-veined Cordaites leaf showing taper and lunate attachment area with thickened rim, USNM specimen 558446. f) Base of coarse-veined Cordaites leaf showing lunate attachment area. USNM specimen 616935. 
swamp settings, preserved in coal balls (e.g., Rothwell \& Warner, 1984; Costanza, 1985; Trivett \& Rothwell, 1985 ), from which a variety of cordaitalean taxa and growth habits have been documented. In addition, this group was quantitatively abundant in coal-swamp environments (e.g., Phillips et al., 1985; Raymond, 1988; Raymond et al., 2010), particularly in the lower $2 / 3$ of the Middle Pennsylvanian. In fact, the "last gasp" of notable cordaitalean abundance is in the early Desmoinesian, just above the interval from which the collections described herein were drawn.

Perplexingly, the blanket characterization of this group as "upland" plants persists in the literature, largely based on studies of palynology and adpressed macrofossil remains. Yet cordaitalean abundance in coal swamp habitats was well documented (e.g., Darrah, 1939; Harms \& Leisman, 1961; Cridland, 1964) long before the aforementioned, more recent studies. Far from being limited to upland habitats, the cordaitaleans were a group of great taxonomic and ecological diversity. Viewed from a northern hemisphere temperate-climate bias (see
Pfefferkorn, 1995), the cordaitaleans might be described as "the oaks of the Paleozoic". As a group they appear to have grown from marginal marine swamps to well drained, true upland settings and everywhere in between, and to have encompassed growth habits from giant trees to shrubs and small scrambling forms.

Platyspermic winged seeds, typical of those generally assigned to the cordaitaleans, were, like all reproductive remains, rare in the collections. Small platyspermic seeds, < $1 \mathrm{~cm}$ in diameter, were identified on nine quadrats from three localities (Figs 9a-9d). One large platyspermic seed, $>1 \mathrm{~cm}$ diameter and lacking a clearly developed wing (Fig. 9e), perhaps also of cordaitalean origin, was observed.

\subsubsection{Lesleya $s p$. \& associated seeds}

Foliage identified as Lesleya Lesquereux occurs at four of six localities, at occurrence frequencies between approximately $25 \%$ and $75 \%$ of sample quadrats. Most foliage is fragmentary or partially obscured by burial under similar leaves or Cordaites.

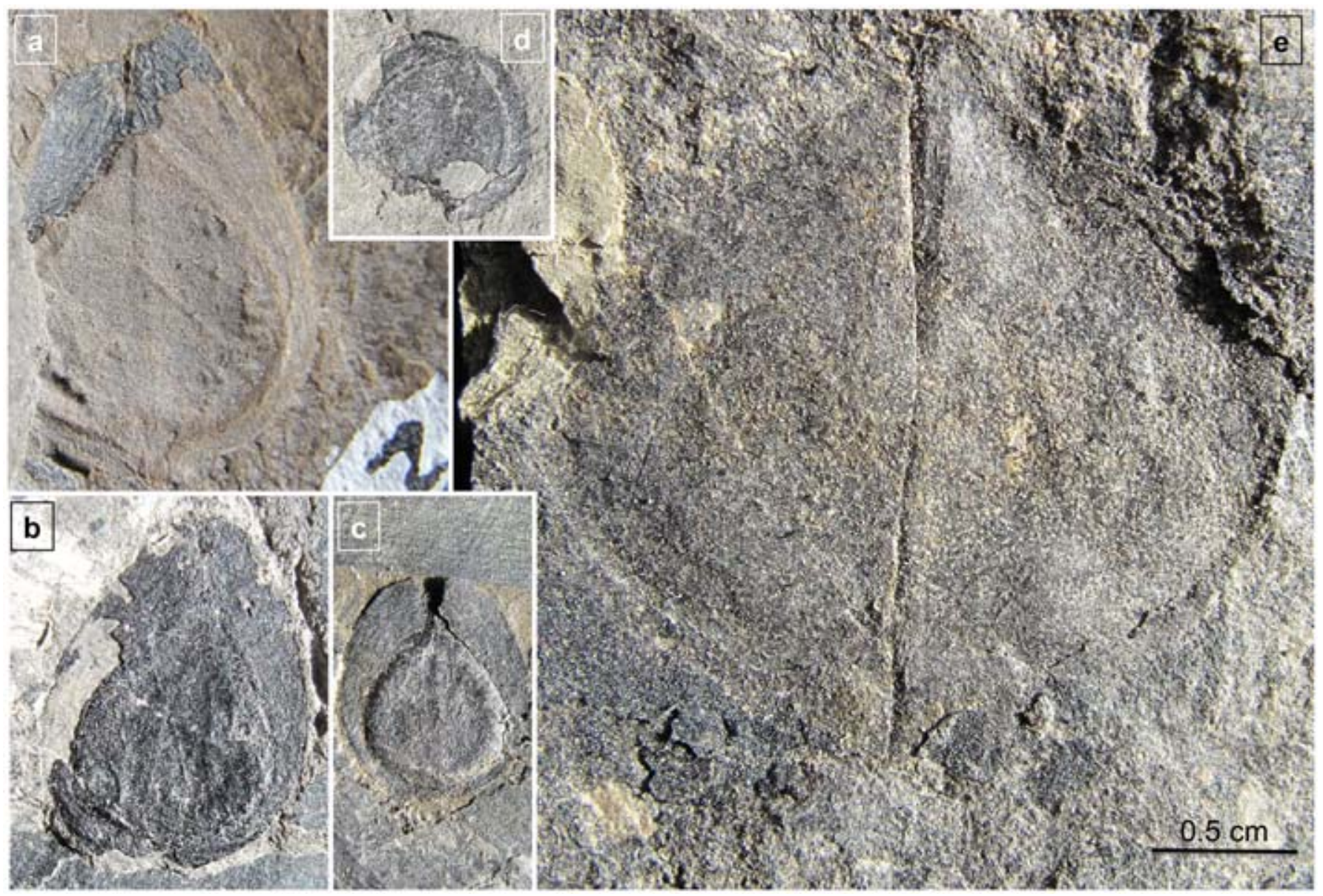

Figure 9. Platyspermic ovules/seeds, all shown at the same magnification (scale bar in image e). a) USNM specimen 558426. b) USNM specimen 616937. c) USNM specimen 558419. d) USNM specimen 558449. e) USNM specimen 558440. 
Identification mainly is based on the large, strap-like aspect of the leaves, which are 4-5 $\mathrm{cm}$ wide, can exceed $25 \mathrm{~cm}$ in length (without tip or base), and have sub-parallel lateral margins (Fig. 10a). The well-demarcated midvein is up to $4 \mathrm{~mm}$ wide in the main part of the lamina. The lateral venation is distinctive, being open-dichotomous and non-reticulate. Secondary veins are dense, follow a 'Z-' or 'epsilon-shaped' path across the lamina, and fork several times, particularly close to the midvein. Rare leaf bases exhibit a gradual, asymmetrical tapering of the lamina proximally (Fig. 10b). Rare leaf tips, of suspected Lesleya affinity, gradually taper over a distance of more than 2-4 cm to apices that vary from blunt and almost rounded (e.g., Bashforth et al., 2016b, figs 6.3, 7) to bluntly pointed (Fig. 10c). Lateral veins in terminal portions of the leaf are relatively steeply ascending and straight, whereas the midvein thins to $<1 \mathrm{~mm}$ wide, ending near the leaf terminus.

Specimens of Lesleya found in the studied floras cannot be assigned with certainty to either Lesleya grandis Lesquereux or Lesleya cheimarosa Leary \& Pfefferkorn, the species with which they are most similar. The overall dimensions, generally straight to sub-parallel lateral margins, venation density and branching pattern, and somewhat pointed apices are most similar to $L$. cheimarosa. Bashforth et al. (2016b) suggested keeping the specimens in open nomenclature until cuticular studies are carried out.
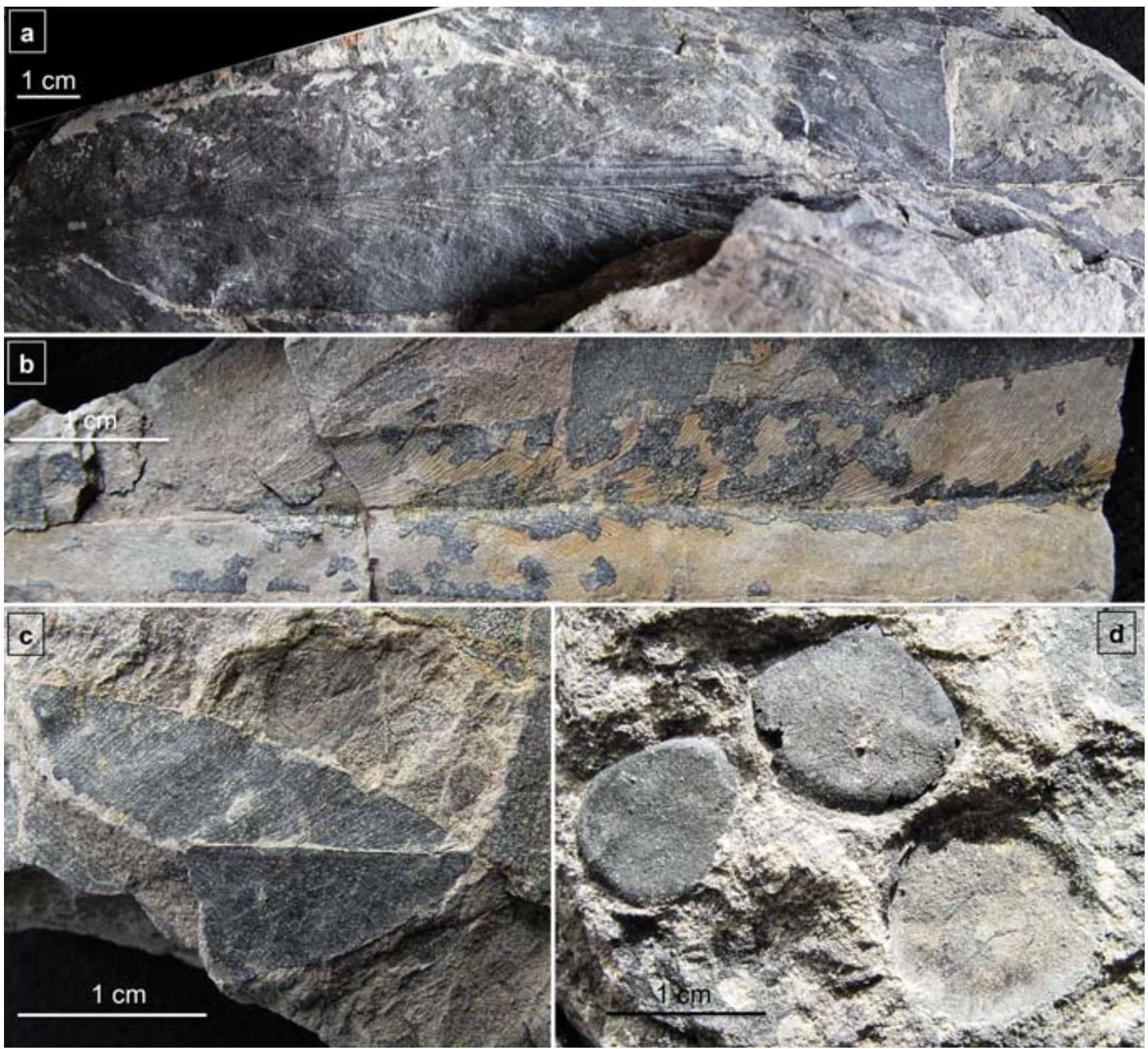

Figure 10. Lesleya sp. and its probable seeds. a) Main portion of lamina showing wide midvein and steep, arching secondary veins, USNM specimen 558439. b) Narrow, tapering lamina from near leaf base, USNM specimen 558424. c) Leaf tip, USNM specimen 558425. d) Three seeds, USNM specimen 558441. 
The affinities of Lesleya are uncertain. The genus is generally considered a seed plant (Florin, 1934; Němejc, 1968), and relationships with both Glossopteris Brongniart (Leary, 1998) and primitive cycads (Remy \& Remy, 1978; Leary, 1990) have been suggested. Distinctive round seeds (Fig. 10d) without a wing or notable surface ornamentation, and having a thick, vitrinitic character, are common at the Brazil Coal and Clay, Saline Pit No. 1 locality (18\% of 56 quadrats, often with more than one seed per quadrat). Lesleya leaves are the most frequently encountered plant (73 \% of quadrats) in this moderately sized collection. The association of vegetative and reproductive organs is weak evidence of disaggregation from a common parent plant, but the correlation is noteworthy.

In fragmentary preservation, Lesleya easily can be confused with Taeniopteris (Bashforth et al., 2016b), which also is present in assemblages studied herein (see below). Likewise, primitive forms of Glossopteris or Megalopteris Dawson ex Andrews, which were not identified in our collections, can bear a strong resemblance to Lesleya.

\subsubsection{Taeniopteris $s p$. $c f$. T. multinervia}

Foliage with the morphology of Taeniopteris was identified at two of six localities: Log Cabin Ashboro/46 Pit, in Clay County (Bashforth et al., 2016b) and Nancy Coal Sugar Creek Mine, in Daviess County, at opposite ends of the study area. Specimens at the Clay County location have an occurrence frequency of approximately $22 \%$, whereas those in Daviess County are at $4 \%$.

The specimens are most similar to Taeniopteris multinervia Weiss. They may exceed $17 \mathrm{~cm}$ in length, based on the largest fragment, with widths over $5 \mathrm{~cm}$. The lateral margins are primarily parallel, but taper toward the base and apex. Midveins are wide, exceeding $3 \mathrm{~mm}$, and taper distally (Fig. 11). The open-dichotomous lateral venation departs the midvein at a steep angle, arches relatively slowly, and reaches a horizontal disposition approximately $1 / 3$ of the way to the lateral margin (Fig. 11b). The distance between lateral veins is greater near the midvein, in the initial, steepest part of the vein trajectory, where dichotomies also are most common. The lateral venation is dense, between $28-45$ veins per $\mathrm{cm}$ on the lateral margin. The leaves appear to have been coriaceous and probably stiff, based on their size, the stout midvein, and the lack of evidence of tearing on most specimens.

Attribution of these specimens to Taeniopteris is uncontroversial based on their morphology. However, as Bashforth et al. (2016b) noted, a late Atokan (early Asturian) occurrence of this genus may be the earliest yet recorded with some confidence. Wagner (in van Loon, 1971) referred a specimen from the Bolsovian of Spain to Taeniopteris? sp., however attribution to Lesleya also must be considered a possibility, based on the high- angle disposition of the secondary veins. Assignment of the Illinois Basin specimens to T. multinervia is less confident, as the range of this species is, to date, confined to Upper Pennsylvanian and lower Permian strata (Remy \& Remy, 1975). Considering the few diagnostic features of Taeniopteris, it is possible that these Middle Pennsylvanian occurrences represent a distinct species. Distinguishing the specimens from Lesleya is an equally vexing matter. Variation in the morphological features of both genera permits the possibility that what we have assigned to Taeniopteris sp. cf. T. multinervia actually is an end-member state in the range of variation of Lesleya sp., which is more common and frequently co-occurs with Taeniopteris foliage. This perplexing possibility was considered in detail by Bashforth et al. (2016b), who chose to separate the two taxa based on morphological differences.

\subsubsection{Sphenopteridium $s p$. or Sphenopteris germanica}

Foliage similar to Sphenopteridium Schimper, cf. $S$. manzanitanum Mamay, and Sphenopteris germanica Weiss, which may be congeneric, occurs in $15 \%$ of quadrats at the Northern Coal, New Britton Pit locality, and as a single fragment at the Comet Coal and Clay locality. Differentiating the vegetative foliage of these two taxa is problematic because of the general similarities in form. More diagnostic reproductive evidence is restricted to palynology, and then only to what does not occur, rather than to a positive occurrence.

Specimens in the collections mainly consist of fragments of penultimate and ultimate pinnae (Figs 12a-12f). Transitions exist among the laminar surfaces, making it difficult to identify or differentiate a large pinnule from an ultimate pinna with multiple pinnules. The maximum rachis diameter is approximately $1.25 \mathrm{~mm}$; the penultimate rachis can be slightly flexuous, deflecting where an ultimate pinna is inserted. Faint transverse bars may occur on the rachises, created by internal cortical sclerenchyma plates, although due to the coarse-grained matrix, such bars can be difficult to differentiate from irregularities on the compression surface where sandstone grains are impressed onto the fossil. Depending on how one delimits a pinnule, laminate surfaces vary from one- to four-lobed (Fig. 12e). If multi-lobed, the lobes are separated by deep sinuses, with some further subdivided into two or three additional lobes by shallow sinuses (Figs 12d, 12f). Pinnules (or pinnule lobes) generally are straight-sided and arise obliquely from the ultimate rachis at $45^{\circ}$ or more. Pinnule apices vary from rounded to nearly square, and some have margins with very small, rounded teeth, in which the veins terminate (Figs 12d, 12f, at arrows). Pinnules are constricted at the base, but attachment to the ultimate pinna rachis is broad enough 


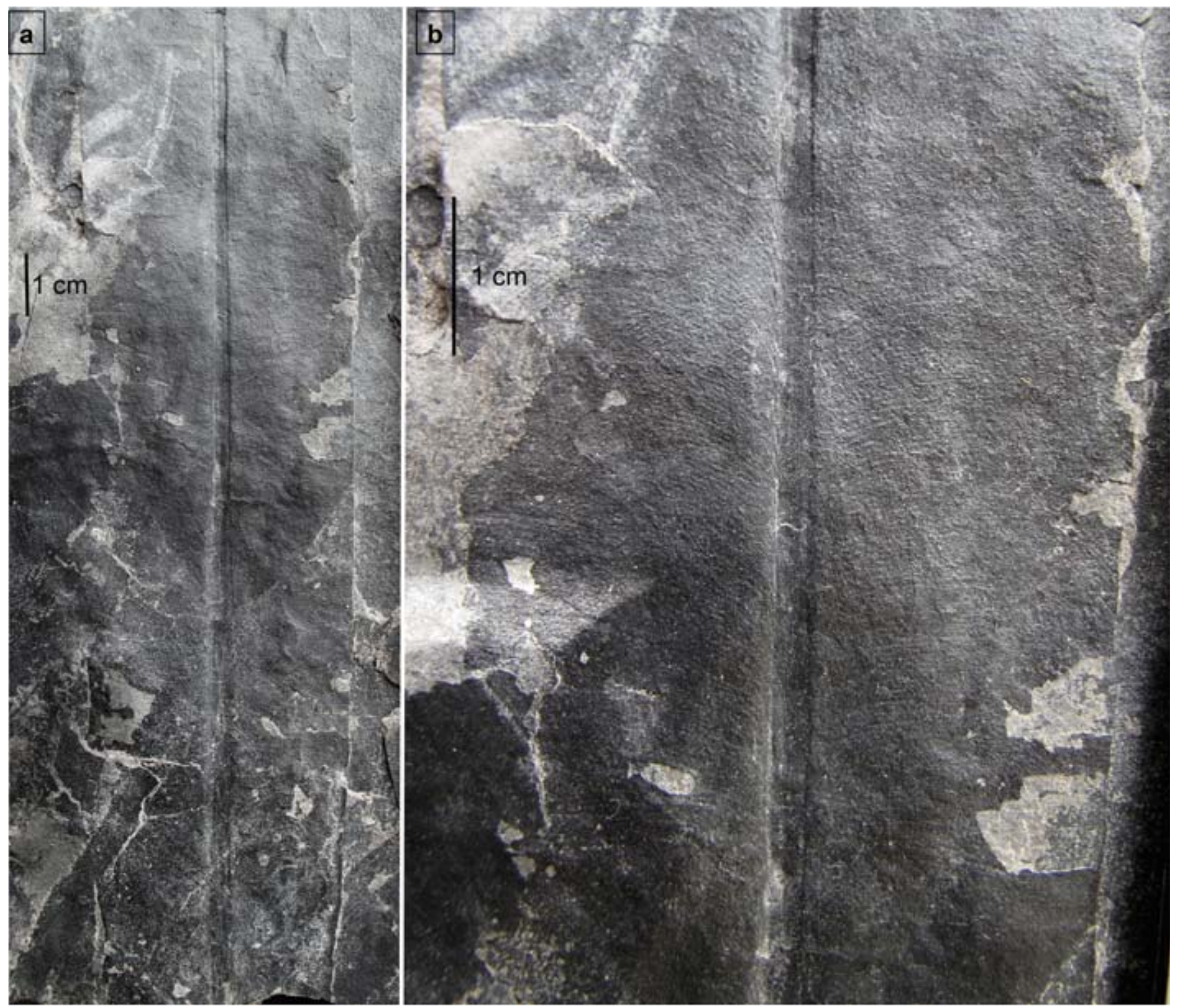

Figure 11. Taeniopteris multinervia, USNM specimen 558427. a) Main portion of lamina showing thick midvein and parallel leaf margins. b) Closeup of lamina showing horizontally disposed secondary veins through most of the lamina.

for multiple (commonly two) veins to enter the lamina. The pinnule lamina can be several times broader than the basal attachment point, or can remain narrow and only slightly expanded despite having several lobes. The venation is open-dichotomous, moderately dense due to multiple forks, relatively straight, and steeply ascending. Where seen, pinnae are topped by a fan-shaped terminal pinnule with shallow rounded teeth. The terminal pinnule may be partially fused to one or two subjacent lobed pinnules.

The affinity of these specimens cannot be confirmed from the present material, but we lean toward assignment to Sphenopteridium. As discussed by Mamay (1992), Sphenopteridium generally is considered a Mississippian genus that contains many species, and Mississippian forms have been interpreted as characteristic of relatively dry substrates in seasonal precipitation regimes. Specimens from the Brazil Formation are subtly different from $S$. manzanitanum, which is of Late Pennsylvanian (Missourian/Kasimovian) age (Lucas et al., 2011), based on the presence of teeth at the ends of some pinnules and the more steeply oblique laminate surfaces.

Sphenopteris germanica is another possible identification. The distribution of this plant is primarily Permian (Remy, 1978), being widespread in Europe and into Cathaysia. Sphenopteris germanica shares many characteristics with Sphenopteridium, especially similarities among the pinnules and the presence of horizontally borne sclerotic plates on the rachises. Likewise, S. germanica also has been suggested to preferentially occupy periodically moisture-deficient 

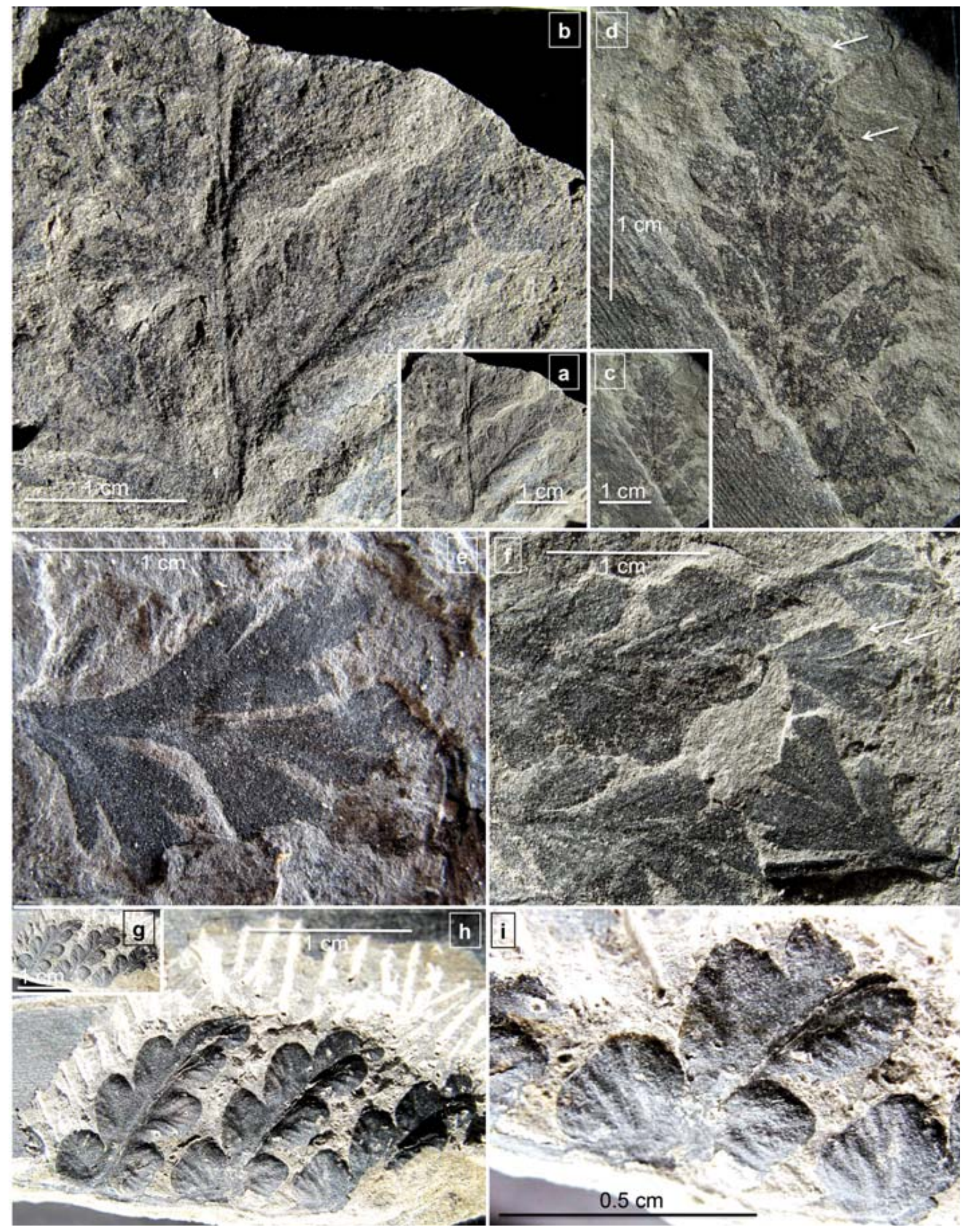
substrates in mesic, but seasonally dry habitats (Barthel, 2006; Dimitrova et al., 2011). Similarities in the foliar morphology of Sphenopteridium manzanitanum and $S$. germanica led DiMichele et al. (2013), in a reexamination of the Kinney Clay Pit flora, the type locality of $S$. manzanitanum, to suggest generic identity and the transfer of S. germanica to Sphenopteridium, although this was not formally accomplished. If the inferred associations or observed attachments between reproductive organs and foliage are considered, such identity may not be warranted (see below).

Specimens described herein fall between the primary stratigraphic ranges of the two most probable candidates for generic affinity. Specimens attributed to Sphenopteridium from elsewhere, but so poorly preserved that they also could be assigned to Sphenopteris germanica, have been reported from biostratigraphically well constrained (conodonts and fusulinids) upper Middle Pennsylvanian (upper Desmoinesian, upper Moscovian) strata in New Mexico (Lucas et al., 2013; fig. 12.2). Similarly, specimens of uncertain, but possibly Middle Pennsylvanian, strata have been reported from Colorado (Pfefferkorn \& Resnik, 1980), where they were initially attributed to the Permian due to the typical range of $S$. germanica in Europe. In both cases, the depositional settings are suggestive of seasonal moisture deficits, as also inferred for the Late Pennsylvanian occurrence of $S$. manzanitanum in New Mexico (Mamay, 1992). Therefore, from a stratigraphic perspective, one may infer that the Middle Pennsylvanian occurrence documented herein is a Lazarus-taxon anomaly, i.e., a taxon appearing well above its most commonly developed range (see Mamay, 1992). As Wagner (2001) pointed out, several Mississippian taxa extend into the Pennsylvanian in moisture-stressed habitats, so such a late occurrence is not unprecedented in taxonomic or stratigraphic context. In contrast, this occurrence could be what Looy et al. (2014a) termed a Methuselah-taxon anomaly, i.e., a taxon appearing well before its documented stratigraphic range. In either case, the preservational restrictions imposed on organic matter in seasonally dry habitats lie at the root of such anomalous occurrences.

Perhaps the most compelling reason for assignment to Sphenopteridium sp. is based on reproductive evidence, albeit weak, given that no macroflora fructifications of probable association with the vegetative remains were identified in the collections. Nonetheless, palynology may shed some light on the matter of identification. Sphenopteris germanica has been correlated with the reproductive organ Schuetzia anomala Geinitz, which produces the pollen types Wilsonites and Guthoerlisporites (Remy \& Rettschlag, 1954). In contrast, Sphenopteridium has been inferred to produce the reproductive organ Telangiopsis Eggert \& Taylor (see Mamay, 1992, p. 1099), from which trilete microspores attributable to Punctatisporities have been macerated (Eggert \& Taylor, 1971).

Wilsonites is abundant in some Upper Pennsylvanian strata in the USA, mainly from non-coaly intervals, and rarely extends down into the Middle Pennsylvanian (Peppers, 1997). Thus, as suggested by Dimitrova et al. (2011), it appears that the parent plant, Sphenopteris germanica, was present as far back as the Middle Pennsylvanian, even if only rarely found as a macrofossil. Nonetheless, neither Wilsonites nor Guthoerlisporites were present in any samples from the study localities. In contrast, six species of Punctatisporites occur in the macerations. Punctatisporites minutus is the most common palynomorph in the macerations, although it is attributed to the marattialean tree ferns, whereas the other five species of Punctatisporites are individually present in low abundance and generally have been attributed to nonmarattialean ferns. Could one of these spores be derived from Sphenopteridium? Although plausible, due to the cross-taxonomic-class pattern of occurrence at the generic level, the presence of Punctatisporites cannot be used to confirm the presence of Sphenopteridium. On the whole, the absence of pollen from Sphenopteris germanica, in addition to the known occurrences of Mississippian plants in Pennsylvanian dryland habitats, has us leaning toward assignment of the specimens to Sphenopteridium.

\subsubsection{Karinopteris $s p$. or Eusphenopteris $s p$.}

One small, fragmentary specimen from the small (14 quadrats) NERCO Midway Mine collection appears to be attributable to either Karinopteris Boersma or Eusphenopteris Simson-Scharold (Figs 12g-12i). The collection otherwise contains only cordaitalean remains. As often happens with small fragments of much larger fronds, identification of this specimen with certainty is not possible, although it is relatively well-preserved. Furthermore, Karinopteris and Eusphenopteris can be difficult to differentiate in fragmentary preservation, as discussed by

Figure 12. a) Sphenopteridium with thin, slightly flexuous rachises, USNM specimen 558448. b) Magnification (x 3 ) of image in Fig. 12a. c) Sphenopteridium pinna end showing pinnule lobing, USNM specimen 616927. d) Magnification (x 3) of image in Fig. 12c showing some pinnules with small terminal teeth (arrows). e) Sphenopteridium pinna tip showing pinnule lobing, USNM specimen 616931. f) Sphenopteridium lobed terminal pinnae/pinnnules, some with small terminal teeth (arrows), USNM specimen 558447. g) Karinopteris sp. or Eusphenopteris sp., USNM specimen 616930. h) Enlargement of image in Fig. 12g showing pinna form, with small terminal pinnules, and prolongation. i) Further enlargement of image in Fig. $12 \mathrm{~g}$ showing the form and venation of the pinnules, including the elongated, lobed oval form of the basiscopic pinnule. 
Boersma (1972). Considering the habitat implications of a seasonally dry setting, and the paleogeographic position, west of the central Pangean mountains, it is possible the specimen represents a new species.

Among the species of Karinopteris described by Boersma (1972), the specimen appears most similar to $K$. soubeiranii (Zeiller) Boersma. Among the many species of Eusphenopteris species as delimited by van Amerom (1975), the specimen is most like those in Section Striata, which includes E. laxifolia Amerom, E. scribanii Amerom, E. striata (Gothan) Novik, and an intermediate form that van Amerom (1975) referred to as E. scribaniistriata. Karinopteris is present elsewhere in Euramerica within the stratigraphic interval in question, as are species of Eusphenopteris, including members of Section Striata.

The specimen consists of at least three ultimate pinnae that are approximately $1.5 \mathrm{~cm}$ long, attached to a thin, $<1 \mathrm{~mm}$ wide, slightly flexuous rachis. Each pinna consists of six pinnules, three on each side, with subalternate insertion. The basalmost, basiscopic pinnule is ovoid in shape and slightly bilobed, up to $4.2 \mathrm{~mm}$ in its greatest dimension. The other pinnules have an acroscopically directed triangular shape, with a rounded to bluntly acute apex, somewhat curved lateral margins, and broad attachment to the ultimate pinna rachis. Pinnules diminish in size upward, and are closely spaced, weakly decurrent and confluent. Terminal pinnules are elongate and asymmetrical. Exposed in adaxial view, the surface is not finely striate, as is characteristic of Eusphenopteris striata. One vein enters the base of each pinnule and forms a vaguely marked and slightly sunken midvein, a feature that, together with inrolled pinnule margins, points to slightly vaulted pinnules. The venation is coarse and opendichotomous; up to three sets of lateral veins depart from either side of the midvein and fork once.

\subsubsection{Linopteris neuropteroides}

Three isolated pinnules of neuropteroid aspect, but with reticulate venation, were found at the Brazil Coal and Clay and Comet Coal and Clay localities. The pinnules are most similar to Linopteris neuropteroides (Gutbier) Potonié, being ovoid to slightly falcate with straight sides, and having a rounded base and rounded apex (Figs 13a-13b). The midvein is weak but extends over half the pinnule length. The lateral venation is initially open-dichotomous, arching at $45^{\circ}$ or greater, asymmetrical (steeper on the basiscopic side), and becoming lower angle through the vein trajectory. The lateral venation is markedly reticulate but with elongate vein meshes, so that the reticulations are not always obvious on casual observation.

Linopteris neuropteroides is a long-ranging species, extending through much of the Pennsylvanian. Most reports of the taxon illustrate elongate, relatively narrow, falcate pinnules, which are often attributed to L. neuropteroides forma major (e.g., Šimůnek, 2008; Libertín et al., 2009; Bashforth et al., 2011; Wagner \& Castro, 2011). Wagner \& Álvarez-Vázquez (2010) questioned identifications from strata older than the upper Asturian and assigned such specimens to Linopteris cf. neuropteroides (see their pl. $\mathrm{X}$, fig. 1), suggesting that $L$. neuropteroides sensu stricto occurs from the upper Asturian to the Stephanian C in Europe (Wagner \& Álvarez-Vázquez, 2010). Specimens in our collections are similar to the form attributed to $L$. cf. neuropteroides by Wagner \& Álvarez-Vázquez (2010), given their blunt shape and the low angle with which the lateral veins reach the pinnule margin. However, the stratigraphic position of the study specimens, equivalent to the lower Asturian, argues for assignment to forma typica, although the small sample size limits knowledge of the range of variation.

The presence of Linopteris neuropteroides in cordaitalean-dominated assemblages may have ecological implications. For example, Libertín et al. (2009) noted that L. neuropteroides is associated with cordaitaleans in slope habitats in a Lower Pennsylvanian intramontane basin in the Czech Republic. Bashforth et al. (2011) also reported the plant to be common in well-drained streamside settings in late Middle Pennsylvanian riparian habitats, which also were occupied by cordaitaleans and lobatopterid tree ferns, an assemblage similar to that reported here and of only slightly younger age. Furthermore, Zodrow \& Cleal (1993) suggested that reticulate venation may have contributed to drought tolerance in pteridosperms.

\subsubsection{Fern foliage of uncertain affinity}

Two forms of fern-like foliage possibly attributable to the marattialean ferns were identified in the collections, one a lobatopteroid and the other more typically pecopteroid. Found at low frequencies, both types occur at the Log Cabin Coal Company, Ashboro/46 Pit, whereas only the lobatopteroid occurred at the Northern Coal Company, New Britton Pit. The latter collection contains a substantial range of variation that captures intergradations among a variety of pinnule shapes (see Wagner, 1958; Wittry et al., 2014). This range of variation is so great that fragmentary, isolated specimens would be difficult to link together with confidence. Consequently, it is possible that specimens identified as Pecopteris sp. from the Log Cabin locality (Bashforth et al., 2016b) are part of the range of morphology of the lobatopteroid from that location, which Bashforth et al. (2016b) assigned to cf. Crenulopteris acadica (Bell) Wittry, Glasspool, Béthoux, Koll \& Cleal.

Although the range of variation at the Northern Coal locality is similar to that of a lobate pecopterid, assignment to Lobatopteris Wagner, or the segregate Crenulopteris, is equivocal. It is possible that this suite of foliage belongs 


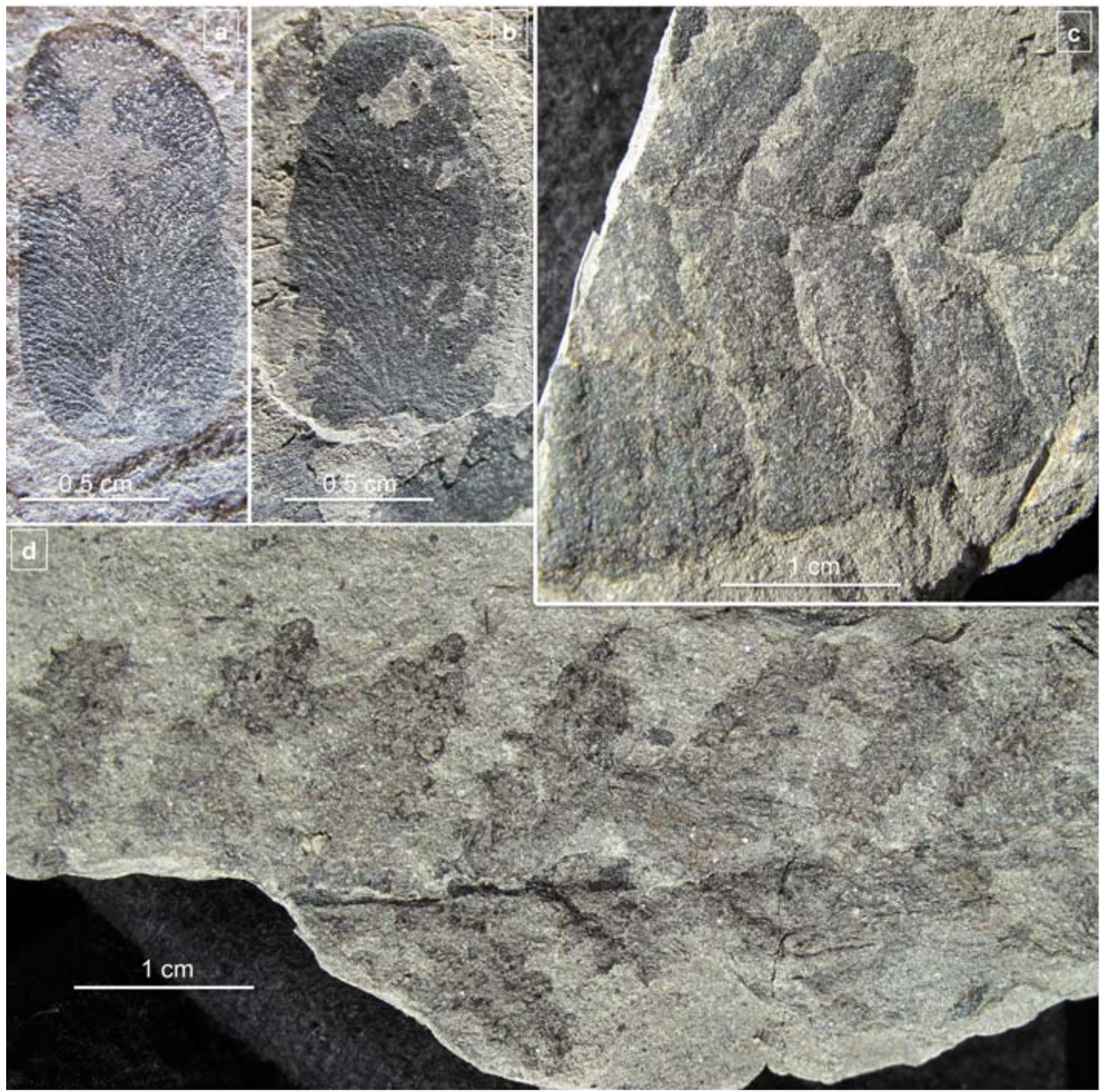

Figure 13. a) Linopteris neuropteroides pinnule, USNM specimen 558435. b) Linopteris neuropteroides pinnule, USNM specimen 558436. c) Lobatopteroid series 1 of 4 (same magnification), pinnules with undulate lamina and slight marginal crenulations, USNM specimen 558445. d) Lobatopteroid series 2 of 4 (same magnification), pinnules with deeper marginal lobes, about half the pinnule width; this possibly fertile specimen may indicate affinity of this entire series of foliage morphologies with Zeilleria avoldensis, USNM specimen 616928.

to a sphenopterid fern, possibly Zeilleria avoldensis, an identification suggested to us during review. Unfortunately, the coarseness of the sedimentary matrix and the evident thinness of the pinnule laminae have obscured details of the fine venation and of possibly attached reproductive organs. Figure $13 \mathrm{~d}$ in particular may be a fertile specimen and, if so, the sporangia appear to be borne marginally and to be of a type similar to that of $Z$. avoldensis (see Brousmiche, 1983) rather than of a form typical of marattialeans.

We thus restrict our identification to the status of "lobatopteroid fern" recognizing the high likelihood of conspecific status with the specimen identified by Bashforth et al. (2016b) as cf. Crenulopteris acadica from the Log Cabin locality. Taxonomic issues surrounding the 
identification and classification of marattialean foliage have been discussed recently by Wittry et al. (2014) and Cleal (2015).

Four stages of lobatopteroid morphology are illustrated at the same magnification (Figs 13c-13d; Fig. 14). Lateral veins are not observable due to the grain size of the matrix. The largest pinnules, with a slightly lobate margin (Fig. 13c), are characterized by non-decurrent, well-marked midveins and straight sided, blunt tipped laminae with slightly constricted bases. Laminae are undulatory, the undulations conforming to the slight marginal crenulations. The basal crenulations are deeper and more distinct than those higher along the lamina. Pinnules are inserted oppositely, inclined acroscopically, closely spaced, and may touch or even overlap their neighbors. More lobate, elongate pinnules (Fig. 13d) retain the wide central part of the lamina, but have clearly developed marginal lobes and a distinct, small, rounded terminal pinnule. This morphology transitions to forms with deep marginal incisions (Fig. 14a), such that they may be described as intermediate between large lobed pinnules and ultimate pinnae with small, confluent, rounded pinnules. In the specimen with this morphology, the pinnule midvein is decurrent (Fig. 14b, at arrows). Where the frond comprises pinnae with free pinnules (Fig. 14c), pinnules are small, straight-sided with rounded apices, and broadly attached to the rachis, with attachment becoming progressively more constricted basiscopically along the rachis. In such pinnules, and pointing toward their lobatopteroid affinities, the midvein is slightly decurrent. The pinna apex is terminated by a small, rounded terminal pinnule that is partially adherent to the subjacent pinnules.

\subsubsection{Senftenbergia plumosa}

Senftenbergia plumosa (Artis) Stur emend. Bek \& Pšenička is the most common Asturian species of this longranging (Mississippian-Permian) genus (Bek \& Pšenička, 2001; Wagner \& Álvarez-Vázquez, 2010). The plant is considered to be an early member of the extinct fern order Zygopteridales, based on the morphology of its sporangia, which have an apical annulus (Jennings \& Eggert, 1977); the genus has been assigned to the family Tedeleaceae (Bek \& Pšenička, 2001; Phillips \& Galtier, 2005). Bek \& Pšenička (2001) revised the diagnosis of Senftenbergia plumosa, and provided a comprehensive review of the history of the genus, the species involved, and their spores.

All specimens in the collections come from the Nancy Coal Company, Sugar Creek Mine, where they occur at a frequency of nearly $10 \%$. Spores of the Raistrickia type, produced by Senftenbergia, are noted at four of six localities. Raistrickia reaches abundances of $0.4 \%$ in samples from the Nancy Coal Company and NERCO localities in Daviess County, whereas the spore is "present" (but uncounted) in samples from two other localities based on scans of the prepared slides. No macroscopic reproductive organs were encountered.

The vegetative morphology of specimens assigned to Senftenbergia plumosa is typical of the species (Figs 15a-15c). Pinnules are distinctively triangular and small, ranging from 2 to $3 \mathrm{~mm}$ in length and $<1.5 \mathrm{~mm}$ in width; they may be acroscopically inclined. Attachment to the rachis is broad and non-constricted, with some pinnules being confluent. Apices are sharply to bluntly acute. The midvein is well marked and extends to the apex of the pinnule. Lateral veins are simple, although some veins appear to thicken near the margin as if an incipient dichotomy were present. Lateral veins are mostly straight, but the most proximal acroscopic vein may be distinctly concave upward, a feature that is more subtle in more distal acroscopic veins. Pinnae may be relatively long compared to the size of the pinnules, and are alternately inserted. One specimen in the collection appears to be a rachis that bears palmate laminate appendages with distinctly elongate, attenuate lobes with acute apices. This specimen is interpreted to be the principle rachis of S. plumosa that bears aphlebia, which occur at the base of the secondary rachises/pinnae (see Bek \& Pšenička, 2001, fig. 2).

\subsubsection{Sphenopteris}

Small, sterile fern foliage is frequently referred to Sphenopteris (Brongniart) Sternberg, a rather meaningless genus with a long stratigraphic range that encompasses probable seed plants (e.g., Sphenopteris germanica) and a vast array of ferns of various types (see Brousmiche, 1983). Pennsylvanian-age fern foliage assigned to Sphenopteris is widely variable in form, but generally consists of small pinnules with simple venation, with which the two tiny specimens from the Northern Coal Company, Britton Pit locality accord. Pinnules are $<2 \mathrm{~mm}$ long and wide, and broadly attached to the rachis. They have slightly dentate or crenulate margins, decurrent and angular midveins, and simple, sparse, lateral veins. Meaningful identification is not possible given the minute size of the fragments, and the coarse-grained matrix likewise precluded informative illustration. For future reference, one specimen (USNM 616936) is housed in the NMNH collections.

\subsubsection{Calamitaleans}

The calamitaleans are among the most iconic of Pennsylvanian wetland plants. Their wide distribution includes, however, both wetland and seasonally dry landscapes, probably reflecting the combination of sexual and vegetative reproduction that characterizes the life history of many taxa. Detailed studies of the group (e.g., Barthel, 2004; Rößler \& Noll, 2006) have 


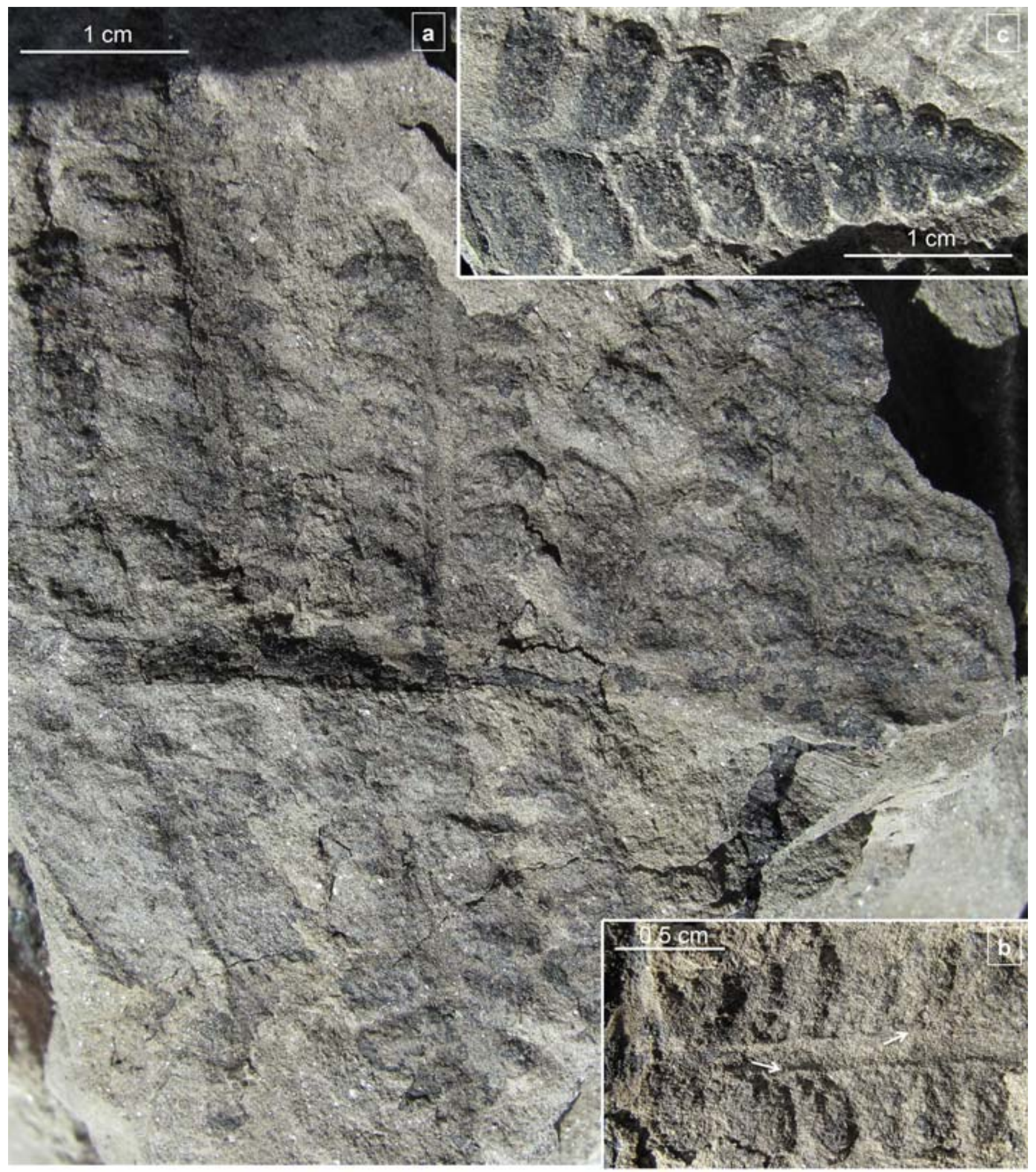

Figure 14. Lobatopteroid series continued. a) 3 of 4 (same magnification), pinnules clearly individuated with slightly confluent bases and decurrent midveins, USNM specimen 558444. b) Closeup of a pinna showing decurrent pinnule midveins (arrows), USNM specimen 558444. c) 4 of 4 (same magnification), pinnae tip with clearly individuated, free pinnules, those near the base showing slight marginal waviness, USNM specimen 558443. 
revealed much greater morphological diversity than is generally appreciated. Many of the smaller forms typical of aggradational settings, such as stream sides and bars within active streams (Falcon-Lang, 2015), were small with minimal wood, whereas other forms, perhaps growing in more stable settings (Rößler, 2006), were enormous and had thick secondary xylem. Forms found in the present collections probably were small with minimal wood development. Although preserved in a manner that has frequently been coined "pith casts", the calamitalean remains almost certainly represent casts of the full axis (DiMichele \& Falcon-Lang, 2012; Falcon-Lang, 2015). Calamitalean remains are not common in the study collections. Stems, foliage or reproductive organs were identified in 10 quadrats, at a frequency of $4 \%$. The greatest diversity of remains was found at the Log Cabin Coal Company Ashboro/46 Pit (Bashforth et al., 2016b), including single specimens of Calamites Brongniart (stem), Annularia sphenophylloides (Zenker) Gutbier (foliage), and Calamostachys Schimper (strobilus). Calamites stems (Fig. 15d) also occur at the Northern Coal Company, New Britton Pit and Nancy Coal Company, Sugar Creek Mine localities.

Three foliar specimens of uncertain affinity occur in the Nancy Coal Company, Sugar Creek Mine collection (Fig. 15e). The leaf whorls are similar to Annularia sphenophylloides, the leaves being spathulate. However, the whorls do not have the circular symmetry typical of the species, and are somewhat larger than usually found. Affinities with Annularia radiata (Brongniart) Sternberg or Annularia spinulosa Sternberg, which have elongate fusiform leaves that taper to an acute apex, can be ruled out. The specimens are similar to calamitalean foliage with larger spathulate leaves that generally is attributed to Annularia stellata (Schlotheim) Wood (a junior synonym of A. spinulosa - see Barthel, 2004), a taxon that probably needs a new name or may conform to a disused name.

\subsubsection{Incertae sedis $A$}

One specimen (part and counterpart) of an enigmatic plant of indeterminate affinity occurs at the Log Cabin Coal Company, Ashboro/46 Pit, at the northern end of the outcrop belt. The material was discussed at length by Bashforth et al. (2016b), and thus will only be treated briefly here (Fig. 15f).

The specimen consists of a broad central axis, up to $18 \mathrm{~mm}$ in width, that bears coarse longitudinal striations. Narrow, linear appendages, inserted at approximately $45^{\circ}$, are borne laterally along the axis in opposite to subopposite arrangement. The lateral appendages are confluent with and broadly attached to the main axis, from which multiple veins enter their laminae. The venation parallels the lateral margins of the appendages. Laminae are decurrent in attachment to the main axis, and the acroscopic side is slightly constricted. The appendages may exceed $4 \mathrm{~cm}$ in length, with widths reaching $8 \mathrm{~mm}$. The appendages may have been relatively thick in life, indicated by a thin wafer of sediment between the adaxial and abaxial surfaces, possibly implying a succulent habit.

The affinities of this plant were considered in detail by Bashforth et al. (2016b), although positive determination could not be made. The closest similarities were considered to be with Noeggerathialeans of various types, or possibly with broad-leaved conifers of the Podozamites Braun type, although numerous other possibilities were evaluated. A plant of uncertain affinity, but of nearly identical morphology to Incertae sedis A, was illustrated by Wagner (in van Loon, 1971, pl. 8, fig. 7) and identified as "?Pterophyllum", but without further discussion. Interestingly, this is the same flora, from upper Westphalian strata of northwestern Spain, from which Taeniopteris (possibly Lesleya) also was identified (noted above), and in which Linopteris neuropteroides is abundant.

\subsubsection{Incertae sedis $B$}

Two laminae, hereafter referred to as pinnules, of indeterminate affinity were identified from the Nancy Coal Company, Sugar Creek Mine locality. Neither is complete, with both missing their base, but one specimen is almost complete; the description will focus on this specimen (Fig. 15g).

The pinnule is approximately $3 \mathrm{~cm}$ in length and 1.4 $\mathrm{cm}$ in maximum width, which occurs at about $30 \%$ of the distance from the presumed base. The rounded base gradually constricts asymmetrically from the widest point. The distal $60 \%$ of the lamina gradually constricts toward the triangular and acute apex. The lateral pinnule margins are asymmetrically curved, one side being weakly concave and the other weakly convex. A strongly marked midvein extends from the base to apex of the pinnule, and given that the midvein is slightly protuberant, the exposed surface probably is abaxial. The lateral venation is open-dichotomous and well marked, with the veins being widely spaced, as much as $0.8 \mathrm{~mm}$ apart in portions of the outer lamina. The secondary veins depart from the midvein at an acute angle of $20^{\circ}$ or less, reaching about a $45^{\circ}$ angle with the midvein before turning upward very slightly as the vein reaches the lateral margin; this upturning is more conspicuous on the side of the pinnule with a concave margin, which may be the acroscopic side. Although difficult to discern, lateral veins may fork equally immediately after arising from the midvein, branch again dichotomously within $2 \mathrm{~mm}$ of the midvein, and at least once more within the inner $1 / 3$ of their trajectory; a few of the longest veins may fork again close to the leaf margin. A 


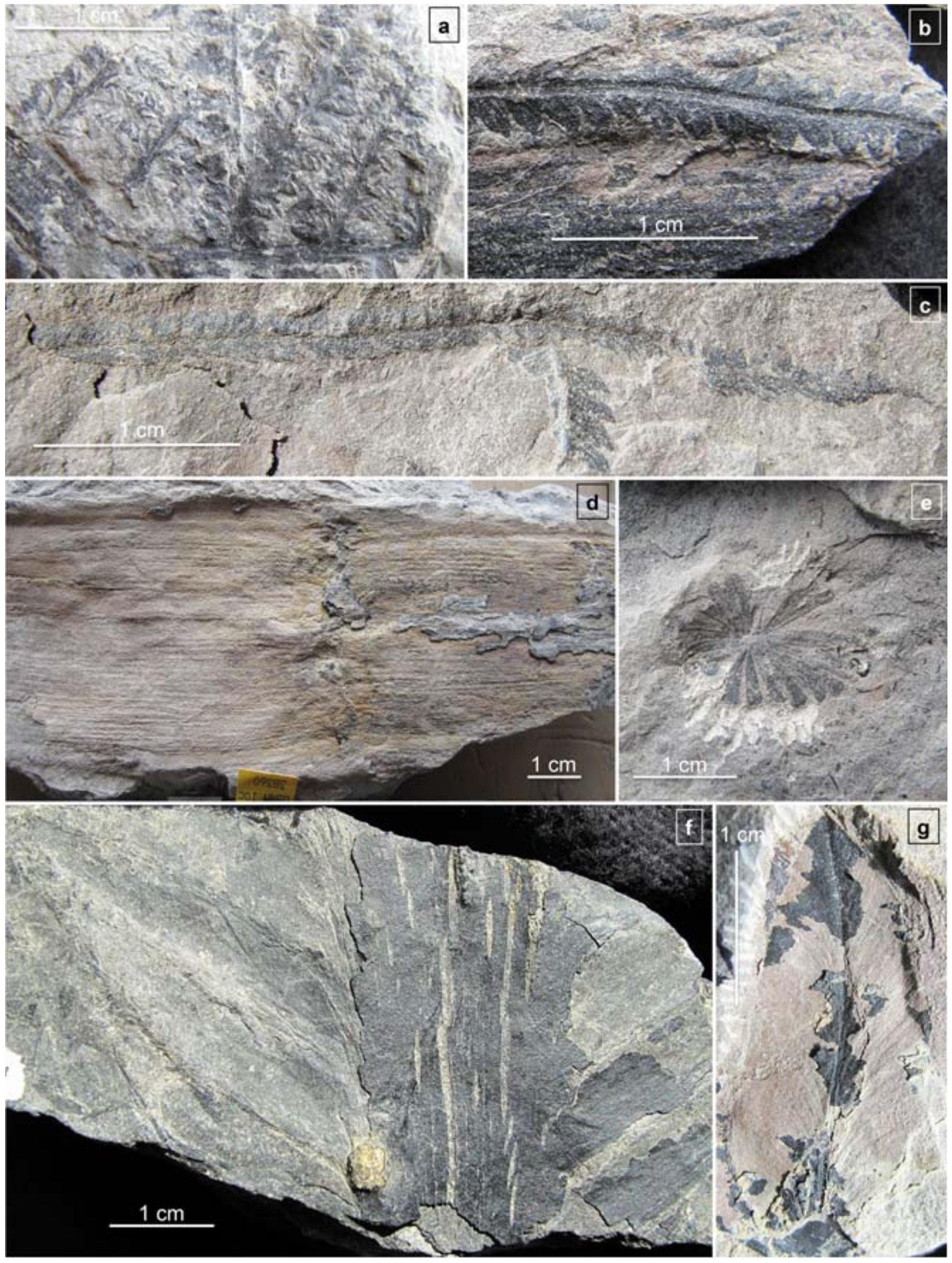

Figure 15. a) Senftenbergia plumosa, pinnule venation clearly visible, USNM specimen 558431. b) Senftenbergia plumosa, triangular to falcate pinnule shape and wide pinna rachis, USNM specimen 558430. c) Senftenbergia plumosa, elongate terminal pinna and strongly falcate pinnules, USNM specimen 558429. d) Calamites sp., USNM specimen 558422. e) Annularia sp., USNM specimen 558423. f) Incertae sedis A, USNM specimen 606707. g) Incertae sedis B, USNM specimen 558421. 
minor amount of organic material adheres to the specimen surfaces, but neither compressions of the presumed abaxial surface nor impressions of the adaxial surfaces beneath them reveal any indication of surface hairs or glands.

We know of no specimens that resemble these pinnules from any documented Pennsylvanian flora. They bear no features that point unequivocally to fern or seed plant affinity. The sparse, open-dichotomous, and weakly S- or epsilon-shaped lateral venation, and the strong midvein that extends to the pinna tip, are reminiscent of the Permian plants Protoblechnum Lesquereux (sensu Halle), Supaia White, Glenopteris Sellards and Compsopteris Zalessky emend. Naugolnykh. However, pinnules in these taxa are somewhat longer and narrower than in the study specimens, and none have rounded, constricted pinnule bases. Given the lack of clear affinity, even at the level of Class rank, the specimens are assigned to Incertae sedis, either Filicopsida or Spermatopsida.

\subsection{Macrofloral quantitative composition}

A total of 319 hand-sample surfaces were examined. Nineteen barren or counterpart surfaces were excluded from further analysis, leaving 300 fossiliferous faces (= sampling quadrats) on which the quantitative analysis was based. The results reported below are divided into dryland and wetland taxa. With the exception of lobatopteroid fern foliage, Linopteris neuropteroides (a pteridosperm) and calamitalean stems, all wetland elements are confined to single site occurrences, and all at $<10 \%$ frequency where they occur.

With the exception of the ferns Sphenopteris spp., represented by two specimens at the Northern Coal Company, Britton Pit and Senftenbergia plumosa, common at the Nancy Coal Sugar Creek Mine, all taxa probably had an arborescent growth habit. A possible exception is Sphenopteridium sp., which may have had a cormose or bulbous stem with a low, but central growth habit (the juvenile plant described by Ash \& Tidwell (1986) as Arnoldia kuesii may be Sphenopteridium manzanitanum Mamay and is similar in growth form to much larger specimens of that species found recently). Groundcover plants may be undersampled due to protection from wind and because leaves generally are not abscissed (Scheihing, 1980). The collections from which groundcover taxa were recorded are relatively large ( $n=56$ and $n=72$ quadrats), perhaps increasing the chances of encountering these lowstature plants. Groundcover also may have an extremely patchy distribution, even if diverse, as demonstrated by Opluštil et al. (2009a) for Middle Pennsylvanian swamp vegetation preserved in situ under volcanic ash.

Results of the quantitative analyses are presented in Table 1, which is organized by locality. The table shows the number of quadrats (sample surfaces) on which each taxon was identified, and the percent frequency of occurrence in that sample. The results are compiled and simplified for comparative purposes, where rankings of taxa in the entire suite of samples are presented in three ways: (1) by number of site occurrences, (2) by mean of the individual site mean frequencies, and (3) by mean frequency in the total quadrat sample with all sites combined. A fourth category also is presented, in which the taxa are ranked by the average rank of the three different ranking methods.

\subsubsection{Dryland taxa}

By all three means of assessing dominance (Table 2), cordaitalean foliage was overwhelmingly the most important plant type, occurring at all six localities, at frequencies ranging from 55.6 to $100 \%$ of the quadrats sampled at an individual site, with mean frequencies of occurrence of $78.7 \%$ based on the combined sample, and $82.0 \%$ based on the mean of the site means. Cordaitaleans had the highest frequency of occurrence at five of six localities, only ranking behind Lesleya sp. at the Brazil Coal \& Clay site. Cordaitalean leaves were commonly preserved in dense mats, generally randomly oriented but clearly (current?) aligned in some instances. Platyspermic winged seeds about $8 \mathrm{~mm}$ in diameter, probably attributable to cordaitaleans, also occurred at five of six localities at frequencies ranging between $1.2 \%$ and $10.8 \%$. At the Brazil Coal and Clay locality in Clay County, an unusually large, winged platyspermic seed $>1 \mathrm{~cm}$ in diameter occurred as a single specimen, possibly derived from a cordaitalean.

Foliage of Lesleya sp. was second in importance to that of cordaitaleans (Table 2). These distinctive leaves were identified at four sites throughout the outcrop belt. Frequencies ranged between $26.5 \%$ and $73.2 \%$, mean occurrence was $34.3 \%$ of the combined sample, and mean of the site means was $33.0 \%$. Lesleya sp. leaves were the most frequently encountered plant fossils at the Brazil Coal \& Clay mine. Some occurrences of Lesleya sp. may have been missed in the quantification process, and its frequency of occurrence at any site thus underestimated. This potential sampling error reflects the fact that small fragments of Lesleya leaves can appear parallel veined, and thus be mistaken for Cordaites. Distinctive seeds, possibly attributable to the Lesleya plant, were found at the Brazil Coal and Clay mine, where Lesleya was the most common taxon identified. These seeds (frequency of $17.8 \%$ of the sampling quadrats from the site) are round and about $8 \mathrm{~mm}$ in diameter, flattened but thick, and generally vitrinized.

Taeniopteris sp. cf. T. multinervia is the third most important element of the flora based on its mean frequencies of occurrence: $6.3 \%$ of the quadrats in the combined sample, and $4.3 \%$, mean of the mean site occurrences (Table 2). However, the taxon was only identified at two of six localities, giving it a smaller number of site occurrences 
than calamitalean remains, specifically those of Calamites sp. stems. However, the two occurrences, at Log Cabin Coal Company Ashboro/46 Pit in Clay County and Nancy Coal Company, Midway Mine in Daviess County, are at opposite ends of the geographic area studied, indicating the possibility of widespread landscape coverage. More than any other taxon, the frequency of occurrence of Taeniopteris sp. cf. T. multinervia probably is underestimated by all means of measuring frequency, as small fragments of Taeniopteris lamina with no preserved midvein can be confused for equally small Cordaites fragments. Likewise, Taeniopteris easily may be confused with Lesleya if the venation is poorly preserved, because both taxa have large, tongue-shaped leaves and relatively dense, open dichotomous venation (see Bashforth et al., 2016b).

The last quantitatively significant dryland plant represented is Sphenopteridium sp., which was found at two localities, and thus similar to Taeniopteris in its percentage frequency of occurrence; the mean frequencies of occurrence are $3.7 \%$ of all sampling quadrats and 4.2 $\%$, mean of mean occurrences (Table 2). At the two sites, Sphenopteridium sp. is present at $15.4 \%(\mathrm{n}=72$ quadrats) and $10.0 \%(n=10$ quadrats, a small sample where it occurs as a single specimen). The taxon was only recorded in Greene County, at the Northern Coal Company, New Britton Pit and Comet Coal and Clay Company, in the middle part of the study area, and thus has no overlap with occurrences of Lesleya or Taeniopteris.

Two additional elements of unknown affinity, but presumably with dryland habitat preference, were identified in the collections, each found at a different single site where they were represented by one or two specimens. The first, described in detail by Bashforth et al. (2016b) from the Log Cabin, Ashboro/46 Pit locality, is a large, planate, coriaceous organ, probably a leaf bearing parallel-veined pinnules. It is identified herein as Incertae sedis A. The second enigmatic specimen from the Nancy Coal Company locality, is a small, pinnule-like structure of neuropteroid or supaioid form, but with a venation and size that apparently does not conform to either of these groups. It is referred to herein as Incertae sedis B. There probably were a variety of plants in seasonally dry habitats that are poorly understood or awaiting discovery, given the overall preservation bias against plants in such environments, combined with the general bias towards plants growing in riparian settings.

\subsubsection{Wetland taxa}

The most common wetland taxa are calamitalean sphenopsids, which occur at three localities and are represented by Calamites stems, two types of foliage (Annularia sphenophylloides and Annularia sp.), and a single specimen of Calamostachys. Each foliage taxon occurs at a single but different locality. Calamites and Annularia sp. are represented by multiple specimens at the
Nancy Coal Company mine in Daviess County, the largest of the sampled localities ( $\mathrm{n}=86$ quadrats). Single specimens of A. sphenophylloides, Calamostachys, and Calamites occur at the Log Cabin Ashboro/46 Pit in Clay County, the second largest collection ( $n=81$ quadrats). The maximum frequency of occurrence of any of these taxa at a single site is $3.6 \%$, Calamites stems, which occur at a frequency of $1.7 \%$ of the total combined samples (Table 2).

Ferns also are of local importance at some localities, and encompass all three counties in the study area. Included are a lobatopteroid, probably of filicalean or possibly marattialean affinity (two localities, maximum site occurrence frequency of $7.7 \%$ ) and indeterminate Pecopteris (one locality, $4.2 \%$ ). The zygopteridalean Senftenbergia plumosa was relatively common at one locality, $9.6 \%$, and the likely filicalean remains, Sphenopteris spp., were represented by two specimens at one locality. Pecopteris and the lobatopteroid fern are both present at the Log Cabin Ashboro/46 Pit in Clay County.

Pteridosperm remains are very rare, only present in four sampling quadrats, from two localities. Linopteris neuropteroides occurred twice at the Comet Coal and Clay locality in Greene County, in a small sample of only 10 quadrats. It also occurred as a singleton at Brazil Coal and Clay. As discussed above, this plant may be indicative of periodic moisture stress, rather than the wetland habitats that most neuropteroid species apparently favored. A single specimen of Karinopteris/Eusphenopteris sp. was identified from the NERCO Midway Mine in Daviess County; this small sample ( $n=14$ quadrats) was otherwise entirely composed of cordaitalean remains.

\section{PALYNOFLORA}

Seven samples of shale and mudstone, taken from collections held at the NMNH, Smithsonian Institution, were analyzed for palynomorph content. The samples included one each from five of the six macrofossil collections, the exception being the Log Cabin Ashboro/46 Pit, for which a palynological analysis was presented by Bashforth et al. (2016b). In addition, two "wetland" assemblages were sampled from Comet Coal and Clay, Duke's Pit for the sake of comparison. Recovered spore and pollen assemblages were diverse and contained representatives of all major Pennsylvanian plant groups.

\subsection{Methods}

Each sample was crushed to -60 mesh $(250 \mu \mathrm{m}$ screen openings), and $3.5 \mathrm{~g}$ of powder was immersed in a mixture of hydrofluoric (HF), hydrochloric $(\mathrm{HCl})$ and nitric $\left(\mathrm{HNO}_{3}\right)$ acid to dissolve silicate, carbonate and sulfide minerals. 
Samples were then oxidized with Schulze's solution (nitric acid + potassium chlorate), digested in $5 \%$ potassium hydroxide to remove unwanted organic material, and concentrated using a saturated solution of zinc chloride $\left(\mathrm{ZnCl}_{2}\right.$, specific gravity: 1.9). Amorphous organic matter was removed from the preparations using ethylene glycol monobutyl ether (2-ethoxybutanol), ultrasonic agitation, and short centrifugation. Spore and pollen residues were strew-mounted onto $22 \mathrm{~mm}$ square cover glasses with polyvinyl alcohol. Upon drying, the cover glasses were inverted and fixed to $75 \times 25 \mathrm{~mm}$ glass slides using a synthetic, acrylic resin.

Palynomorph abundances are based on a count of 250 spores/pollen. Additional taxa that were identified, but not counted, are marked with an X in the taxonomic list (Table 3). Several palynomorph taxa are illustrated in Figure 16.

\subsection{Palynofloral composition}

The samples were compositionally diverse, containing lycopsids, ferns, calamitaleans and cordaitaleans (Fig. 17; Table 3). Arborescent lycopsids are represented by Lycospora, Granasporites medius, and Crassispora kosankei, of which Lycospora is most abundant. Small, subarborescent lycopsids are represented by Densosporites, Radiizonates, Cirratriradites, and Endosporites. The presence of Radiizonates difformis is significant because the taxon has a limited stratigraphic range in the Illinois Basin.

Tree fern spores are diverse in the sample set, and range in abundance from 17.6 to $49.6 \%$. Of these, Punctatisporites minutus, Punctatosporites minutus, Laevigatosporites globosus, and Torispora securis are most abundant. Of particular import is the consistent presence of
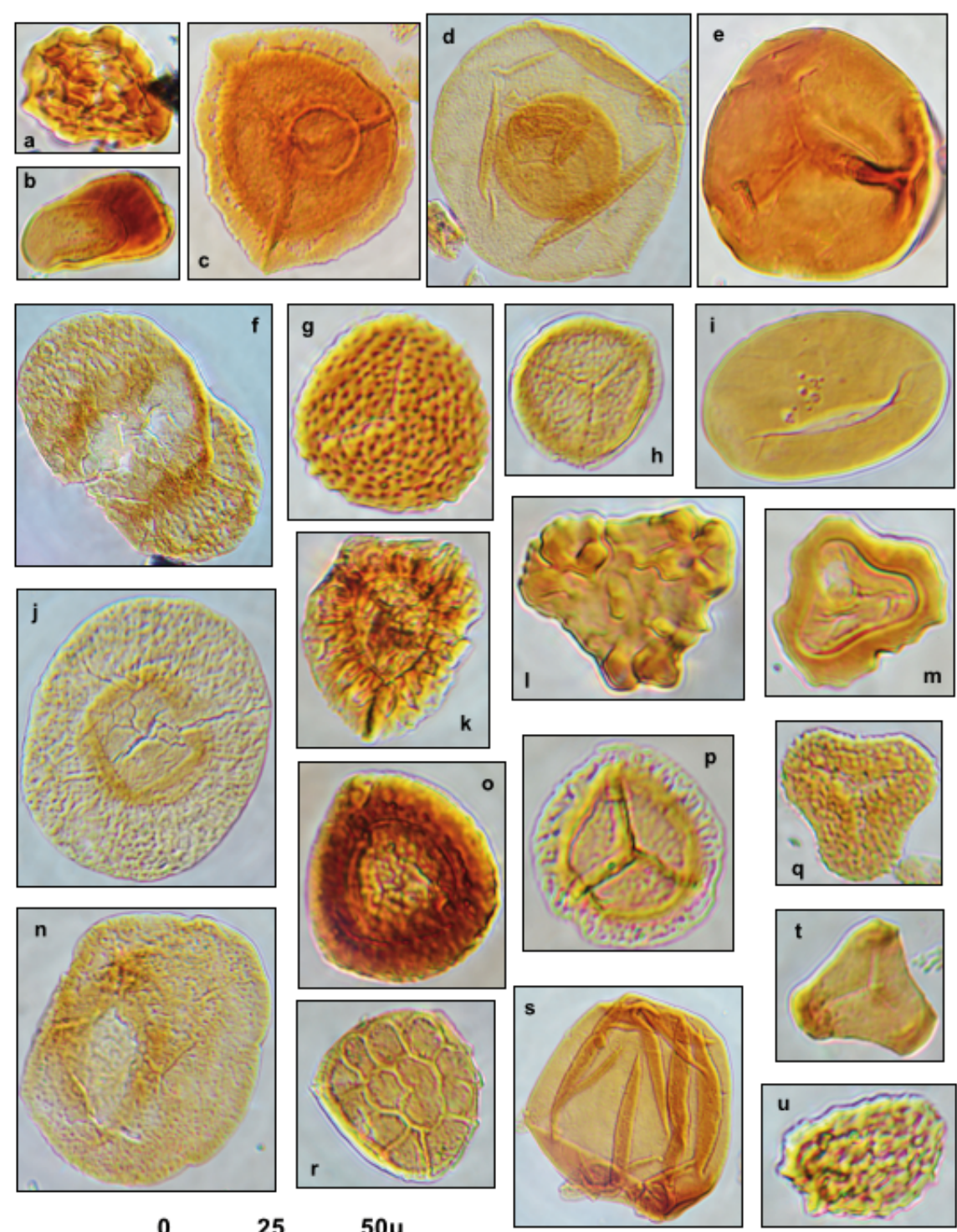

25

$50 \mu$
Figure 16. Examples of selected spores found in the shale macerations, all at the same magnification (scale bar at bottom). a) Thymospora pseudothiessenii. b) Torispora securis. c) Cirratriradites saturni. d) Endosporites globiformis. e) Cadiospora magna. f) Potoniesporites elegans. g) Microreticulatisporites sulcatus. h) Lycospora pusilla. i) Laevigatosporites minor. j) Florinites mediapudens. k) Radiizonates difformis. 1) Triquitrites sculptilis. m) Murospora kosankei. n) Florinites florini. o) Densosporites sphaerotriangularis. p) Lycospora pellucida. q) Lophotriletes commissuralis. r) Dictyotriletes bireticulatus. s) Calamospora breviradiata. t) Triquitrites minutus. u) Thymospora obscura. 
Table 3. Palynomorph abundance in six macerations (KGS Sample ID) of shales and mudstones from six dryland assemblages (USNM Localities 38353, 38878, 43877, 38326, 38360, 38898) and from one wetland assemblage from the same stratigraphic interval (USNM Locality 38325). Palynomorphs are grouped according to taxonomic affinity. Abundances are percentages of in a 250 count sample. $X=$ present in a scan of the sample but not found in the count.

\begin{tabular}{|c|c|c|c|c|c|c|c|}
\hline Coal Mine Name & Log Cabin & Brazil C\&C & $\begin{array}{c}\text { Northern C } \\
\text { Britton Pit }\end{array}$ & $\begin{array}{l}\text { Comet } \\
C \& C(2)\end{array}$ & $\begin{array}{c}\text { Nancy } \\
\text { Sugar Crk. }\end{array}$ & $\begin{array}{l}\text { NERCO } \\
\text { Midway }\end{array}$ & $\begin{array}{l}\text { Comet } \\
\mathrm{C} \& \mathrm{C}(1)\end{array}$ \\
\hline $\begin{array}{l}\text { USNM Locality } \\
\text { KGS Sample ID }\end{array}$ & $\begin{array}{c}38353 \\
\mathbf{3 2 6 3} \\
\end{array}$ & $\begin{array}{c}38878 \\
\mathbf{3 3 8 2} \\
\end{array}$ & $\begin{array}{c}43877 \\
\mathbf{3 3 8 1} \\
\end{array}$ & $\begin{array}{c}38326 \\
\mathbf{3 3 7 8} \\
\end{array}$ & $\begin{array}{c}38360 \\
\mathbf{3 3 8 0} \\
\end{array}$ & $\begin{array}{c}38898 \\
\mathbf{3 3 8 3} \\
\end{array}$ & $\begin{array}{r}38325 \\
\mathbf{3 3 7 7} \\
\end{array}$ \\
\hline Lycospora pellucida & & $\overline{0.8}$ & 3.2 & 1.6 & 3.6 & $\overline{0.4}$ & $\overline{4.0}$ \\
\hline L. pusilla & 0.4 & 2.4 & 6.0 & 2.0 & 1.6 & 1.6 & 5.2 \\
\hline L. granulata & 6.0 & 2.0 & 6.0 & 6.8 & 8.0 & 4.8 & 16.0 \\
\hline L. orbicula & 2.0 & 2.4 & & 0.8 & & & 1.2 \\
\hline L. micropapillata & 2.0 & 4.0 & 3.2 & 6.8 & 3.2 & 1.6 & 4.0 \\
\hline L. rotunda & & & & $x$ & 0.4 & $x$ & \\
\hline Granasporites medius & $x$ & & & 0.8 & 0.8 & 1.6 & $\mathrm{X}$ \\
\hline Crassispora kosankei & $x$ & & & $x$ & & $x$ & \\
\hline Cadiospora magna & & $x$ & $x$ & $x$ & & $x$ & \\
\hline Total Lycopsid Trees & 10.4 & 11.6 & 18.4 & 18.8 & 17.6 & 10.0 & 30.4 \\
\hline Densosporites sphaerotriangularis & 0.8 & & 1.2 & 2.8 & 1.6 & 2.0 & 0.4 \\
\hline D. triangularis & & & $x$ & $x$ & & $x$ & \\
\hline D. intermedius & & & $x$ & $x$ & & $x$ & \\
\hline D. annulatus & & 0.4 & & & & & \\
\hline D. lobatus & $\mathrm{X}$ & & 0.4 & 0.4 & 1.2 & 0.4 & 0.4 \\
\hline Radiizonates difformis & 3.2 & 2.0 & 6.0 & 15.2 & 1.2 & 5.6 & 5.6 \\
\hline Cirratriradites annulatus & & 0.4 & 1.2 & 0.4 & & 0.8 & \\
\hline C. maculosa & & & & & & $\mathrm{X}$ & \\
\hline C. saturni & & & & & & $\mathrm{X}$ & \\
\hline Endosporites globiformis & $x$ & 0.4 & & 0.4 & & 0.4 & 1.2 \\
\hline E. zonalis & & & & & & 0.4 & \\
\hline Total Small Lycopsids & 4.0 & 3.2 & 8.8 & 19.2 & 4.0 & 9.6 & 7.6 \\
\hline Punctatisporites minutus & 24.4 & 22.0 & 18.0 & 15.2 & 16.4 & 28.4 & 12.8 \\
\hline Punctatosporites minutus & 2.0 & 4.4 & 2.8 & 4.0 & 3.2 & 2.4 & 4.8 \\
\hline P. rotundus & 8.0 & 1.2 & 0.4 & 0.4 & 3.2 & 2.4 & 3.2 \\
\hline Laevigatosporites globosus & 8.8 & 10.4 & 16.4 & 7.2 & 2.8 & 3.6 & 5.2 \\
\hline L. minimus & 6.0 & 6.4 & 1.2 & 1.2 & 1.2 & 2.8 & 1.2 \\
\hline L. ovalis & & & & 0.4 & & & \\
\hline Torispora securis & 0.8 & 10.8 & 5.2 & 2.8 & 0.8 & 0.4 & \\
\hline Thymospora obscura & $x$ & & 1.6 & 2.8 & & 0.4 & 0.4 \\
\hline T. pseudothiessenii & 7.2 & & 2.0 & 2.0 & 0.8 & & \\
\hline Cyclogranisporites minutus & & 0.4 & & & & & 0.4 \\
\hline C. orbicularis & & 0.4 & 2.0 & 0.4 & & 0.4 & \\
\hline C. multigranus & & $\mathrm{X}$ & $x$ & & & 2.0 & $x$ \\
\hline C. aureus & & 0.4 & & & & 0.8 & \\
\hline Total Tree Ferns & 57.2 & 56.4 & 49.6 & 36.4 & 28.4 & 43.6 & 28.0 \\
\hline Granulatisporites piroformis & 0.8 & 0.8 & 0.4 & & 0.8 & 0.4 & \\
\hline G. granulatus & $x$ & & & 0.4 & 0.4 & 0.4 & 0.8 \\
\hline G. parvus & 1.6 & 2.4 & 1.6 & & 1.6 & 2.4 & 0.8 \\
\hline G. adnatoides & 0.8 & & & & & 0.8 & \\
\hline G. verrucosus & 1.6 & & $x$ & $x$ & & 1.2 & $x$ \\
\hline G. minutus & 0.8 & & & & $x$ & 0.4 & \\
\hline Lophotriletes microsaetosus & $x$ & 1.2 & & & 0.4 & 2.0 & \\
\hline L. commissuralis & 2.4 & 0.8 & 0.4 & 0.4 & 4.0 & 3.6 & 1.2 \\
\hline \multicolumn{8}{|l|}{ L. mosaicus } \\
\hline L. gibbosus & & & & & & & 0.4 \\
\hline L. granoornatus & $x$ & & & & $\mathrm{X}$ & $\mathrm{X}$ & \\
\hline L. insignitus & & & $x$ & & $x$ & $x$ & \\
\hline L. pseudaculeatus & & & & & & $x$ & $x$ \\
\hline Deltoidospora subadnatoides & 4.8 & 2.4 & 1.6 & 0.4 & 2.8 & 4.4 & \\
\hline D. adnatus & & & & & 0.8 & & \\
\hline D. sphaerotriangulus & & 0.4 & & & & $x$ & $x$ \\
\hline D. priddyi & 0.4 & $x$ & & & & $x$ & $x$ \\
\hline D. levis & $x$ & 0.4 & 0.8 & & & 0.4 & 0.4 \\
\hline D. inflatus & & & $x$ & & $x$ & $x$ & \\
\hline Acanthotriletes aculeolatus & 0.4 & 0.4 & 0.4 & & 2.0 & 0.4 & \\
\hline \multicolumn{8}{|l|}{ A. dimorphus } \\
\hline A. triquetrus & 0.8 & 0.4 & & & & & 0.4 \\
\hline
\end{tabular}

Thymospora obscura and Thymospora pseudothiessenii, as Thymospora is regarded as index taxon for Asturian strata.

Small-fern spores are diverse and abundant, ranging in abundance from 2.8 to $18.0 \%$. Calamitalean spores, represented by Calamospora, Laevigatosporites minor, Laevigatosporites vulgaris, and Reticulatisporites, range from 4.8 to $15.6 \%$ of a given sample.

Seed plants are represented by a variety of pollen. Two types of seed-fern pollen, Schopfipollenites ellipsoides and Vesicaspora wilsonii are present, but only in two samples, one from a presumed wetland assemblage and one from a dryland assemblage (both from Comet Coal and Clay, Duke's Pit). Cordaitalean pollen, represented by Florinites, ranges in abundance from 2.0 to $16.8 \%$ in the samples. 


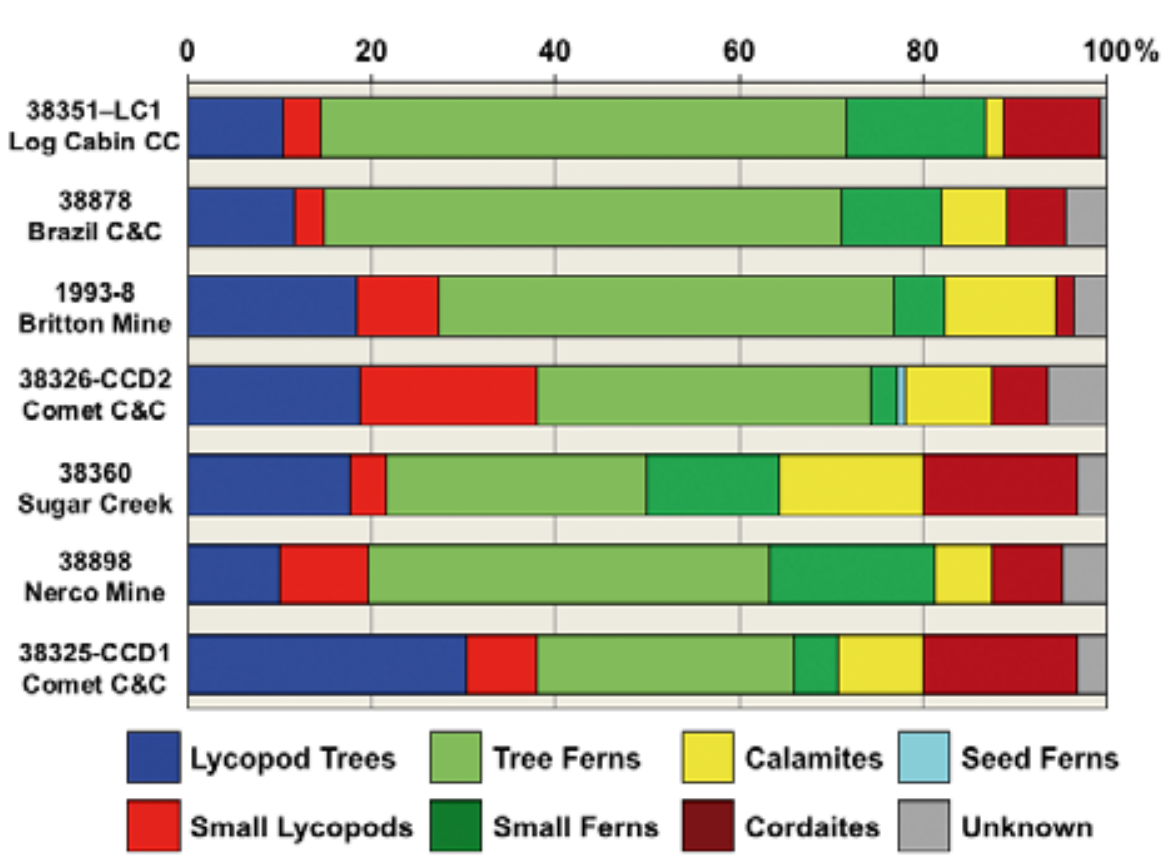

Figure 17. Palynomorph major-group composition of shale/siltstone macerations from inferred seasonally dry sample sites below Minshall-Buffaloville coal bed (USNM localities 38353, 38878, 43877 [19938], 38326, 38360, 38898) and, for comparison, one inferred wetland site from shale immediately above Minshall coal bed (38325).
Sparse conifer pollen, Potonieisporites (Illinites) elegans, was identified in two samples, one a presumed dryland deposit and the other a wetland deposit.

\section{DISCUSSION}

\subsection{Why are these floras preserved?}

The preservation of ostensibly "dryland" floras, those typical of landscapes that experienced significant seasonality in moisture availability, is uncommon. The reasons for this are spelled out in a number of papers on plant taphonomy (e.g., DiMichele \& Gastaldo, 2008; Gastaldo \& Demko, 2011; Looy et al., 2014a). The major obstacle to preservation is the need to remove the organic matter from the effects of oxygenic biotic and abiotic destruction. Thus, organic matter must be rapidly buried in a setting that removes it from a fluctuating water table in order to permit "short-term" preservation on the order of 10s to 1000s of years. Such burial can occur in numerous environments, but usually involves groundwatersupported, wetter portions of the landscape, even if that landscape is seasonally dry overall. If accumulation occurs in basinal areas, either coastal or intermontane, the plantbearing deposits may avoid exposure or oxidation for long enough to be engulfed by a rising water table, thus surviving into the "intermediate term" (10s of thousands of years). Such high water tables can result from shifts to a humid or perhumid climate characterized by yearround high precipitation, thus raising water tables to near the surface, or by a rising sea level on coastal plains. Survival over intermediate time frames provides such deposits the opportunity to be deeply buried by subsidence or tectonism, if they are located in depositional basins.

The greatest likelihood for the survival of organic matter in terrestrial deposits therefore is based on the combination of optimal conditions: (1) rapid burial below the vadose zone, (2) a setting where the climate and/or sealevel rise can raise the water table to near the soil surface for thousands of years, and (3) accumulation in a basinal setting, where erosion is minimized and subsidence is sufficient for deep burial.

During the Middle Pennsylvanian, the Illinois Basin was located in a paralic setting. In addition, the craton (coastal plain) was very flat and very broad (Watney et al., 1989; Greb et al., 2003), such that rising sea level could rapidly cover large areas. Furthermore, the Middle Pennsylvanian was a time of well-developed glacialinterglacial cycles, driven by fluctuations in SouthernHemisphere grounded ice volume (Fielding et al., 2008; Heckel, 2008; Peyser \& Poulsen, 2008), perhaps under the deeper control of orbital parameters (van den Belt et al., 2015). In such a setting, it may be possible to constrain the survival of strata containing a dryland flora to a relatively narrow portion of a glacial-interglacial cycle. The most probable interval is during the transition from strongly seasonally dry conditions to humid-toperhumid conditions, thereby capturing the seasonally dry flora in its final, basinal manifestations. Importantly, water tables would have begun to rise across the interior 
cratonic landscape during this time, providing the initial "short-term" conditions necessary for the preservation of organic-matter. In addition, as some recent models posit (e.g., Cecil et al., 2003; Peyser \& Poulsen, 2008; Eros et al., 2012; Cecil, 2013; Cecil et al., 2014; DiMichele, 2014; Bashforth et al., 2016b), the transition from seasonally dry, subhumid climates to humid/perhumid climates in central Pangea occurred during glacial maximum. Under this framework, the likelihood of short-term preservation would be enhanced, initially by increasing the area of the landscape with high water tables, and ultimately by the raising of water tables to the surface as rainfall became nearly continuous and high year-round. Such a sequence of climatic change is indicated by the juxtaposition of polygenetic soils that point to well-drained, seasonally dry conditions immediately below and transitioning to a coal, when conditions were favorable to peat formation (Rosenau et al., 2013a, b). "Intermediate-term" preservation also is made possible under this setting, as peat formation at low stand was terminated by sea-level rise as the craton flooded during the beginning of ice melting as glacial maximum transitioned to interglacial conditions. The short- and intermediate-term conditions, when combined with the basinal setting itself, permitted sufficient burial time for tectonic activity to remove the deposits from the zone of active, long-term erosion.

There is no indication of unusual tectonic activity in the Illinois Basin during the interval examined in this paper, such that burial might be considered a taphonomic accident. Floras from seasonally dry environments are preserved at other times and places in the Pangean tropics, and awareness of and focus on these dryland floras has increased in recent years.

\subsection{Macroflora and ecological implications}

The floras examined in this paper represent a type of assemblage that has been described by a variety of terms, most commonly "upland", but also such descriptors as "extrabasinal", introduced by Pfefferkorn (1980) to escape the implication that soil moisture limitations must result from drainage effects. However, the floras are clearly from within a basin, and moreover are from a landscape that probably was flat as a tabletop for thousands of kilometers in all directions from the site of deposition, and thus a long distance from any "uplands" (Bashforth et al., 2016b). Long-distance transport is clearly out of the question, given the quality of preservation of most specimens, the presence of intraformational conglomerate horizons, the small scale of the deposits themselves - indicative of limited amounts of water within the drainage areas - and the recurring depositional and compositional attributes of the deposits, spread across such a large area. Perhaps one of the best ways to look at these specimens is as "non- coal-measure" floras, as designated by Wagner (2004), with the implication of climatic controls on their distribution in time and space.

Evidence of the existence of basinal dryland floras during the Pennsylvanian is clear from deposits in western Pangea, where laterally persistent coal beds are exceedingly rare. The near absence of coal in these western areas suggests persistently seasonal subhumid to semi-arid climates (e.g., Lyons \& Darrah, 1989; Lucas et al., 2013) during all phases of the same glacial-interglacial cycles in which beds of peat (coal) formed in the central Pangean equatorial basins during the wettest phases of these same cycles. However, there also is evidence that dryland vegetation, existing under subhumid to semi-arid climates, populated the central Pangean coal basins themselves for extended periods, during which wetland floras may have retreated into refugia (Falcon-Lang \& DiMichele, 2010; Looy et al., 2014b). Some of these basinal dryland macrofloras may indeed capture elevational variations along basin margins, such as those described from deposits across west-central Pangea (Leary \& Pfefferkorn, 1977; Wagner, 2001; Falcon-Lang \& Bashforth, 2004; Gastaldo \& Degges, 2007; Bashforth et al., 2014) and from the Variscan Mountains of central Pangea (Broutin et al., 1990; Opluštil \& Cleal, 2007; Libertín et al., 2009). However, others, mainly from west-central Pangea, where high elevational areas were located great distances from coalbearing basins, are clearly from within basinal settings (Cridland \& Morris, 1963; Falcon-Lang, 2003; FalconLang et al., 2009; Plotnick et al., 2009), where their composition almost certainly reflects climatic conditions at the site of growth and burial.

The cordaitalean floras described here may find their closest modern analogue in tropical, seasonally dry forests (reviewed by Eamus, 1999). In today's world, where most vegetation is characterized by angiosperm dominance, such forests comprise different proportions of evergreen and deciduous trees (depending on geographical setting), and vary from forests and woodlands, with closed tree canopies, to open savannas, with scattered trees and largely grass ground cover. In the late Paleozoic tropics, however, there is little evidence for seasonal deciduousness of any major type of tree, and there are no grasses or even good grass analogues. Consequently, it is probable that the plant fossils described herein were drawn from communities of evergreen vegetation. Evergreen plants in tropical dry forests, particularly if temperature variations are small annually, must be drought tolerant, meaning that they must have access to a water source during the dry season, often combined with coriaceous leaves that are resistant to passive evaporative and even transpirative water loss. Most such plants, particularly if they are large and woody, as surmised for the cordaitaleans in dryland or upland settings (Falcon-Lang \& Bashforth, 2005; Gastaldo \& Degges, 2007; Davies \& Gibling, 2013; Bashforth et al., 
2014), rely on deeply penetrating root systems. In contrast, deciduous trees, which "avoid" drought by dropping their leaves during the dry season, tend to have shallower, platelike rooting systems. Although we do not know if the parent plants that produced the Cordaites, Lesleya, and Taeniopteris leaves documented herein were of tree habit, of large size, or deeply rooted, none show any evidence of deciduousness - leaves are large, of robust construction, and, in Lesleya and Taeniopteris, may have had woody petioles, all indicative of leaves with long, multi-season life spans. The habit of Sphenopteridium sp. is uncertain, although specimens from western Pangea (New Mexico, Kinney Quarry), suggest a small, corm-like stem from which upright compound leaves, up to a meter in length, emerged, thus also probably having an evergreen habit.

The leaf architectures of the dominant dryland plants in these Pennsylvanian assemblages all qualify as "slow" in terms of the modern, so-called "leaf economics spectrum" (Wright et al., 2004). As noted above, the leaves appear to have been large, but of coriaceous, robust construction, with heavy investments in sclerenchymatous tissues, and in woody tissues that extend into petiolar bases in Lesleya and Taeniopteris. These traits suggest an evergreen habit and leaf retention for multiple seasons. In extant plants, such features correlate with slower metabolic rates and other traits, such as physical and chemical resistance to attack by animals (investment in protective mechanisms, given the long retention times of the foliage) (Royer et al., 2007). This noted, it also has been observed that Pennsylvanian tropical wetland plants display many of these characteristics, in addition to large leaf sizes (compound frond-like leaves, often many meters long), implying relatively slow physiologies compared to modern tropical rainforest trees (Stull et al., 2012; Raymond et al., 2014). As a consequence of the widespread nature of this constructional aspect, Stull et al. (2012) suggested, among other possible explanations, that such features may simply reflect "phylogenetic constraint" - in other words, rather than being proximate adaptations, robust leaf construction and slow physiology may reflect the ancestral conditions in these lineages, deciduousness and fast physiologies not yet having evolved along the same lines as found in angiosperms.

How dry were the habitats occupied by these cordaitaleandominated floras? As discussed by Šimůnek (2008) and Bashforth et al. (2014), cordaitaleans likely favored more consistently wet environments than conifers. The climatic conditions under which the large, drought-tolerant trees flourished probably were on the more subhumid than the semi-arid part of the climate spectrum. As discussed above, this may reflect the stratigraphic position of these floras at the transition from seasonally dry to more continuously wet conditions during glacial maximum.

A final noteworthy aspect of these assemblages is their low biodiversity. This is not novel, as such low biodiversity characterizes both wetland and dryland biomes in the
Pennsylvanian and Permian (Bashforth et al., 2010, 2011, 2014; DiMichele, 2014). Species numbers in the 1000 range, such as noted by Wagner (2004), encompass the entire Pennsylvanian and all of its Euramerican expanse, and even 1000 species pales in comparison to plant species diversity in the modern tropics. In contrast, focused studies on large collections of wetland plants from single time horizons, sampling anything from a local area to a drainage basin (e.g., Pfefferkorn, 1979; King et al., 2011; Moore et al., 2014), reveal species diversities in low 100s at most. And, as evident from this study, the dryland biome had a significantly lower diversity, even though diversity would probably double with increased sample size, given the small number of rare macrofossil taxa encountered and the higher diversity of the palynoflora, including many wetland plants. It seems that the late Paleozoic, at any given time and place, simply had significantly lower biodiversity than modern areas with similar climate, edaphics, and exposure/ aspect. This fact has profound implications for the role of biodiversity in creating stable ecosystems, with those of the late Paleozoic apparently being quite stable for relatively long time periods.

\subsection{Macroflora-palynoflora contrast}

As noted by other authors, focusing both on late Paleozoic and younger floras (e.g., Wagner, 1984; Mander et al., 2010; Tabor et al., 2013b; Looy et al., 2014b; Bashforth et al., 2016b), there are consistent conflicts between the composition of palynofloras and macrofloras drawn from seasonally dry environments. However, such conflicts also may result in comparisons of macrofloras and palynofloras from wetland settings (e.g., Willard, 1993; Opluštil et al., 2009b). Most troubling is the fact that wetland species frequently dominate palynological assemblages drawn from the same rocks that contain macrofloral assemblages dominated by dryland elements. The explanation for such incongruences may be straightforward. And although the most likely explanations might appear to be nonoverlapping, in fact both may have been operative.

The simplest explanation is reworking of the wetland palynomorphs into the sediments deposited during the period of seasonal dryness. Factors in favor of this hypothesis mainly reflect the fact that the dry landscape drainage systems seem to have cannibalized sediments from within relatively small areas of erosion and to have been of limited areal extent, capturing sediment locally rather than from distant sources - i.e., the sediments are primarily "intraformational". Thus, recently deposited, surficial sediments, eroded from strata deposited during the preceding glacial cycle, would have been enriched in wetland plant spores and pollen from that earlier time, which had not been subject to the diagenetic effects of pressure and temperature accompanying deep burial. Given the prolific spore output 
of many of these wetland plants, particularly tree ferns and lycopsids, such slightly older rocks may have yielded a very large load of such palynomorphs compared to those being produced by the living, dryland flora.

Alternatively, pockets of wetland plants may have survived in seasonally dry environments wherever there was a sufficiently high water table to support them. Such habitats might have included stream and lake margins, or even low areas on landscapes that were subhumid and had dry seasons, where evapotranspiration exceeded rainfall, if only for a few months per year. As Raymond \& Costanza (2007) and DiMichele (2014) noted, the vast majority of Pennsylvanian plant evolutionary lineages were wind pollinated and/or had wind dispersed propagules. This reproductive mode would account for the long temporal conservatism of most species, because gene flow could continue during periods when wetland plants were forced into refugia. In contrast, it appears that plants tolerant of soil-moisture deficits, also overwhelmingly wind pollinated and dispersed, were parts of biomes that maintained large areal coverage at all times, through glacial-interglacial cycles, in the western Pangean tropics, and probably as isolated pockets within the Variscan Mountains (Broutin et al., 1990; Opluštil \& Cleal, 2007; Hawkins et al., 2013). Modern seasonally dry landscapes usually have numerous, disconnected habitats with high water tables, even swamps. In contrast, areas under widespread humid to perhumid conditions (where rainfall exceeds evapotranspiration for $>10$ months per year, sensu Cecil, 2003) rarely include habitats with seasonally dry conditions, or with soil drainage so severe that plants would perceive them as "dry". Thus, there would be few areas within a widespread humid climate region that would permit the survival of plants adapted to periodic, relatively long moisture deficits. An exception may be at high elevations, where drainage effects may come into play, although under perhumid conditions, such elevational effects may be more reflective of temperature than moisture availability.

Somewhat more difficult to explain is the occurrence of pollen from dryland plants in what otherwise appears to be a wetland-dominated flora. The occurrence of the coniferous pollen Potonieisporites (Illinites) elegans in one of the wetland comparative samples either reflects proximity of the source plants to the site of deposition, reflecting an unexpected degree of landscape heterogeneity, or reworking of the pollen from older strata. The only other examples of this pattern known to us were reported by Tabor et al. (2013b), from a broad survey of latest Late Pennsylvanian floras from northcentral Texas, and by Looy \& Hotton (2014) from a single, microstratigraphically analyzed site from the same stratigraphic interval. Both papers offer several alternative explanations for these occurrences, but Looy \& Hotton (2014) preferred landscape heterogeneity. During the Pennsylvanian-Permian transition in north-central Texas
(Tabor et al., 2013a), wetlands progressively diminished while environments with moisture deficits expanded. Looy \& Hotton (2014) described this as "a fragmenting and increasingly arid environment", a pattern corroborated by proxy paleosol and geochemical indicators (Tabor et al., 2013a). Perhaps, on a small scale, the development of landscape heterogeneity under increasingly seasonal climates may have promoted the dispersal of conifers and other drought-tolerant plants into the basinal areas, as the remnants of wetland habitats progressively shrunk. A similar circumstance may explain the presence of this kind of pollen in a roof-shale assemblage in the wetland sample.

\subsection{Biostratigraphy}

Regardless of interpreted wetland vs. dryland origin, based on macroflora and physical sedimentology and stratigraphy, the palynological samples analyzed in this study are compositionally similar. All assemblages contain elements of both the Radiizonates difformis (RD), and overlying Cadiospora magna - Mooreisporites inusitatus (MI) spore assemblage zones, constructed by Peppers $(1985,1996)$ for Illinois Basin coals. The RD assemblage zone is indicative of a late Atokan (late Bolsovian) age, whereas the MI assemblage zone is indicative of an early Desmoinesian (latest Bolsovian to middle Asturian) age. The results indicate that the range zones of the index taxa used to define the miospore assemblage zones are slightly different for clastic lithologies. As a consequence, further refinement of spore and pollen ranges, through the palynological analysis of clastic strata, is needed to clarify the Atokan/Desmoinesian and Bolsovian/Asturian boundaries in the Illinois Basin, as has been attempted using macrofloral assemblages (Bashforth \& Nelson, 2015; Bashforth et al., 2016a).

Peppers (1996, p. 53-56) summarized the utility of palynology as a biostratigraphic tool to discern the Bolsovian/Asturian boundary, which he considered coincident with the Atokan/Desmoinesian boundary, especially as it applies to Illinois Basin coals. The appearance of Neuropteris ovata has been used to define the base of Asturian age strata worldwide (see Bashforth \& Nelson, 2015 for a synthesis). Smith \& Butterworth (1967) considered the first occurrence of Thymospora to mark the Bolsovian - Asturian boundary in Great Britain. However, Grebe (1972), Loboziak (1974), and van de Laar \& Fermont (1990) showed that Thymospora occurs slightly before the first appearance of Neuropteris ovata in northern France, the Ruhr basin, and The Netherlands, respectively. In their western European summaries, Clayton et al. (1977) and Owens et al. (1978) considered Thymospora to originate in the latest Bolsovian. Other useful palynomorphs for determining the Bolsovian - Asturian boundary include Cadiospora magna and Mooreisporites inusitatus, which 
first appear in lower Asturian strata. Murospora kosankei also appears at about this level (perhaps slightly earlier?). The termination of Savitrisporites nux just below, and Dictyotriletes bireticulatus just above, the boundary also are useful biostratigraphic indicators.

\subsection{Stratigraphic position and implications for environmental change}

The time interval considered herein, the AtokanDesmoinesian regional stage boundary in the USA, is broadly equivalent to, albeit not coincident with, the Bolsovian-Asturian terrestrial stage boundary in Western Europe (Peppers, 1996; Blake et al., 2002; Bashforth $\&$ Nelson, 2015). This time period encompasses a significant environmental change across the Euramerican portion of equatorial Pangea, inferred from a number of environmental proxies. These include the change from peats interpreted as ombrotrophic/domed, predominant in the Atokan/Duckmantian-Bolsovian (Eble \& Grady, 1990; Grady et al., 1992; Calder, 1993; Jasper et al., 2010a, b), to mostly planar peat geometries in the Desmoinesian/ Asturian (Cecil et al., 1985; Pierce et al., 1991, 1993; Hower et al., 1996; Kosanke \& Cecil, 1996; Eble et al., 1999; Opluštil et al., 2007). The changes are reflected in the petrographic character of the coals, which show distinct distributional patterns of dull vs. bright coal lithotypes in coals derived from suspected domed parent peats versus the absence of such patterns in suspected planar peats. In addition, in many of the studies cited above, such changes in coal character in coals interpreted as originating from domed peats correlate with distinct vertical changes in the palynofloras. In contrast, coals interpreted as planar in origin show little to no shift in composition in vertical profiles, except at the top of the coal, probably related to siliciclastic influx and hydrological changes that resulted from drowning of the swamp. These fluctuations in the physical and biological character of coals point to a change from perhumid to humid conditions during the wettest parts of glacial-interglacial cycles as the Pennsylvanian progressed. Geochemical differences also are noted in coals across the Atokan-Desmoinesian boundary, namely an increase in ash content and changes in the abundance of trace elements, particularly a significant increase in sulfur (Neuzil et al., 2005). Non-marine carbonates also become more abundant, both in distinct beds and distributed in coals and associated terrestrial siliclastic rocks (Cecil, 1990; Cecil et al., 1993). Likewise, coal balls become more common and widespread in Desmoinesian coals (Phillips et al., 1985). Such changes point to lower water flux on the landscape. Other changes across the Bolsovian-Asturian boundary are evident in the character of fluvial sandstones (Bertier et al., 2008), including significant differences in porosity and degree of weathering of constituent grains.
Similar changes have been observed in sandstones from the Illinois Basin study area. The character of paleosols also differs across the boundary, with an increase in vertic features and carbonate content, indicative of increased moisture seasonality (Rosenau et al., 2013a, b). Many of these physical changes have been observed by the authors in strata across the Brazil-Staunton contact, including a large increase in pyritic sulfur in the coals and associated siliciclastic rocks, the appearance of coal balls, and a shift from Ultisols to Vertisols in underclays beneath coals. These environmental changes are independent of any compositional shifts in associated plant-fossil assemblages.

Several mechanisms may be responsible for the changes across the boundary interval, given how variably they are expressed across the Euramerican part of central Pangea. However, an underlying theme appears to be consistent in all of the examples, regardless of whether they are recorded from Europe or North America, namely a general trend toward drier, more seasonal rainfall conditions (e.g., Cecil et al., 1985, 1993; Kosanke \& Cecil, 1996; Neuzil et al., 2005; Bertier et al., 2008; Rosenau et al., 2013 a, b; van Hoof et al., 2013). A long-scale shift in climatic conditions has the potential for global effects, even if the changes are manifest differently at regional and local scales. On the other hand, tectonics, specifically orogenesis in Central Europe, would not have produced such synchronous and widespread effects, as demonstrated by the significant differences in patterns within, and north and south of the Variscan Mountains (Opluštil et al., 2007; Cleal et al., 2009; Bashforth et al., 2010, 2011; Wagner \& ÁlvarezVázquez, 2010; van Hoof et al., 2013). Nonetheless, tectonics may have affected patterns of air circulation that drove regional climate changes (van Hoof et al., 2013), and likely played a major role in creating environmental heterogeneity across the boundary interval.

There is evidence that major vegetational and ecological shifts occurred in tandem with the aforementioned environmental changes across the broadly coeval AtokanDesmoinesian and Bolsovian-Asturian boundaries. In the western European basins analyzed by Opluštil \& Cleal (2007), the diversity of arborescent lycopsids declined while marattialean tree ferns increased, detectable in both the macrofossil and palynological records of wetland floras. In most of the European basins analyzed by these authors, the Bolsovian-Asturian boundary is marked by a significant depositional hiatus. On the northern flanks of the Variscan Mountains, there is a dramatic floristic shift from wetlandto dryland-dominated floras, reflecting climatic changes that probably were undergirded by tectonic uplift (van Hoof et al., 2013). In this instance, the floristic changes were dramatic enough to have sparked controversies in age estimation and correlation, some authors inferring a huge temporal gap between the Bolsovian and Permian (summarized by van Hoof et al., 2013). Floristic changes involving the appearance of dryland vegetation were more 
prominent in Atlantic Canada (e.g., Falcon-Lang, 2003), an area that was more biogeographically linked to Europe than the Appalachians and more westerly portions of Pangea. Pendleton \& Wellman (2013) documented a spatially complex vegetational and ecological turnover based on the record of lycopsid megaspores and pteridosperm pollen, in the context of environmental conditions. Vegetational changes in the west-central Pangean cratonic area of North America are more subtle and less spatially variable than those of northern Europe, Britain or Atlantic Canada, and involve the initial phases of rising tree fern abundance in wetlands (Pfefferkorn \& Thomson, 1982; Phillips et $a l ., 1985)$ and the sporadic appearance of conifers in the poorly known dryland record (Falcon-Lang et al., 2009; Plotnick et al., 2009). Nonetheless, it is during the Atokan-Desmoinesian transition that tree ferns begin their quantitative rise in biomass and that cordaitaleans undergo a notable change in species composition and reduction in abundance, culminating in their ecological insignificance in wetlands by the middle Desmoinesian (early Cantabrian).

Examinations of floristic change viewed from a biostratigraphic perspective, thus largely based on presenceabsence data, do not reveal a major taxonomic turnover across the Atokan-Desmoinesian boundary in the U.S. (e.g., Peppers, 1996; Blake et al., 2002; Eble et al., 2009) or Bolsovian-Asturian boundary in Europe (e.g., Cleal et al., 2012), particularly when comparing isotaphonomic assemblages. For example, Cleal et al. (2012, p. 142) state "Overall, the evidence suggests that, as in the other areas investigated in this study, there is in fact no major change in the vegetation at the Bolsovian-Asturian boundary." However, presence-absence and quantitative ecological examinations may present different but complementary perspectives. Palynologically based analyses may bring these perspectives together to some degree, because assessments of temporal taxonomic turnover (and biostratigraphy) generally take relative abundances into account, in part reflecting the quantification involved in data generation. Quantification techniques are becoming increasingly common in the analysis of adpressed plantfossil assemblages, and have been an integral component of vegetational analyses of coal balls for over 30 years. An integrated examination of the data, therefore, suggests that the Atokan-Desmoinesian transition, a time of reasonably well-documented environmental change across the equatorial regions of central and western Pangea, involved a change in the distribution of biomass dominance, superimposed on a background of taxonomic turnover that was not markedly greater than noted at other biostratigraphically defined boundaries. Some distinctive species disappeared and others appeared, permitting a boundary to be recognized. However, the distribution of dominance changed considerably in wetland assemblages, over a relatively short geological interval, but one that involved a number of glacial-interglacial cycles. As a result, previously minor groups expanded and previously abundant groups contracted, leading to distinctive differences in the architectural composition of the vegetation. The dryland vegetation documented herein can be considered a herald of these changes in wetland associations, with which it alternated in the tropical lowlands of Pangea.

\section{ACKNOWLEDGEMENTS}

This paper is dedicated to Robert H. Wagner, a friend and a model paleobotanist, whose knowledge, capacity for broad thinking, meticulous technique, and scrupulous taxonomic practice (and someone who could offer this same dedication fluently in 5 or more languages) we can only aspire to emulate. WD thanks AMAX Coal Company, David L. Dilcher at Indiana University, and the National Science Foundation for initial support of the fieldwork, from 1980 through 1987, on which much of this study is based. ARB acknowledges support from an Arthur James Boucot Research Grant from the Paleontological Society. We thank Phil Ames of Terre Haute, Indiana for his contributions to our stratigraphic understanding of the Brazil and Staunton formations in Indiana. Philip H. Heckel, University of Iowa, kindly shared his findings and interpretations of the stratigraphy of the study interval. We extend our thanks also to Carmen Álvarez-Vázquez, Edward S. Belt and Stanislav Opluštil for their careful reading and constructive comments on an earlier version of this paper.

\section{REFERENCES}

Amerom, H.W.J. van 1975. Die eusphenopteridischen Pteridophyllen aus der Sammlung des Geologischen Bureaus in Heerlen, unter besonderer Berücksichtigung ihrer Stratigraphie bezüglich des südlimburger Kohlenreviers. Mededelingen Rijks Geologische Dienst, Serie III-C-1, 7, 1-101.

Ash, S. \& Tidwell, W.D. 1986. Arnoldia kuesii, a new juvenile fernlike plant from the Lower Permian of New Mexico. Botanical Gazette, 147, 236-242.

Barthel, M. 2004. Die Rotliegendflora des Thüringer Waldes. Teil 2: Calamiten und Lepidophyten. Veröffentlichungen Naturhistorisches Museum Schleusingen, 19, 19-48.

Barthel, M. 2006. Die Rotliegendflora des Thüringer Waldes. Teil 4: Farnsamer und Farnlaub unbekannter taxonomischer Stellung. Veröffentlichungen Naturhistorisches Museum Schleusingen, 21, 33-72.

Bashforth, A.R. \& Nelson, W.J. 2015. A Middle Pennsylvanian macrofloral assemblage from below the Rock Island (No. 1) 
Coal Member, Illinois: Resolving the BolsovianAsturian boundary in the Illinois Basin. Review of Palaeobotany and Palynology, 222, 67-83; doi:10.1016/j. revpalbo.2015.07.003.

Bashforth, A.R., Falcon-Lang, H.J. \& Gibling, M.R. 2010. Vegetation heterogeneity on a Late Pennsylvanian braidedriver plain draining the Variscan Mountains, La Magdalena Coalfield, northwestern Spain. Palaeogeography, Palaeoclimatology, Palaeoecology, 292, 367-390; doi:10.1016/j.palaeo.2010.03.037.

Bashforth, A.R., DiMichele, W.A., Eble, C.F. \& Nelson, W.J. 2016a. A Middle Pennsylvanian macrofloral assemblage from wetland deposits in Indiana (Illinois Basin): A taxonomic contribution with biostratigraphic, paleobiogeographic, and paleoecologic implications. Journal of Paleontology, 80.

Bashforth, A.R., DiMichele, W.A., Eble, C.F. \& Nelson, W.J. 2016b. Dryland vegetation from the Middle Pennsylvanian of Indiana (Illinois Basin): The dryland biome in glacioeustatic, paleobiogeographic and paleoecologic context. Journal of Paleontology, 80.

Bashforth, A.R., Cleal, C.J., Gibling, M.R., Falcon-Lang, H.J. \& Miller, R.F. 2014. Paleoecology of Early Pennsylvanian vegetation on a seasonally dry tropical landscape (Tynemouth Creek Formation, New Brunswick, Canada). Review of Palaeobotany and Palynology, 200, 229-263; doi:10.1016/j.revpalbo.2013.09.006.

Bashforth, A.R., Drábková, J., Opluštil, S., Gibling, M.R. \& Falcon-Lang, H.J. 2011. Landscape gradients and patchiness in riparian vegetation on a Middle Pennsylvanian braided-river plain prone to flood disturbance (Nýřany Member, Central and Western Bohemian Basin, Czech Republic). Review of Palaeobotany and Palynology, 163, 153-189; doi:10.1016/j.revpalbo.2010.10.001.

Bek, J. \& Pšenička, J. 2001. Senftenbergia plumosa (Artis) emend. and its spores from the Carboniferous of the Kladno and Pilsen basins, Bohemian Massif, and some related and synonymous taxa. Review of Palaeobotany and Palynology, 116, 213-232; doi:10.1016/S00346667(01)00091-4.

Belt, F.J.G. van den, Hoof, T.B. van \& Pagnier, H.J.M. 2015. Revealing the hidden Milankovitch record from Pennsylvanian cyclothem successions and implications regarding late Paleozoic chronology and terrestrial-carbon (coal) storage. Geosphere, 11, 1062-1076; doi:10.1130/ GES01177.1.

Bertier, P., Swennen, R., Lagrou, D., Laenen, B. \& Kemps, R. 2008. Palaeo-climate controlled diagenesis of the Westphalian C \& D fluvial sandstones in the Campine Basin (north-east Belgium). Sedimentology, 55, 13751417; doi:10.1111/j.1365-3091.2008.00950.x.

Blake, B.M., Cross, A.T., Eble, C.F., Gillespie, W.H. \& Pfefferkorn, H.W. 2002. Selected plant megafossils from the Carboniferous of the Appalachian region, United States: geographic and stratigraphic distribution. In: Carboniferous and Permian of the World (eds. Hills, L.V., Henderson, C.W. \& Bamber, E.W.). Canadian Society of Petroleum Geologists Memoir, 19, 259-335.
Boersma, M. 1972. The heterogeneity of the form genus Mariopteris Zeiller. A comparative morphological study with special reference to the frond composition of WestEuropean species. Elinkwijk, Utrecht, 1-172.

Brousmiche, C. 1983. Les Fougères sphénoptéridiennes du Bassin Houiller Sarro-Lorrain (Systématique, stratigraphie). Société Géologique du Nord, Publication, 10, 1-480.

Broutin, J., Doubinger, J., Farjanel, G., Freytet, F., Kerp, H., Langiaux, J., Lebreton, M.L., Sebban, S. \& Satta, S. 1990. Le renouvellement des flores au passage Carbonifère Permien: approches stratigraphique, biologique, sédimentologique. Comptes Rendus Académie des Sciences, Paris, 311, 1563-1569.

Calder, J.H. 1993. The evolution of a ground-water-influenced (Westphalian B) peat-forming ecosystem in a piedmont setting: The No. 3 seam, Springhill coalfield, Cumberland Basin, Nova Scotia. Geological Society of America Special Papers, 286, 153-180; doi:10.1130/SPE286-p153.

Cecil, C.B. 1990. Paleoclimate controls on stratigraphic repetition of chemical and siliciclastic rocks. Geology, 18, 533-536; doi: 10.1130/0091-7613(1990) 018<0533:PCOSRO $>2.3 . \mathrm{CO} ; 2$.

Cecil, C.B. 2003. The concept of autocyclic and allocyclic controls on sedimentation and stratigraphy, emphasizing the climate variable. SEPM Special Publications, 77, 13-20.

Cecil, C.B. 2013. An overview and interpretation of autocyclic and allocyclic processes and the accumulation of strata during the Pennsylvanian-Permian transition in the central Appalachian Basin, USA. International Journal of Coal Geology, 119, 21-31; doi:10.1016/j.coal.2013.07.012.

Cecil, C.B., DiMichele, W.A. \& Elrick, S.D. 2014. Middle and Late Pennsylvanian cyclothems, American Midcontinent: Ice-age environmental changes and terrestrial biotic dynamics. Comptes Rendus Géoscience, 346, 159-168; doi : 10.1016/j.crte.2014.03.008.

Cecil, C.B., Dulong, F.T., Cobb, J.C. \& Supardi 1993. Allogenic and autogenic controls on sedimentation in the central Sumatra basin as an analogue for Pennsylvanian coal-bearing strata in the Appalachian basin. In: Modern and Ancient Coal-Forming Environments (eds. Cobb, J.C. \& Cecil, C.B.). Geological Society of America, Special Paper, 286, 3-22.

Cecil, C.B., Dulong, F.T., West, R.R., Stamm, R., Wardlaw, B.A. \& Edgar, N.T. 2003. Climate controls on the stratigraphy of a Middle Pennsylvanian cyclothem in North America. In: Climate controls on stratigraphy (eds. Cecil, C.B. \& Edgar, N.T.). SEPM Special Publications, 77, 151-182.

Cecil, C.B., Stanton, R.W., Neuzil, S.G., Dulong, F.T., Ruppert, L.F. \& Pierce, B.S. 1985. Paleoclimate controls on late Paleozoic sedimentation and peat formation in the central Appalachian Basin (U.S.A.). International Journal of Coal Geology, 5, 195-230; doi:10.1016/01665162(85)90014-X.

Clayton, G., Coquel, R., Doubinger, J., Gueinn, K.J., Loboziak, S., Owens, B. \& Streel, M. 1977. Carboniferous 
miospores of western Europe: illustations and zonation. Mededelingen Rijks Geologische Dienst, 29, 1-71.

Cleal, C.J. 2015. The generic taxonomy of Pennsylvanian age marattialean fern frond adpressions. Palaeontographica, Abt. B, 292, 1-21.

Cleal, C.J., Opluštil, S., Thomas, B.A. \& Tenchov, Y. (eds.) 2009. Late Moscovian terrestrial biotas and palaeoenvironments of Variscan Euramerica. Netherlands Journal of Geosciences - Geologie en Mijnbouw, 88, 181-278.

Cleal, C.J., Uhl, D., Cascales-Miñana, B., Thomas, B.A., Bashforth, A.R., King, S.C. \& Zodrow, E.L. 2012. Plant biodiversity changes in Carboniferous tropical wetlands. Earth-Science Reviews, 114, 124-155; doi:10.1016/j. earscirev.2012.05.004.

Costanza, S.H. 1985. Pennsylvanioxylon of Middle and Upper Pennsylvanian Coals from the Illinois Basin and its comparison with Mesoxylon. Palaeontographica, Abt. $B, 197,81-121$.

Cridland, A.A. 1964. Amyelon in American coal balls. Palaeontology, 7, 186-209.

Cridland, A.A. \& Morris, J.E. 1963. Taeniopteris, Walchia and Dichophyllum in the Pennsylvanian System of Kansas. University of Kansas Science Bulletin, 44, 71-85.

Darrah, W.C. 1939. The fossil flora of Iowa coal balls. I. Discovery and occurrence. Botanical Museum Leaflets, Harvard University, 7, 125-136.

Davies, N.S. \& Gibling, M.R. 2013. The sedimentary record of Carboniferous rivers: Continuing influence of land plant evolution on alluvial processes and Palaeozoic ecosystems. Earth-Science Reviews, 120, 40-79; doi:10.1016/j. earscirev.2013.02.004.

DiMichele, W.A. 2014. Wetland-dryland vegetational dynamics in the Pennsylvanian ice age tropics. International Journal of Plant Sciences, 175, 123-164; doi:10.1086/675235.

DiMichele, W.A. \& Falcon-Lang, H.J. 2012. Calamitalean "pith casts" reconsidered. Review of Palaeobotany and Palynology, 173, 1-14; doi:10.1016/j.revpalbo.2012.01.011.

DiMichele, W.A. \& Gastaldo, R.A. 2008. Plant paleoecology in deep time. Annals of the Missouri Botanical Garden, 95, 144-198.

DiMichele, W.A., Pfefferkorn, H.W. \& Gastaldo, R.A. 2001. Response of Late Carboniferous and Early Permian plant communities to climate change. Annual Review of Earth and Planetary Sciences, 29, 461-487.

DiMichele, W.A., Phillips, T.L. \& McBrinn, G.E. 1991. Quantitative analysis and paleoecology of the Secor coal and roof-shale floras (Middle Pennsylvanian, Oklahoma). Palaios, 6, 390-409; doi:10.2307/3514965.

DiMichele, W.A., Cecil, C.B., Montañez, I.P. \& Falcon-Lang, H.J. 2010. Cyclic changes in Pennsylvanian paleoclimate and effects on floristic dynamics in tropical Pangaea. International Journal of Coal Geology, 83, 329-344; doi:10.1016/j.coal.2010.01.007.

DiMichele, W.A., Tabor, N.J., Chaney, D.S. \& Nelson, W.J. 2006. From wetlands to wet spots: environmental tracking and the fate of Carboniferous elements in Early Permian tropical floras. Geological Society of America Special Papers, 399, 223-248.
DiMichele, W.A., Wagner, R.H., Bashforth, A.R. \& ÁlvarezVázquez, C. 2013. An update on the flora of the Kinney Quarry of central New Mexico (Upper Pennsylvanian), its preservational and environmental significance. In: The Carboniferous-Permian Transition in Central New Mexico (eds. Lucas, S.G., Nelson, W.J., DiMichele, W.A., Spielmann, J.A., Krainer, K., Barrick, J.E., Elrick, S. \& Voigt, S). New Mexico Museum of Natural History and Science Bulletin, 59, 289-325.

Dimitrova, T.K., Cleal, C.J., \& Thomas, B.A. 2011. Palynological evidence for Pennsylvanian extra-basinal vegetation in Atlantic Canada. Journal of the Geological Society, 168, 559-569; doi: 10.1002/gj.1179.

Eamus, D. 1999. Ecophysiological traits of deciduous and evergreen woody species in the seasonally dry tropics. Trends in Ecology \& Evolution, 14, 11-16; doi:10.1016/ S0169-5347(98)01532-8.

Eble, C.F. \& Grady, W.C. 1990. Paleoecological interpretation of a Middle Pennsylvanian coal bed in the central Appalachian basin, U.S.A. International Journal of Coal Geology, 16, 255-286; doi:10.1016/0166-5162(90)90054-3.

Eble, C.F., Blake, B.M., Gillespie, W.H. \& Pfefferkorn, H.W. 2009. Appalachian Basin floras. Kentucky Geological Survey, Special Publication, 5, 46-58.

Eble, C.F., Greb, S.F., Williams, D.A. \& Hower, J.C. 1999. Observations on the palynology, petrography and geochemistry of the Western Kentucky number 4 coal bed. International Journal of Coal Geology, 39, 121-139; doi:10.1016/S0166-5162(98)00042-1.

Eggert, D.A. \& Taylor, T.N. 1971. Telangiopsis gen. nov., an Upper Mississippian pollen organ from Arkansas. Botanical Gazette, 132, 30-37.

Eros, J.M., Montañez, I.P., Osleger, D.A., Davydov, V.I., Nemyrovska, T.I., Poletaev, V.I. \& Zhykalyak, M.V. 2012. Sequence stratigraphy and onlap history of the Donets Basin, Ukraine: Insight into Carboniferous icehouse dynamics. Palaeogeography, Palaeoclimatology, Palaeoecology, 313, 1-25; doi:10.1016/j.palaeo.2011.08.019.

Falcon-Lang, H.J. 1999. Fire ecology of a Late Carboniferous floodplain, Joggins, Nova Scotia. Journal of the Geological Society, 156, 137-148; doi: 10.1144/gsjgs.156.1.0137.

Falcon-Lang, H.J. 2000. Fire ecology of the Carboniferous tropical zone. Palaeogeography, Palaeoclimatology, Palaeoecology, 164, 339-355; doi:10.1016/S00310182(00)00193-0.

Falcon-Lang, H.J. 2003. Late Carbonferous tropical dryland vegetation in an alluvial-plain setting, Joggins, Nova Scotia, Canada. Palaios, 18, 197-211; doi:10.1669/08831351(2003)018<0197:LCTDVI >2.0.CO;2.

Falcon-Lang, H.J. 2015. A calamitalean forest preserved in growth position in the Pennsylvanian coal measures of South Wales: Implications for palaeoecology, ontogeny and taphonomy. Review of Palaeobotany and Palynology, 214, 51-67; doi:10.1016/j.revpalbo.2014.10.001.

Falcon-Lang, H.J. \& Bashforth, A.R. 2004. Pennsylvanian uplands were forested by giant cordaitalean trees. Geology, 32, 417-420; doi:10.1130/G20371.1. 
Falcon-Lang, H.J. \& Bashforth, A.R. 2005. Morphology, anatomy, and upland ecology of large cordaitalean trees from the Middle Pennsylvanian of Newfoundland. Review of Palaeobotany and Palynology, 135, 223-243; doi:10.1016/j.revpalbo.2005.04.001.

Falcon-Lang, H.J. \& DiMichele, W.A. 2010. What happened to the coal forests during Pennsylvanian glacial phases? Palaios, 25, 611-617; doi:10.2110/palo.2009.p09-162r.

Falcon-Lang H.J., Nelson, W.J., Elrick, S., Looy, C.V., Ames, P.R. \& DiMichele, W.A. 2009. Incised channel fills containing conifers indicate that seasonally dry vegetation dominated Pennsylvanian tropical lowlands. Geology, 37, 923-926; doi:10.1130/G30117A.1.

Fielding, C.R., Frank, T.D. \& Isbell, J.L. 2008. The Late Paleozoic ice age - A review of current understanding and synthesis of global climate patterns. Geological Society of America Special Papers, 441, 343-354; doi:10.1130/2008.2441(24).

Fielding, C.R., Allen, J.P., Alexander, J. \& Gibling, M.R. 2009. Facies model for fluvial systems in the seasonal tropics and subtropics. Geology, 37, 623-626; doi:10.1130/ G25727A.1.

Florin, R. 1934. Zur Kenntnis der paläozoischen Pflanzengattungen Lesleya Lesquereux und Megalopteris Dawson. Arkiv för Botanik (Kungliga Svenska Vetenskapsakademien), 25A (4), 19, 1-23.

Gastaldo, R.A. \& Degges, C.W. 2007. Sedimentology and paleontology of a Carboniferous log jam. International Journal of Coal Geology, 69, 103-118; doi:10.1016/j. coal.2006.02.011.

Gastaldo, R.A. \& Demko, T.M. 2011. Long term hydrology controls the plant fossil record. In: Taphonomy: processes and bias through time (eds. Allison, P.A. \& Bottjer, D.J.). Topics in Geobiology, 32, 249-286.

Gastaldo, R.A, DiMichele, W.A. \& Pfefferkorn, H.W. 1996. Out of the icehouse into the greenhouse - A late Paleozoic analog for modern global vegetational change. GSA Today, 6 (10), 1-7.

Grady, W.C., Eble, C.F. \& Ashton, K.C. 1992. Coal supplies for the 1990's: a re-evaluation of Kanawha Formation splint coals in central and southern West Virginia. In: New Perspectives on Central Appalachian Low Sulfur Coal Supplies (eds. Platt, J., Price, J., Miller, M. \& Suboleski, S.). Coal Decisions Forum Publication, TechBooks, 77-101.

Greb, S.F., Andrews, W.M., Eble, C.F., DiMichele, W.A., Cecil, C.B. \& Hower, J.C. 2003. Desmoinesian coal beds of the Eastern Interior and surrounding basins: The largest tropical peat mires in Earth history. In: Extreme Depositional Environments: Mega-end Members in Geologic Time (eds. Chan, M.A. \& Archer, A.W.). Geological Society of America Special Papers, 370, 127-150.

Grebe, H. 1972. Die Verbreitung der Mikrosporen im Ruhrkarbon von den Bochumer Schichten bis zu den Dorstener Schichten (Westphalian A-C). Palaeontographica, Abt. B, 140, 27-115.
Harms, V.L. \& Leisman, G.A. 1961. The anatomy and morphology of certain Cordaites leaves. Journal of Paleontology, 35, 1041-1064.

Hawkins, K., Davies, S.J. Mullins, G.L. \& Macquaker, J.H.S. 2013. Miospore distribution and sedimentological facies distribution as an insight to changing terrestrial palaeoequatorial floral communities during a Pennsylvanian glacio-eustatic sea level cycle. Review of Palaeobotany and Palynology, 197, 166-178; doi:10.1016/j.revpalbo.2013.05.002.

Heckel, P.H. 2008. Pennsylvanian cyclothems in Midcontinent North America as far-field effects of waxing and waning of Gondwana ice sheets. Geological Society of America Special Papers, 441, 275-289.

Hoof, T.B. van, Falcon-Lang, H.J., Hartkopf-Fröder, C. \& Kerp, H. 2013. Conifer-dominated palynofloras in the Middle Pennsylvanian strata of the De Lutte-6 borehole, The Netherlands: Implications for evolution, palaeoecology and biostratigraphy. Review of Palaeobotany and Palynology, 188, 18-37; doi:10.1016/j. revpalbo.2012.09.003.

Horton, D.E., Poulsen, C.J., Montañez, I.P. \& DiMichele, W.A. 2012. Eccentricity-paced late Paleozoic climate change. Palaeogeography, Palaeoclimatology, Palaeoecology, 331, 150-161; doi:10.1016/j.palaeo.2012.03.014.

Hower, J.C., Eble, C.F. \& Pierce, B.S. 1996. Petrography, geochemistry and palynology of the Stockton coal bed (Middle Pennsylvanian), Martin County, Kentucky. International Journal of Coal Geology, 31, 195-215; doi:10.1016/S0166-5162(96)00017-1.

Jasper, K., Hartkopf-Fröder, C., Flajs, G. \& Littke, R. 2010a. Palaeoecological evolution of Duckmantian wetlands in the Ruhr Basin (western Germany): A palynological and coal petrographical analysis. Review of Palaeobotany and Palynology, 162, 123-145; doi:10.1016/j.revpalbo.2010.06.009.

Jasper, K., Hartkopf-Fröder, C., Flajs, G. \& Littke, R. 2010b. Evolution of Pennsylvanian (Late Carboniferous) peat swamps of the Ruhr Basin, Germany: Comparison of palynological, coal petrographical and organic geochemical data. International Journal of Coal Geology, 83, 346-365; doi:10.1016/j.coal.2010.05.008.

Jennings, J.R. \& Eggert, D.A. 1977. Preliminary report on permineralized Senftenbergia from the Chester Series of Illinois. Review of Palaeobotany and Palynology, 24, 221-225; doi:10.1016/0034-6667(77)90035-5.

King, S.C., Cleal, C.J. \& Hilton, J. 2011. Common ground between two British Pennsylvanian wetland floras: Using large, first-hand datasets to assess utility of historical museum collections. Palaeogeography, Palaeoclimatology, Palaeoecology, 308, 405-417; doi:10.1016/j.palaeo.2011.05.048.

Kosanke, R.M. \& Cecil, C.B. 1996. Late Pennsylvanian climate changes and palynomorph extinctions. Review of Palaeobotany and Palynology, 90, 113-140; doi:10.1016/0034-6667(95)00027-5.

Laar, J.G.M. van de \& Fremont, W.J.J. 1990. Westphalian palynology of The Netherlands based on six continuously 
cored boreholes. Review of Palaeobotany and Palynology, 65, 275-285; doi:10.1016/0034-6667(90)90077-V.

Lamboy, W. \& Lesnikowska, A. 1988. Some statistical methods useful in the analysis of plant paleoecological data. Palaios, 3, 86-94; doi:10.2307/3514546.

Leary, R.L. 1990. Possible Early Pennsylvanian ancestor of the cycadales. Science, 249, 1152-1154.

Leary, R.L. 1998. Venation patterns in some early Glossopteris. The Palaeobotanist, 47, 16-19.

Leary, R.L. \& Pfefferkorn, H.W. 1977. An Early Pennsylvanian flora with Megalopteris and Noeggerathiales from westcentral Illinois. Illinois State Geological Survey, Circular $500,1-77$.

Libertín, M., Dašková, J., Opluštil, S., Bek, J. \& Edress, N. 2009. A palaeoecological model for a vegetated early Westphalian intramontane valley (Intra-Sudetic Basin, Czech Republic). Review of Palaeobotany and Palynology, 155, 175-203; doi:10.1016/j. revpalbo.2008.07.002.

Loboziak, S. 1974. Considérations palynologiques sur le Westphalien d'Europe occidentale. Review of Palaeobotany and Palynology, 18, 271-289; doi:10.1016/00346667(74)90020-7.

Loon, A.J. van 1971. The stratigraphy of the Westphalian C around Prioro (Prov. León, Spain). (With a palaeontological note: Drifted plant remains by R.H. Wagner). Trabajos de Geologia, 3, 257-263.

Looy, C.V. \& Hotton, C.L. 2014. Spatiotemporal relationships among Late Pennsylvanian plant assemblages: Palynological evidence from the Markley Formation, West Texas, U.S.A. Review of Palaeobotany and Palynology, 211, 10-27; doi:10.1016/j.revpalbo.2014.09.007.

Looy, C.V., Kerp, H., Duijnstee, I.A.P. \& DiMichele, W.A. 2014a. The late Paleozoic ecological-evolutionary laboratory, a land-plant fossil record perspective. The Sedimentary Record, 12 (4), 3-10.

Looy, C.V., Stevenson, R.A., Hoof, T.B. van \& Mander, L. 2014b. Evidence for coal forest refugia in the seasonally dry Pennsylvanian tropical lowlands of the Illinois Basin, USA. PeerJ; doi:10.7717/peerj.630.

Lucas, S.G., Allen, B.D., Krainer, K., Barrick, J., Vachard, D., Schneider, J.W., DiMichele, W.A. \& Bashforth, A.R. 2011. Precise age and biostratigraphic significance of the Kinney Brick Quarry Lagerstätte, Pennsylvanian of New Mexico, USA. Stratigraphy, 8, 7-27.

Lucas, S.G., Nelson, W.J., DiMichele, W.A., Krainer, K., Barrick, J.E., Voigt, S., Chaney, D.S., Elrick, S. \& Spielmann, J.A. 2013. Field guide to the CarboniferousPermian transition in the Cerros de Amado and vicinity, Socorro County, Central New Mexico. In: The Carboniferous-Permian Transition in Central New Mexico (eds. Lucas, S.G., Nelson, W.J., DiMichele, W.A., Spielmann, J.A., Krainer, K., Barrick, J.E., Elrick, S. \& Voigt, S). New Mexico Museum of Natural History and Science Bulletin, 59, 39-76.

Lyons, P.C. \& Darrah, W.C. 1989. Earliest conifers of North America: upland and/or paleoclimatic indicators? Palaios, 4, 480-486; doi:10.2307/3514592.
Mamay, S.H. 1992. Sphenopteridium and Telangiopsis in a Diplopteridium-like association from the Virgilian (Upper Pennsylvanian) of New Mexico. American Journal of Botany, 79, 1092-1101.

Mander, L., Kürschner, W.M. \& McElwain, J.C. 2010. An explanation for conflicting records of Triassic-Jurassic plant diversity. Proceedings of the National Academy of Sciences of the United States of America, 107, 5351-5356; doi:10.1073/pnas.1004207107.

Mastalerz, M., Ames, P.R. \& Padgett, P.L. 2003. Coals of the Brazil Formation (Pennsylvanian) in Indiana: observations of correlation inconsistencies and their implications. International Journal of Coal Geology, 54, 209-222; doi:10.1016/S0166-5162(03)00037-5.

Miall, A. 2014. The emptiness of the stratigraphic record: A preliminary evaluation of missing time in the Mesaverde Group, Book Cliffs, Utah, USA. Journal of Sedimentary Research, 84, 457-469; doi:10.2110/jsr.2014.40.

Moore, L.C., Wittry, J. \& DiMichele, W.A. 2014. The Okmulgee, Oklahoma fossil flora, a Mazon Creek equivalent: spatial conservatism in the composition of Middle Pennsylvanian wetland vegetation over $1100 \mathrm{~km}$. Review of Palaeobotany and Palynology, 200, 24-52; doi:10.1016/j.revpalbo.2013.08.002.

Němejc, F. 1968. Paleobotanika III. Systematická Čast. Rostliny Nahosemenné. Nakladatelství Československé Akademie Věd, Praha, 1-478 (in Czech).

Neuzil, S.G., Dulong, F.T. \& Cecil, C.B. 2005. Spatial trends in ash yield, selenium, and other selected trace element concentrations in coal beds of the Appalachian Plateau region, U.S.A. United States Geological Survey Open-File Report 2005-1330; http://pubs.usgs.gov/of/2005/1330/ index.html.

Opluštil, S. \& Cleal, C.J. 2007. A comparative analysis of some Late Carboniferous basins of Variscan Europe. Geological Magazine, 144, 417-448.

Opluštil, S., Pšenička, J., Libertín, M. \& Šimůnek, Z. 2007. Vegetation patterns of Westphalian and Lower Stephanian mire assemblages preserved in tuff beds of the continental basins of Czech Republic. Review of Palaeobotany and Palynology, 143, 107-154; doi:10.1016/j.revpalbo.2006.06.004.

Opluštil, S., Pšenička, J., Libertín, M., Bashforth, A.R., Šimůnek, Z., Drábková, J. \& Dašková, J. 2009a. A Middle Pennsylvanian (Bolsovian) peat-forming forest preserved in situ in volcanic ash of the Whetstone Horizon in the Radnice Basin, Czech Republic. Review of Palaeobotany and Palynology, 155, 234-274; doi:10.1016/j.revpalbo.2009.03.002.

Opluštil, S., Pšenička, J., Libertín, M., Bek, J., Dašková, J., Šimůnek, Z. \& Drábková, J. 2009b. Composition and structure of an in situ Middle Pennsylvanian peat-forming plant assemblage buried in volcanic ash, Radnice Basin (Czech Republic). Palaios, 24, 726-746; doi:10.2110/ palo.2008.p08-128r.

Owens, B., Loboziak, S. \& Teteriuk, V.K. 1978. Palynological subdivision of the Dinantian to Westphalian deposits of northwest Europe, and the Donetz Basin of the U.S.S.R. Palynology, 2, 69-91. 
Pendleton, J.L. \& Wellman, C.H. 2013. Pennsylvanian (midBolsovian to Asturian) megaspores and large pollen of the Bristol Coalfield, UK. Journal of Micropalaeontology, 32, 87-106; doi:10.1144/jmpaleo2012-001.

Peppers, R.A. 1985. Comparison of miospore assemblages in the Pennsylvanian System of the Illinois Basin with those in the Upper Carboniferous of Western Europe. Compte Rendu Neuvième Congrès International de Stratigraphie et de Géologie du Carbonifère, Champaign-Urbana 1979, 2, 483-502.

Peppers, R.A. 1993. Palynological correlation of the Lewisport coal bed (early Desmoinesian) and equivalent coals in the Illinois basin. Illinois State Geological Survey, 1-65 (unpublished manuscript).

Peppers, R.A. 1996. Palynological correlation of major Pennsylvanian (Middle and Upper Carboniferous) chronostratigraphic boundaries in the Illinois and other coal basins. Geological Society of America Memoirs, 188, 1-111.

Peppers, R.A. 1997. Palynology of the Lost Branch Formation of Kansas-new insights on the major floral transition at the Middle-Upper Pennsylvanian boundary. Review of Palaeobotany and Palynology, 98, 223-246; doi:10.1016/ S0034-6667(97)00013-4.

Peyser, C.E. \& Poulsen, C.J. 2008. Controls on PermoCarboniferous precipitation over tropical Pangaea: a GCM sensitivity study. Palaeogeography, Palaeoclimatology, Palaeoecology, 268, 181-192; doi:10.1016/j. palaeo.2008.03.048.

Pfefferkorn, H.W. 1979. High diversity and stratigraphic age of the Mazon Creek flora. In: Mazon Creek Fossils (ed. Nitecki, M.H.). Academic Press, New York, 129-142.

Pfefferkorn, H.W. 1980. A note on the term "upland flora". Review of Palaeobotany and Palynology, 30, 157-158.

Pfefferkorn, H. 1995. We are temperate climate chauvinists. Palaios, 10, 389-391.

Pfefferkorn, H.W. \& Resnik, D.A. 1980. The occurrence of Sphenopteris germanica (pteridosperm, Autunian, Lower Permian) in North America. Journal of Paleontology, 54, 81-84.

Pfefferkorn, H.W. \& Thomson, M.C. 1982. Changes in dominance patterns in upper Carboniferous plant-fossil assemblages. Geology, 10, 641-644; doi:10.1130/00917613(1982) $0<641:$ CIDPIU> 2.0.CO;2.

Pfefferkorn, H.W., Mustafa, H. \& Hass, H. 1975. Quantitative Charakterisierung ober-karboner Abdruckfloren (Quantitative characterization of compression-impression floras of Upper Carboniferous age). Neues Jahrbuch für Geologie und Paläontologie, Abhandlungen 150, 253-269.

Phillips, T.L. \& Galtier, J. 2005. Evolutionary and ecological perspectives of Late Paleozoic ferns: Part I. Zygopteridales. Review of Palaeobotany and Palynology, 135, 165-203; doi:10.1016/j.revpalbo.2005.03.006.

Phillips, T.L., Peppers, R.A. \& DiMichele, W.A. 1985. Stratigraphic and interregional changes in Pennsylvanian coal-swamp vegetation: Environmental inferences. International Journal of Coal Geology, 5, 43-109.

Phillips, T.L., Peppers, R.A., Avcin, M.J. \& Laughnan, P.F. 1974. Fossil plants and coal: patterns of change in
Pennsylvanian coal swamps of the Illinois Basin. Science, 184, 1367-1369.

Pierce, B.S., Stanton, R.W. \& Eble, C.F. 1991. Facies development in the Lower Freeport coal bed, westcentral Pennsylvania, USA. International Journal of Coal Geology, 18, 17-43; doi:10.1016/0166-5162(91)90042-H.

Pierce, B.S., Stanton, R.W. \& Eble, C.F. 1993. Comparison of the petrography, palynology and paleobotany of the Stockton coal bed, West Virginia and implications for paleoenvironmental interpretations. Organic Geochemistry, 20, 149-166; doi:10.1016/0146-6380(93)90034-9.

Plotnick, R.E., Kenig, F., Scott, A.C., Glasspool, I.J., Eble, C.F. \& Lang, W.J. 2009. Pennsylvanian paleokarst and cave fills from northern Illinois, USA: a window into late Carboniferous environments and landscapes. Palaios, 24, 627-637.

Raymond, A. 1988. The paleoecology of a coal-ball deposit from the Middle Pennsylvanian of Iowa dominated by cordaitalean gymnosperms. Review of Palaeobotany and Palynology, 53, 233-250; doi:10.1016/00346667(88)90034-6.

Raymond, A. \& Costanza, S. 2007. Are wind-pollinated less diverse and longer ranging than insect-pollinated groups? Geological Society of America, Abstracts with Program, 39, 565.

Raymond, A., Wehner, M. \& Costanza, S.H. 2014. Permineralized Alethopteris ambigua (Lesquereux) White: A medullosan with relatively long-lived leaves, adapted for sunny habitats in mires and floodplains. Review of Palaeobotany and Palynology, 200, 82-96; doi:10.1016/j. revpalbo.2013.07.001.

Raymond, A., Lambert, L., Costanza, S., Slone, E.J. \& Cutlip, P.C. 2010. Cordaiteans in paleotropical wetlands: An ecological re-evaluation. International Journal of Coal Geology, 83, 248-265; doi:10.1016/j.coal.2009.10.009.

Remy, W. 1978. Die Sphenopteris germanica-Gruppe in den "Süplinger Schichten", Flechtinger Höhenzug. Ein Bele für das Autun-Alter. Argumenta Palaeobotanica, 5, 161-165.

Remy, W. \& Remy, R. 1975. Beiträge zur Kenntnis des Morpho-Genus Taeniopteris Brongniart. Argumenta Palaeobotanica, 4, 31-37.

Remy, W. \& Remy, R. 1978. Beiträge zur Flora des Stefans und Autuns. Argumenta Palaeobotanica, 5, 195-204.

Remy, W. \& Rettschlag, R. 1954. Neue Untersuchungen über die Pollen von Schuetzia anomala H. B. Geinitz. Geologie, 3, 582-589.

Rosenau, N.A., Tabor, N.J., Elrick, S.D. \& Nelson, W.J. 2013a. Polygenetic history of paleosols in middle-upper Pennsylvanian cyclothems of the Illinois basin, USA: Part I. Characterization of paleosol types and interpretation of pedogenic processes. Journal of Sedimentary Research, 83, 606-636.

Rosenau, N.A., Tabor, N.J., Elrick, S.D. \& Nelson, W.J. 2013b. Polygenetic history of paleosols in middle-upper Pennsylvanian cyclothems of the Illinois basin, USA: Part II. Integrating geomorphology, climate, and glacioeustasy. Journal of Sedimentary Research, 83, 637-668. 
Rößler, R. 2006. Two remarkable Permian petrified forests: correlation, comparison and significance. Geological Society London, Special Publications, 265, 39-63.

Rößler, R. \& Noll, R. 2006. Sphenopsids of the Permian (I): The largest known anatomically preserved calamite, an exceptional find from the petrified forest of Chemnitz, Germany. Review of Palaeobotany and Palynology, 140, 145-162; doi:10.1016/j.revpalbo.2006.03.008.

Rothwell, G.W. \& Warner, S. 1984. Cordaixylon dumusum n. sp. (Cordaitales). I. Vegetative structures. Botanical Gazette, 145, 275-291.

Royer, D.L., Sack, L., Wilf, P., Lusk, C.H., Jordan, G.J., Niinemets, Ü., Wright, I.J., Westoby, M., Cariglino, B., Coley, P.D., Cutter, A.D., Johnson, K.R., Labandeira, C.C., Moles, A.T., Palmer, M.B. \& Valladares, F. 2007. Fossil leaf economics quantified: calibration, Eocene case study, and implications. Paleobiology, 33, 574-589.

Scheihing, M.H. 1980. Reduction of wind velocity by the forest canopy and the rarity of non-arborescent plants in the Upper Carboniferous fossil record. Argumenta Palaeobotanica, 6, 133-138.

Scott, A.C. \& Stephens, R.S. 2014. British Pennsylvanian (Carboniferous) coal-bearing sequences: where is the time? Geological Society, London, Special Publications, 404, 283-302; doi:10.1144/SP404.14.

Šimůnek, Z. 2000. Cuticles of Cordaites from the Westphalian, Stephanian and Autunian of the Bohemian Massif (Czech Republic) (a preliminary study). Acta Palaeobotanica, 40, 25-34.

Šimůnek, Z. 2007. New classification of the genus Cordaites from the Carboniferous and Permian of the Bohemian Massif based on micromorphology of its cuticle. Acta Musei Nationalis Pragae, Series B, Historia Naturalis, 62 (3-4), 97-210.

Šimůnek, Z. 2008. The Asturian and Cantabrian floral assemblages with Cordaites from the Plzeň Basin (Czech Republic). Studia Geologica Polonica, 129, 51-80.

Šimůnek, Z. \& Florjan, S. 2013. The Pennsylvanian cordaitalean dispersed cuticles from the Upper Silesian Basin (Poland). Review of Palaeobotany and Palynology, 197, 26-49; doi:10.1016/j.revpalbo.2013.04.006.

Šimůnek, Z. \& Libertín, M. 2006. Cordaites schatzlarensis sp. nov. and Samaropsis newberryi (Andrews) Seward from the Westphalian (Carboniferous) of the Žaclér area (Czech Republic). Review of Palaeobotany and Palynology, 138, 43-62; doi:10.1016/j.revpalbo.2005.10.001.

Šimůnek, Z., Opluštil, S. \& Drábková, J. 2009. Cordaites borassifolius (Sternberg) Unger (Cordaitales) from the Radnice Basin (Bolsovian, Czech Republic). Bulletin of Geosciences, 84, 301-336.

Smith, A.H.V. \& Butterworth, M.A. 1967. Miospores in the coal seams of the Carboniferous of Great Britain. Special Papers in Palaeontology, 1, 1-324.

Stull, G.W., DiMichele, W.A., Falcon-Lang, H.J., Nelson, W.J. \& Elrick, S. 2012. Palaeoecology of Macroneuropteris scheuchzeri, and its implications for resolving the paradox of 'xeromorphic' plants in Pennsylvanian wetlands. Palaeogeography, Palaeoclimatology, Palaeoecology, 331-332, 162-176; doi:10.1016/j.palaeo.2012.03.019.
Tabor, N.J. \& Poulsen, C.J. 2008. Palaeoclimate across the Late Pennsylvanian-Early Permian tropical palaeolatitudes: A review of climate indicators, their distribution, and relation to palaeophysiographic climate factors. Palaeogeography, Palaeoclimatology, Palaeoecology, 268, 293-310; doi:10.1016/j.palaeo.2008.03.052.

Tabor, N.J., DiMichele, W.A., Montañez, I.P. \& Chaney, D.S. 2013a. Late Paleozoic continental warming of a cold tropical basin and floristic change in western Pangea. International Journal of Coal Geology, 119, 177-186; doi:10.1016/j.coal.2013.07.009.

Tabor, N.J., Romanchock, C.M., Looy, C.V., Hotton, C.L., DiMichele, W.A. \& Chaney, D.S. 2013b. Conservatism of Late Pennsylvanian vegetational patterns during shortterm cyclic and long-term directional environmental change, western equatorial Pangea. Geological Society, London, Special Publications, 376, 201-234.

Trivett, M.L. \& Rothwell, G.W. 1985. Morphology, systematics, and paleoecology of Paleozoic fossil plants: Mesoxylon priapi, sp. nov. (Cordaitales). Systematic Botany, 10, 205-223.

Wagner, R.H. 1958. Some Stephanian pecopterids from NW. Spain. Mededelingen Geologische Stichting, Nieuwe Serie, 12, 5-23.

Wagner, R.H. 1984. Megafloral zones of the Carboniferous. Compte Rendu Neuvième Congrès International de Stratigraphie et de Géologie du Carbonifère, ChampaignUrbana 1979, 2, 109-134.

Wagner, R.H. 2001. The extrabasinal elements in lower Pennsylvanian floras on the Maritime Provinces, Canada: description of Adiantites, Pseudadiantites and Rhacopteridium. Revista Española de Paleontología, 16, 187-207.

Wagner, R.H. 2004. Climatic changes as mirrored by Carboniferous and Permian floral distribution. Monografias del Jardín Botánico de Córdoba, 11, 29-39.

Wagner, R.H. \& Álvarez-Vázquez, C. 2010. The Carboniferous floras of the Iberian Peninsula: a synthesis with geological connotations. Review of Palaeobotany and Palynology, 162, 239-324; doi:10.1016/j.revpalbo.2010.06.005.

Wagner, R.H. \& Castro, M.P. 2011. Compositional changes in a mid-Stephanian (Kasimovian) flora in relation to alluvial plain deposits derived from westward-receding mountains and bordered by the Paleotethys: La Magdalena Coalfield, northwestern Spain. Palaios, 26, 33-54.

Watney, W.L., Wong, J.-C. \& French, J.A. 1989. Computer simulation of Upper Pennsylvanian (Missourian) carbonate-dominated cycles in western Kansas. In: Sedimentary Modeling: Computer Simulations and Methods for Improved Parameter Definition (eds. Franseen, E.K., Watney, W.L., Kendall, C.G.S. \& Ross, W.). Kansas Geological Survey Bulletin, 233, 415-430.

Willard, D.A. 1993. Vegetational patterns in the Springfield coal (Middle Pennsylvanian, Illinois Basin): comparison of miospore and coal-ball records. Geological Society of America Special Papers, 286, 139-152.

Wing, S.L. \& DiMichele, W.A. 1995. Conflict between local and global changes in plant diversity through geological time. Palaios, 10, 551-564. 
Wittry, J., Glasspool, I.J., Béthoux, O., Koll, R. \& Cleal, C.J. 2014. A revision of the Pennsylvanian marattialean fern Lobatopteris vestita auct. and related species. Journal of Systematic Palaeontology, 2014; doi:10.1080/14772019. 2014.936915.

Wright, I.J., Reich, P.B., Westoby, M., Ackerly, D.D., Baruch, Z., Bongers, F., Cavender-Bares, J., Chapin, T., Cornelissen, J.H.C., Diemer, M., Flexas, J., Garnier, E., Groom, P.K., Gulias, J., Hikosaka, K., Lamont, B.B., Lee, T., Lee, W., Lusk, C., Midgley, J.J., Navas, M.-L., Niinemets, Ü., Oleksyn, J., Osada, N., Poorter, H., Poot, P., Prior, L., Pyankov, V.I., Roumet, C., Thomas, S.C., Tjoelker, M.G., Veneklaas, E.J. \& Villar, R. 2004. The worldwide leaf economics spectrum. Nature, 428, 821827; doi:10.1038/nature02403.
Zodrow, E.L. \& Cleal, C.J. 1993. The epidermal structure of the Carboniferous gymnosperm frond Reticulopteris. Palaeontology, 36, 65-79.

Zodrow, E.L., Šimůnek, Z. \& Bashforth, A.R. 2000. New cuticular morphotypes of Cordaites principalis from the Canadian Carboniferous Maritimes Basin. Canadian Journal of Botany, 78, 135-148; doi:10.1139/b00-010.

Zodrow, E.L., Mastalerz, M. \& Šimůnek, Z. 2003. FTIRderived characteristics of fossil-gymnosperm leaf remains of Cordaites principalis and Cordaites borassifolius (Pennsylvanian, Maritimes Canada and Czech Republic). International Journal of Coal Geology, 55, 95-102; doi:10.1016/S0166-5162(03)00084-3. 